\title{
THE PHYTOPLANKTON OF FREMONT LAKE,
}

\section{WYOMING}

by Robert C. Averett, William W. Emmett, and David A. Peterson

\section{U.S. GEOLOGICAL SURVEY}

Water-Resources Investigations Report 92-4071

Prepared in cooperation with the TOWN OF PINEDALE, WYOMING

Dedication: This report is dedicated with respect and admiration to the memory of Robert C. Averett

(October 3, 1930 - June 25, 1993)

Denver, Colorado

1993

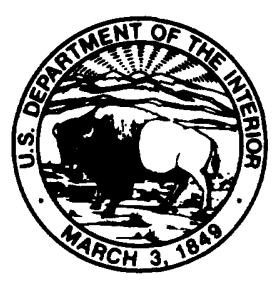




\section{U.S. DEPARTMENT OF THE INTERIOR \\ BRUCE BABBITT, Secretary}

U.S. GEOLOGICAL SURVEY

Dallas L. Peck, Director

The use of trade, product, industry, or firm names is for descriptive purposes only and does not imply endorsement by the U.S. Government.

For additional information write to: Chief, Branch of Regional Research U.S. Geological Survey

Box 25046, Mail Stop 418

Federal Center

Denver, CO 80225-0046
Copies of this report can be purchased from:

U.S. Geological Survey

Books and Open-File Reports Section

Box 25425, Mail Stop 517

Federal Center

Denver, CO 80225-0425 


\section{CONTENTS}

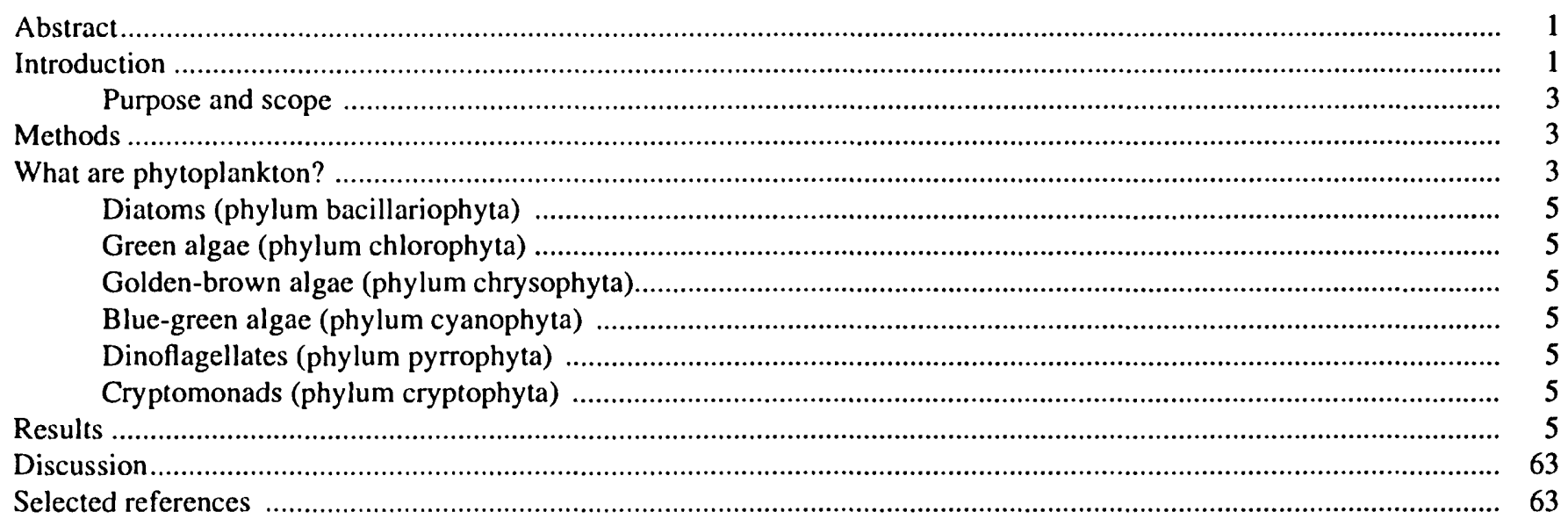

\section{FIGURES}

1. Map showing bathymetry of Fremont Lake

2. Photographs showing typical views of Fremont Lake

3-5. Graphs showing:

3. Depth profiles of temperature, specific conductance, dissolved oxygen, and $\mathrm{pH}$ for 1984 (site 1), and temperature for 1989 (site 3)

4. Average phytoplankton concentrations from water surface to 24-m depth and Secchi-disk depths (site 1), 1983-84 sampling dates

5. Average phytoplankton concentrations from water surface to lake bottom at site 3,1989 sampling dates

\section{TABLES}

1. Phytoplankton concentrations from site $1,1983-84$

2. Phytoplankton concentrations from site 3,1989 ..

3. Presence or absence of phytoplankton genera, 1983-84 and 1989

4. Presence or absence of representative taste and odor phytoplankton genera, 1983-84 and 1989 


\begin{tabular}{rll}
\hline Multiply & By & To obtain \\
\hline cubic meter per second $\left(\mathrm{m}^{3} / \mathrm{s}\right)$ & 35.31 & cubic foot per second \\
kilometer $(\mathrm{km})$ & 0.6214 & mile \\
$\operatorname{liter}(\mathrm{L})$ & 0.2642 & gallon \\
$\operatorname{meter}(\mathrm{m})$ & 3.281 & feet \\
square kilometer $\left(\mathrm{km}^{2}\right)$ & 0.3861 & square mile \\
\hline
\end{tabular}

To convert degree Celsius $\left({ }^{\circ} \mathrm{C}\right)$ to degree Fahrenheit $\left({ }^{\circ} \mathrm{F}\right)$, use the following formula:

$$
{ }^{\circ} \mathrm{F}=9 / 5\left({ }^{\circ} \mathrm{C}\right)+32 .
$$

The following terms and abbreviations also are used in this report:

cell per milliliter (cell/mL)

microsiemens per centimeter at 25 degrees Celsius $(\mu \mathrm{S} / \mathrm{cm})$

milligram per liter $(\mathrm{mg} / \mathrm{L})$

Sea level: In this report "sea level" refers to the National Geodetic Vertical Datum of 1929 (NGVD of 1929)--a geodetic datum derived from a general adjustment of the first-order level nets of both the United States and Canada, formerly called Sea Level Datum of 1929. 


\title{
THE PHYTOPLANKTON OF FREMONT LAKE, WYOMING
}

\author{
ByRobert C. Averett, William W. Emmett, andDavid A. Peterson
}

\section{Abstract}

Fremont Lake is a large (surface area about 20.6 square kilometers), deep (about 185 meters), high-altitude (2,261 meters above sea level) lake in western Wyoming. The lake is a dilute system with a dissolved-solids concentration of about 13 milligrams per liter and nitrogen and phosphorus concentrations less than analytical detection. The mean silica concentration is about 1.4 milligrams per liter and varies little with season. Dissolved organic carbon is about 1 milligram per liter.

The phytoplankton of Fremont Lake was studied in 1983-84 and 1989 at two sites. Six phyla (divisions) of phytoplankton were present in the lake, represented by 146 species. Some viable diatom cells were collected at the 120-meter depth in relatively large concentrations. Whereas the green algae Volvox reached almost 20,000 cells per milliliter in one August sample, most phytoplankton concentrations were low. Blue-green algae were represented by six genera, but concentrations were never at levels indicative of troublesome enrichment problems.

An objective of the sample collection in 1989 was to determine the concentration of potential taste and odor phytoplankton in Fremont Lake, which is the water supply for Pinedale, Wyoming. Twenty-four genera were identified that could cause taste and odor in the lake water; 20 of the genera were present in the 1983-84 samples, and 19 were present in the 1989 samples. Tabellaria was the most consistently identified taste and odor genus collected in the samples.

\section{INTRODUCTION}

Phytoplankton (planktonic algae or floating microscopic plants) often are the major flora of large, deep, coldwater lakes. They account for the major part of photosynthesis and hence primary production of lakes and are at the base of the food web. In most oligotrophic or unenriched lakes a diverse algal flora is present (Lund, 1965). In enriched or eutrophic lakes a few species dominate, often blue-green algae (Cyanophyta) of which some species are capable of obtaining their nitrogen requirements from the atmosphere (Horne, 1977). There often is no clear distinction between oligotrophic and eutrophic lakes; rather, it is a continuum (Carlson, 1977). The term mesotrophic often is used to describe the intermediate stage of enrichment, but it too is only a subjective assessment of enrichment.

The phytoplankton assemblage is one of several indicators of trophic or nutritional status in lakes and often is the most vivid. Shifts in lake trophic status, from oligotrophic to eutrophic, usually are indicated by large increases in the numbers of a few blue-green algal species. When abundant and undergoing profuse production (algal-bloom conditions), some blue-green algae may cause noxious scum on the water, taste and odor problems in the water and in fish, and may be toxic to mammals and fish. Lakes that have profuse algal-production problems often are so enriched that little can be done to mitigate their condition. One goal of lake management is to quantify changes in enrichment so that nutrient-control measures can be employed to prevent excessive algal production.

Most western lakes presently are unenriched, primarily because of relatively low human influence. These lakes are mostly used for recreation, irrigation, and domestic water supply. Few, however, have been studied from a trophic standpoint, one of the goals of our Fremont Lake studies.

Fremont Lake is in northwestern Wyoming at an elevation of about $2,261 \mathrm{~m}$ above sea level and is an oligotrophic system having a surface area of about $20.6 \mathrm{~km}^{2}$ and a maximum depth of a little more than $185 \mathrm{~m}$. The lake has a maximum length of about $15 \mathrm{~km}$ and a maximum width of about $2 \mathrm{~km}$ (fig. 1). Fremont Lake is large by world standards (Wetzel, 1983) and is an important recreation lake. The primary carnivore in the lake is the lake trout or Mackinaw (Salvelinus namaycush), but rainbow trout (Oncorhynchus mykiss) and brook trout (Salvelinus fontinalis) also are present. Fremont Lake is on the west flank of the Wind River Range, and much of the annual precipitation is snow. Formation of the lake was by the damming of a glacial valley by a terminal moraine about 10,000 years ago. The inflow is primarily from Pine Creek on the north, which for the period of record (1954-83) had an annual mean flow of $5.06 \mathrm{~m}^{3} / \mathrm{s}$, with 40 percent of the flow occurring in June (Emmett and Averett, 1989). There are several minor tributaries to Fremont Lake, but they are ungaged and insignificant from a water-source standpoint. 


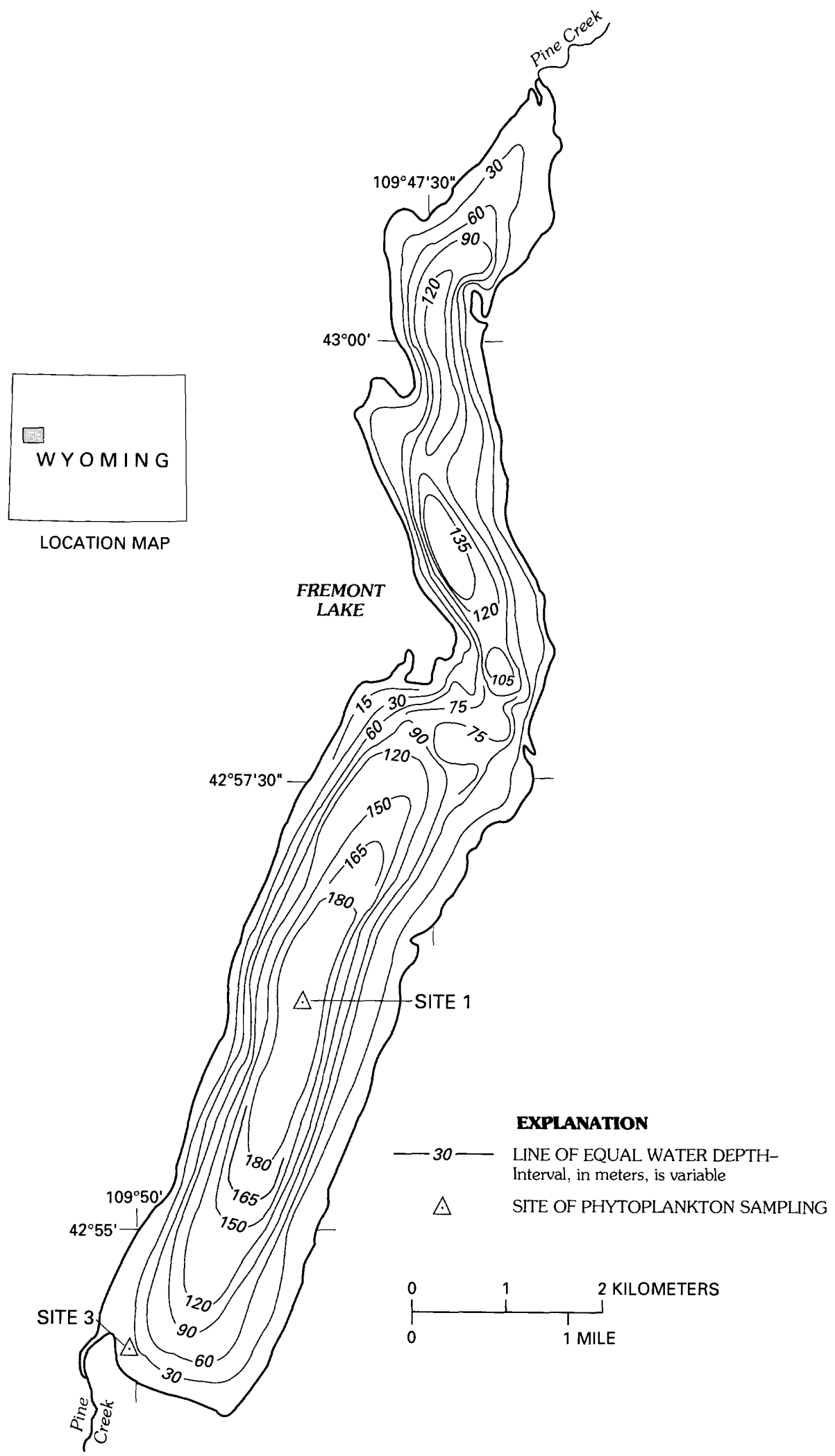

Figure 1. Bathymetry of Fremont Lake (from Emmett and Averett, 1989). 
Fremont Lake is drained from the south by Pine Creek, a tributary to the New Fork River. Typical views of Fremont Lake, looking uplake and downlake, are shown in figure 2. About 42 cabins are located in the Bridger-Teton National Forest on slopes near the midpoint of the eastern side of the lake (Sylvan Bay Summer Home Area), but none are on the shoreline. Sewage disposal by the cabins is mostly with leach fields, but there is no evidence of any leachate reaching the lake. A U.S. Forest Service campground (Fremont Lake Campground) is located along the shore of the lake immediately south of the summer home area. The campground has pit-toilet facilities from which the waste can be transported out of the basin. At the south end of the lake is a small lodge, restaurant, boat moorage facility, and several privately owned cabins along the shoreline of the lake.

Past studies on Fremont Lake are described in Rickert and Leopold (1972), Leopold (1980), Grabowski (1982), Peterson, Averett, and Mora (1987), and Emmett and Averett (1989). These studies have led to a better understanding of the lake and have provided insight to processes underway in the lake. Phytoplankton sample collection was begun in 1983, continued in 1984, and in cooperation with the town of Pinedale was conducted again in 1989. The 1983-84 collections were made to assess the general types and abundance of phytoplankton in the lake. The 1989 collections were done to follow up on the 1983-84 collections as well as to assess potential causes of a taste and odor problem in the Pinedale water supply, which comes from about a 20-m depth near the south end of the lake. Prior to construction of this water-supply inlet in 1970, Pinedale obtained its water from Pine Creek about a kilometer downstream from the Fremont Lake outlet. Taste and odor problems occurred with the creek source, and the water-supply inlet was moved to the present 20-m-depth location in Fremont Lake. This change seemed to solve the taste and odor problem until the late 1980's when it reoccurred between June and September.

\section{Purpose and Scope}

The purpose of this report is to provide information on the phytoplankton (planktonic form of algae) community in Fremont Lake. Samples for identification and concentrations of phytoplankton were collected at two sites during 1983-84 and 1989. The goal was to evaluate the phytoplankton community structure from the standpoint of lake enrichment and to determine the types, location, and relative abundance of potential taste- and odor-causing algae. Although some water samples were analyzed for major ions and trace metals, the scope of this report is limited to nutrient analysis. Depth-profile measurements of water temperature, specific conductance, dissolved oxygen, and $\mathrm{pH}$ also were made in 1984 and water temperature in 1989. Secchi-disk depths were recorded for 1983-84.

\section{METHODS}

Water samples for phytoplankton were collected at predetermined depths with a 2-L Van Dorn or Kemmerer water bottle. In 1983-84, phytoplankton samples were collected at site 1; in 1989, phytoplankton samples were collected at site 3 (fig. 1). Site 2, not shown in figure 1 , was established in 1983-84 for the collection of some water samples for chemical analysis. Water samples were preserved with Lugol's solution or 70 percent ethyl alcohol (Britton and Greeson, 1989). The phytoplankton in the samples were identified to genus, species, and numbers of each by using an inverted microscope. In the identification of algae, there are always some species of which the classification is in doubt. In addition, there are discrepancies in techniques and abilities between persons doing the identification, and identification keys are continually undergoing improvement. Thus, there is always some inaccuracy in identification. In this regard, we have listed the information given by each analyst, realizing there may be some discrepancies. Such discrepancies probably are more pronounced between years of sample collection rather than among samples collected in a given year. Furthermore, those species in which identification errors are most likely to be made are generally few, as well as minor in importance to assessing the water quality of Fremont Lake. Phytoplankton identification did not receive outside verification.

Depth-profile measurements of water temperature, specific conductance, dissolved oxygen, and $\mathrm{pH}$ were measured in 1983-84 using a multiparameter sensor attached to $200 \mathrm{~m}$ of cable. Only water temperature was measured during 1989. Transparency (reported as Secchi-disk depth) was measured during 1983-84 using a black-and-white, 20-cmdiameter Secchi disk. Water for laboratory chemical analysis was collected using a Teflon-coated Van Dorn bottle to avoid metal contamination. Chemical analysis was done at the U.S. Geological Survey National Research Program Laboratory in Arvada, Colorado.

\section{WHAT ARE PHYTOPLANKTON?}

This report is about the phytoplankton (planktonic form of algae) in Fremont Lake. Thus, it is important that some of the terms and types of algae be discussed before presenting the results of the study. A definition of the algae with which this report is concerned is reported by Prescott (1974) and Trainor (1978) as follows: "Algae are photosynthetic, nonvascular plants that contain chlorophyll $a$ and have simple reproductive structures." This simple definition does not consider the size of algae. Most species are much less than a millimeter in diameter, and many are less than a micron. However, some marine forms such as the kelps may be several meters in length. The term phytoplankton (phyto meaning plant and plankton meaning to wander) as used in this report refers to algae in the water column of the lake. Many algae are attached to solid surfaces and are called periphyton (peri meaning around and phyton meaning plant), but in Fremont Lake periphyton are not abundant and probably are a minimal part of the lake flora. The term algae is used in this 


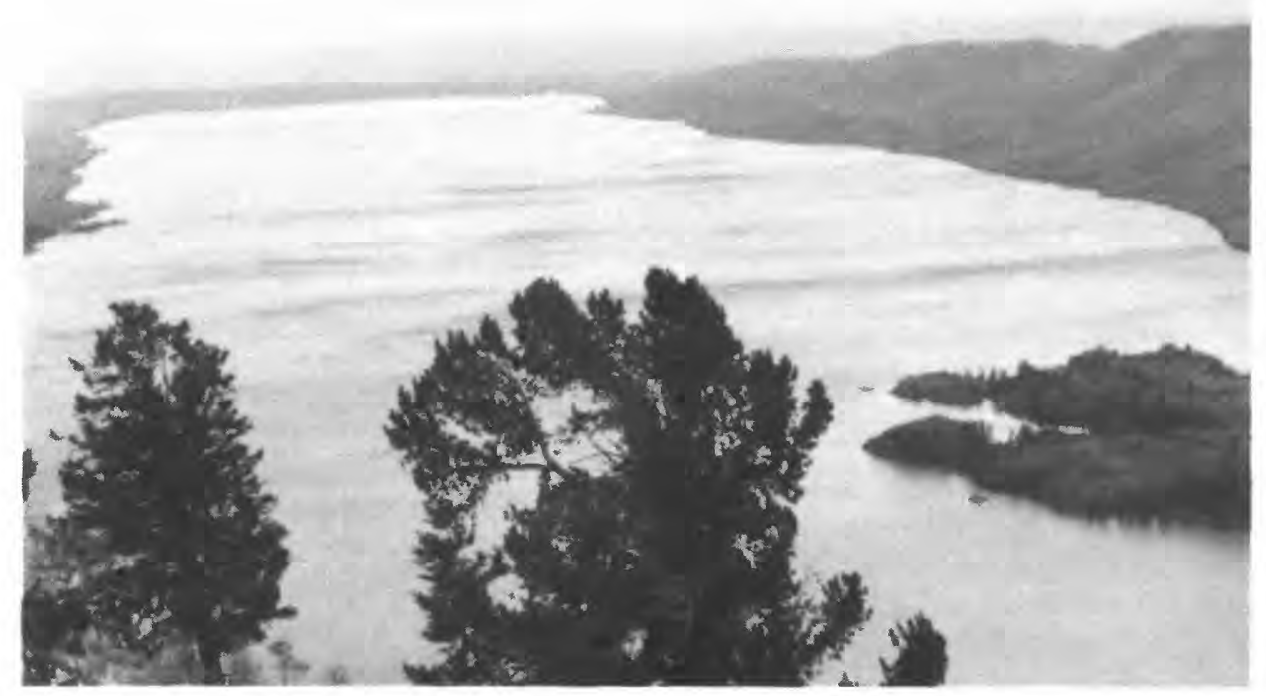

(A) Looking downlake (south) from near the inlet. The lake narrows are formed by the encroaching bedrock visible in the lower right of the photograph; from the narrows to the outlet, the west edge of Fremont Lake is formed by lateral moraine deposits.

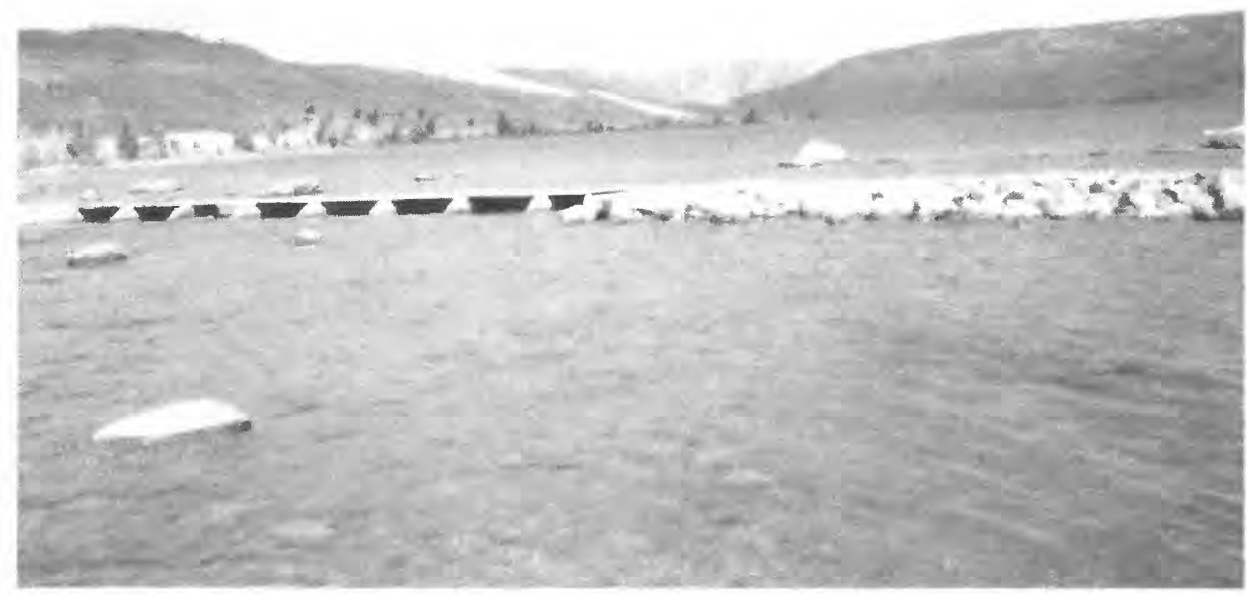

(B) Looking uplake (north) across the low dam constructed in 1934 at the outlet to Pine Creek. The south end of the lake was dammed by terminal moraine deposits; the low man-made dam is less than 2 meters in height. The city water intake is located several hundred meters into the lake from the south shore near the outlet; the location is about the middle right edge of the photograph.

Figure 2. Typical views of Fremont Lake. 
report where appropriate for general discussion, and the term phytoplankton is used for more specific discussion related to the algal community in Fremont Lake. Because algae can carry out photosynthesis, they are at the bottom of the food web in most aquatic environments, including Fremont Lake. All higher life depends upon them as a food source. The algae of Fremont Lake are small (usually less than a micron in diameter), are primarily planktonic, and usually reproduce by simple cell division.

A number of chemical constituents and compounds are required for algal nutrition (growth and reproduction), but most often, phosphorus is the nutrient that is most likely to be in short supply, limiting algal growth. Nitrogen is sometimes limiting, and thus also regulates algal growth, but some blue-green algae can obtain their nitrogen needs from the atmosphere. Silica can be a limiting nutrient for diatoms. Blue-green algae often are the first indicators of excessive nutrient supplies in a lake, and when this occurs they reproduce in excessive numbers, resulting in the water becoming pale green, often with algal scums on the surface.

Several algal classification schemes are in common use. We have used that of Prescott (1974) and Smith (1950) but have placed the diatoms in the phylum (division) Bacillariophyta. This scheme recognizes the six phyla (highest classification) in Fremont Lake. Except for the diatoms, we have listed the phyla followed by genus and species. For the diatoms, the taxonomic order also is given to facilitate recognition in future years.

\section{Diatoms (Phylum Bacillariophyta)}

Diatoms are common algae in running waters, but are ubiquitous in distribution and are widespread in lakes and impoundments. The diatoms may be single celled, colonial, or filamentous. Their cell walls are siliceous and etched with grooves and rows with definite patterns. The cell wall consists of two sections, one forming a cover over the other. The centrales have round, triangular, or oval cells. The pennales are elongated and rod shaped or rectangular. The diatoms contain chlorophylls $a$ and $c$ as well as beta-carotene. Diatoms frequently are the dominant algae in the spring, often growing profusely after icemelt and when the surface waters are still cold.

\section{Green algae (Phylum Chlorophyta)}

Green algae are widespread and one of the most common groups of algae in fresh and marine waters. Like the diatoms they may be single celled, colonial, or filamentous. Many single-celled and colony types are motile. The green algae usually have definite cell walls and contain several pigments such as chlorophyll $a$ and $b$, alpha- and beta-carotenes, and several xanthophylls. The storage product of green algae is starch. Reproduction commonly is by simple cell division.

\section{Golden-brown algae (Phylum Chrysophyta)}

The aquatic forms of the golden-brown algae are present in the colder regions of the world and are associated somewhat with winter periods in warmer water, frequently under ice cover. The golden-brown algae are uncommon in the plankton, but in Fremont Lake the genus Dinobryon often was identified in the samples. Some cells have flagella of unequal length and are motile. The chrysophyta contain chlorophyll $a$ and $b$, beta-carotene, and xanthophyll. Reproduction typically is by simple cell division. Some authors place the diatoms as a subphylum in this phylum.

\section{Blue-green algae (Phylum Cyanophyta)}

Blue-green algae are the simplest and most primitive type of algae, very closely related to the bacteria. Cells lack internal membranes and have bound organelles, and plants may be single celled or colonial and have branched or unbranched filaments. Chlorophyll $a$ is present. Blue-green algae can withstand warmer water, and some genera can obtain nitrogen from the atmosphere. In addition, they have a greater ability to utilize carbonate and bicarbonate than other algal types. Reproduction is by vegetative division. Some blue-green algae such as Microcystis, Anabaena, Aphanizomenon, and perhaps a few others can be toxic when ingested in large enough numbers. Each year there are reports of cattle and other mammals dying from ingesting water containing blue-green algae.

\section{Dinoflagellates (Phylum Pyrrophyta)}

These algae usually are flagellated (motile) or are sessile and singled celled. Cells typically are flattened with transverse constriction or girdle around the cell center. Both flagella originate together in the girdle area and trail the cell during movement. Chlorophyll $a$ and $c$ are present as well as carotene and several xanthophylls. Starch is the storage product.

\section{Cryptomonads (Phylum Cryptophyta)}

Cryptomonads are a small algal group with no common name. They are unattached algae and are motile, having two flagella of equal or unequal length. Cells, often oval and flattened, contain chlorophyll $a$ and $c$ and carotene and xanthophylls.

\section{RESULTS}

Selected in-lake measurements for Fremont Lake made during 1984 at site 1 (fig. 1) are shown in figure 3 . These profiles are typical for a large oligotrophic lake. Summer lake-surface temperatures often are between 15 and 

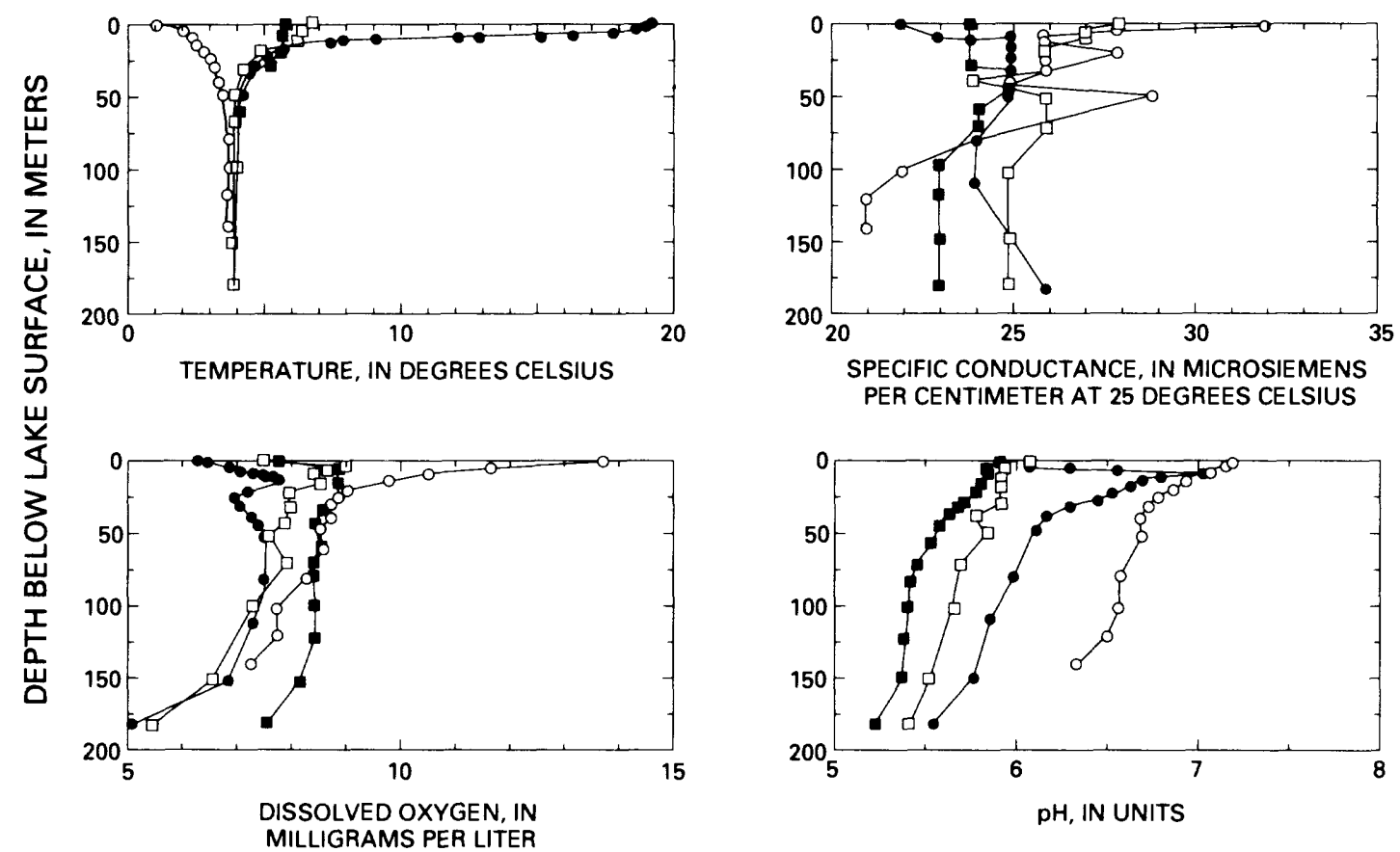

EXPLANATION

- FEBRUARY 22, 1984

व JUNE 9, 1984

- AUGUST 14, 1984

- NOVEMBER 6, 1984

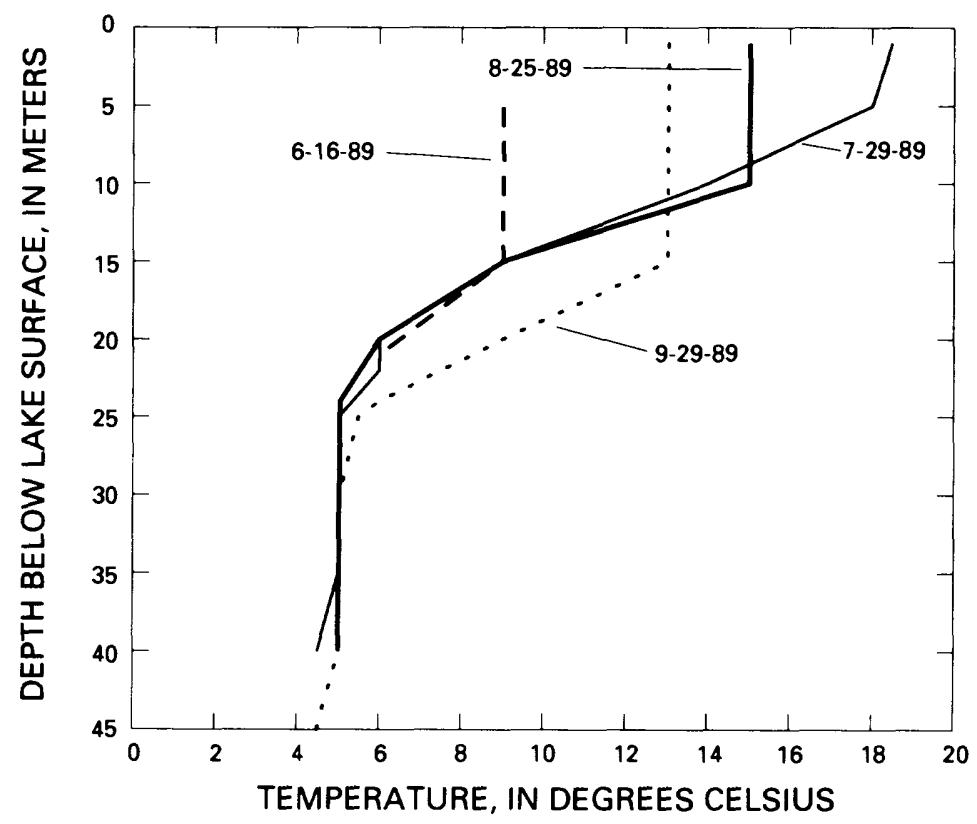

Figure 3. Depth profiles of temperature, specific conductance, dissolved oxygen, and pH for 1984 (site 1), and temperature for 1989 (site 3). 
$20^{\circ} \mathrm{C}$, and the metalimnion is between 10 and $20 \mathrm{~m}$; but with depth, the temperature decreases rapidly. Thermal stratification in Fremont Lake is strong and often extends into November. A typical reverse stratification occurs in the winter under ice cover when the surface water has the lowest temperature. The spring turnover begins at ice breakup, which is usually about May 15 (Leopold, 1980). Specific conductance is low, seldom exceeding $30 \mu \mathrm{S} / \mathrm{cm}$. Because specific conductance is a measure of ions in the water and is related to dissolved solids, the low values indicate the dilute nature of Fremont Lake. Rickert and Leopold (1972) reported the mean dissolved-solids concentration of Fremont Lake as $12.8 \mathrm{mg} / \mathrm{L}$ and listed Fremont Lake as one of the most dilute lakes in the world. The reported dissolved-solids value of $12.8 \mathrm{mg} / \mathrm{L}$ coincides with the mean value of $13 \mathrm{mg} / \mathrm{L}$ reported by Peterson, Averett, and Mora (1987). Dissolved oxygen usually is near saturation. Anoxic conditions in the lake have not been recorded. Most of the $\mathrm{pH}$ values were between 5.5 and 6.5, the expected range. The 1989 late spring and summer temperature profiles at site 3 are shown in the bottom part of figure 3 . Again, strong thermal stratification is evident.

The chemical composition of the water in Fremont Lake is discussed in some detail by Peterson, Averett, and Mora (1987). As expected from the dissolved-solids concentration, most constituent concentrations were low. Of interest from the standpoint of algae are silica, nitrogen, phosphorus, and dissolved organic carbon. The median concentration of silica in Fremont Lake was about $1.4 \mathrm{mg} / \mathrm{L}$, a relatively low value (Peterson, Averett, and Mora, 1987) but closely agrees with the value of $1.2 \mathrm{mg} / \mathrm{L}$ reported by Rickert and Leopold (1972). Silica varies little with season. The small concentration of silica may be limiting diatom growth in Fremont Lake. Reid and Wood (1976, p. 244) report that silica concentrations of 0.5 to $0.8 \mathrm{mg} / \mathrm{L}$ limit, at least partially, the growth of some diatoms such as Tabellaria. Phosphorus and nitrogen were less than analytical detection limits [total phosphate 0.01 and $0.002 \mathrm{mg} / \mathrm{L}$ and total ammonia plus organic nitrogen, as nitrogen, less than $0.2 \mathrm{mg} / \mathrm{L}$ (Peterson, Averett, and Mora, 1987)]. Similar values were reported by Rickert and Leopold (1972). The mean dissolved organic carbon concentration was about $1 \mathrm{mg} / \mathrm{L}$. The chemical concentrations given above would classify Fremont Lake as dilute and oligotrophic, and the lake would not be conducive to excessive algal production.

Average phytoplankton concentrations by phylum for sampling periods during 1983-84 and 1989 are shown in figures 4 and 5 . Because the lake depth at the water-supply inlet (site 3 ) is a maximum of about $24 \mathrm{~m}$, phytoplankton concentrations are computed from water samples collected between the water surface and lake bottom for site 3 and from water samples collected between the water surface and depths to $24 \mathrm{~m}$ for site 1 . Total phytoplankton concentrations are from data in tables 1 and 2; average concentrations normalize data by dividing the total cells-per-milliliter count by the number of water samples in the sample set. Samples collected at depths listed in table 2 as greater than the lake bottom at the water-supply inlet are from deeper water just adjacent to site 3 . Only during some of the 1984 sampling periods were there large numbers of phytoplankton (fig. 4). During 1984, diatoms and golden-brown algae were most abundant in the June samples, an expected occurrence because of the lower water temperatures and spring growth patterns. In August 1984, the green algae were most abundant, followed by the blue-green forms. Diatoms had decreased in abundance in August. There was a strong thermal gradient in the surface waters at this time, which decreased mixing and caused the diatoms to sink. Green and blue-green algae again were dominant in October 1984. Similar patterns occurred in 1989 , with the exception that golden-brown algae remained dominant for all sampling periods except for August; but the concentrations of phtyplankton were much less for each phylum (fig. 5). Noteworthy during 1989 is that the concentrations of blue-green algae remained somewhat constant, never reaching high concentrations at any time. Dinoflagellates were absent in all of the 1989 samples and occurred only in three of the six samples during 1983-84. Even the highest average concentration of about 8,000 cells $/ \mathrm{mL}$ for blue-green algae is low compared to findings during bloom conditions in eutrophic lakes. Secchi-disk depths for the 1983-84 samples also are shown in figure 4 . They were not recorded in 1989. These are relatively large depths, indicating the clarity of Fremont Lake water as described by Peterson, Averett, and Mora (1987). Shallow Secchi-disk depth in water commonly can indicate profuse algal production.

A total of 146 species of phytoplankton were identified in the samples collected during 1983-84 and in 1989 (tables 1 and 2). Although the relative abundance of some species over others was apparent, no species was consistently dominant. The depth distribution of phytoplankton from the 1983-84 samples has been described by Peterson, Averett, and Mora (1987). The depth patterns are those typical of clear lakes, and the greatest cell concentrations occur at greater depths during the warmest periods of the year. The diatom Rhizosolenia eriensis was abundant at great depth, (1,032 cells $/ \mathrm{mL}$ at the $120-\mathrm{m}$ depth in June 1984). Rhizosolenia obviously is one of the most abundant diatoms in Fremont Lake, as a similar pattern of abundance was observed in 1989 (table 2). The golden-brown algae Dinobryon also was collected at depth in the 1983-84 and 1989 samples. The most common golden-brown algae during 1989 was Ochromonas minuta. The species was not identified during 1983-84.

The most abundant green algae at depth during 198384 and 1989 were Chlamydomonas and Chlorella. These two genera were most common in the June 1984 samples, but their concentrations were never high. Volvox was the most abundant genus in the 1984 samples, approaching 20,000 cells $/ \mathrm{mL}$ in the August sample at the $15-\mathrm{m}$ depth.

Most attention in lake algal studies is directed towards blue-green algae. Some species within the phylum can utilize atmospheric nitrogen as a nutrient source. In Fremont Lake the blue-green algae Aphanocapsa delicatissima, a small species having cells distributed within a mucilage sheath, was the most abundant during August and October 1984 and was common in many of the 1989 samples. How- 


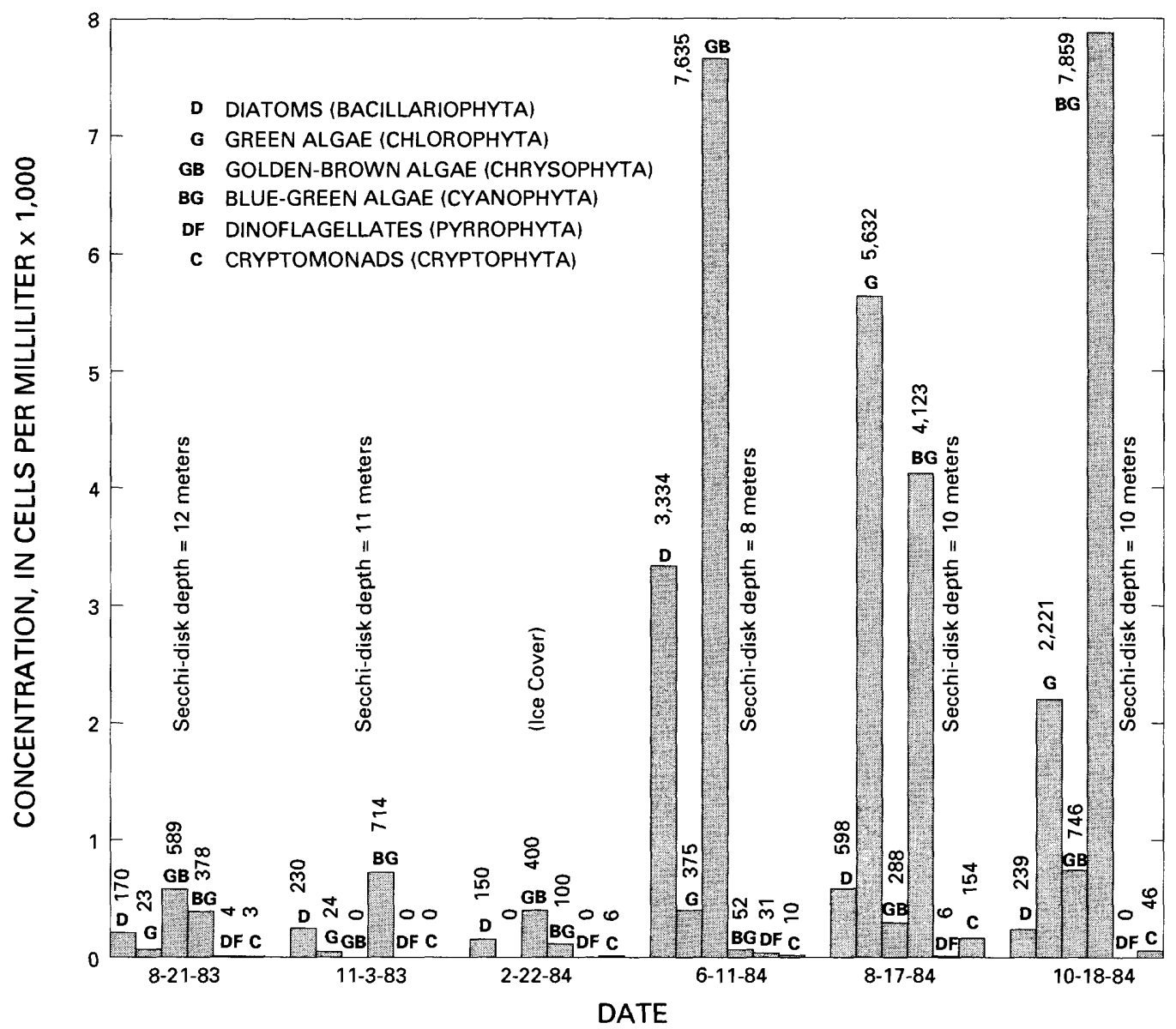

Figure 4. Average phytoplankton concentrations from water surface to 24-m depth and Secchi-disk depths (site 1), 1983-84 sampling dates. 


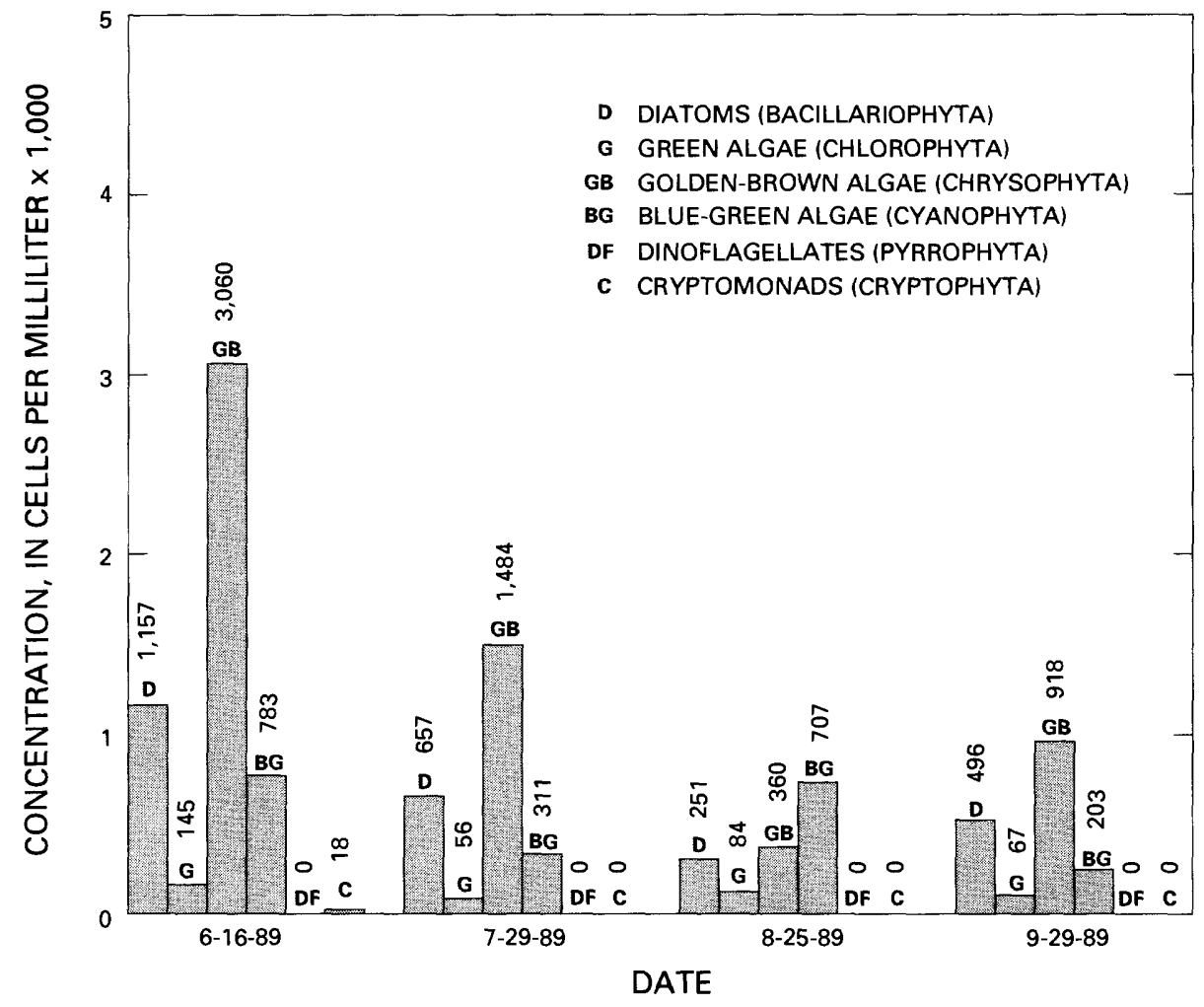

Figure 5. Average phytoplankton concentrations from water surface to lake bottom (less than or equal to 24-m depth) at site 3, 1989 sampling dates. No Secchi-disk depths were determined. 


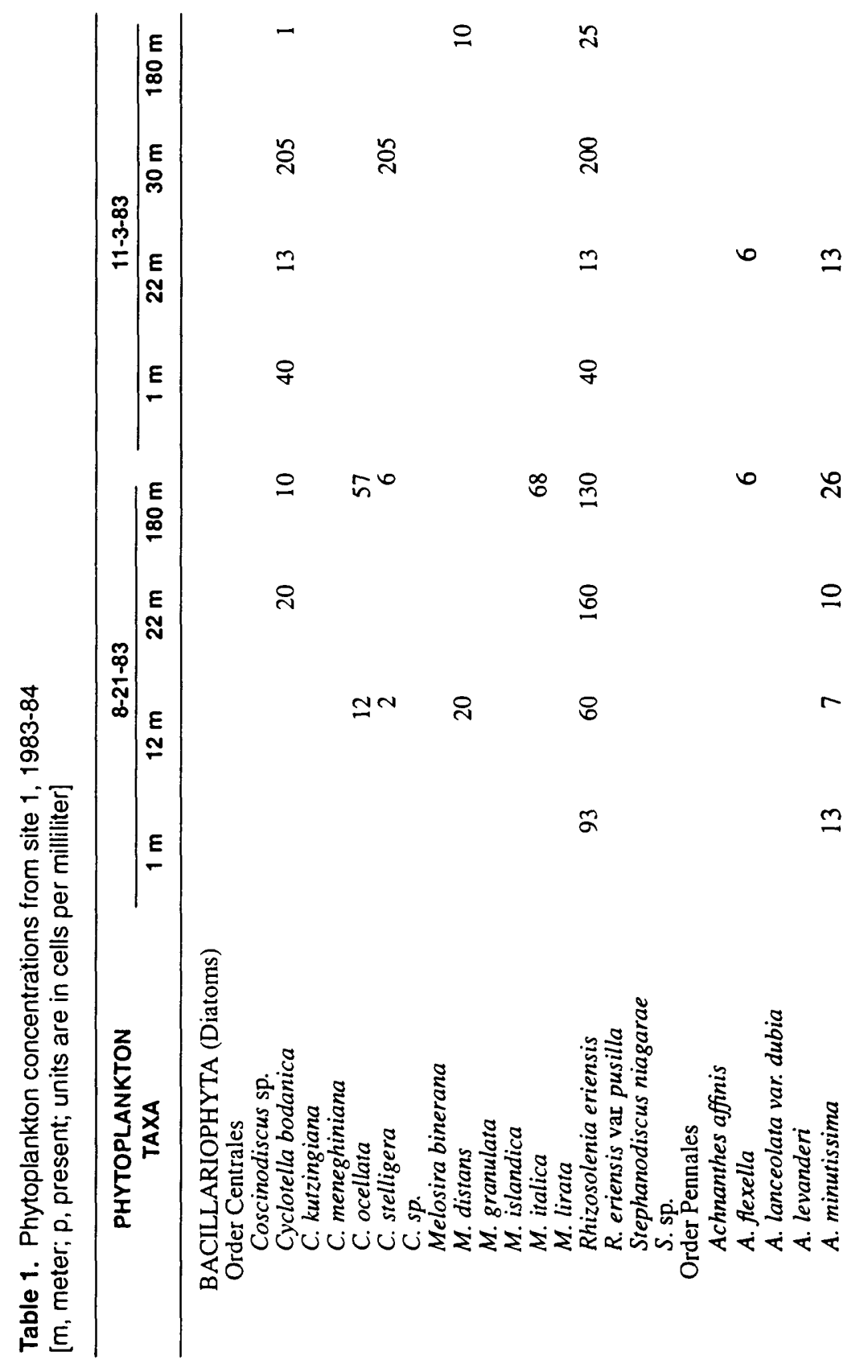




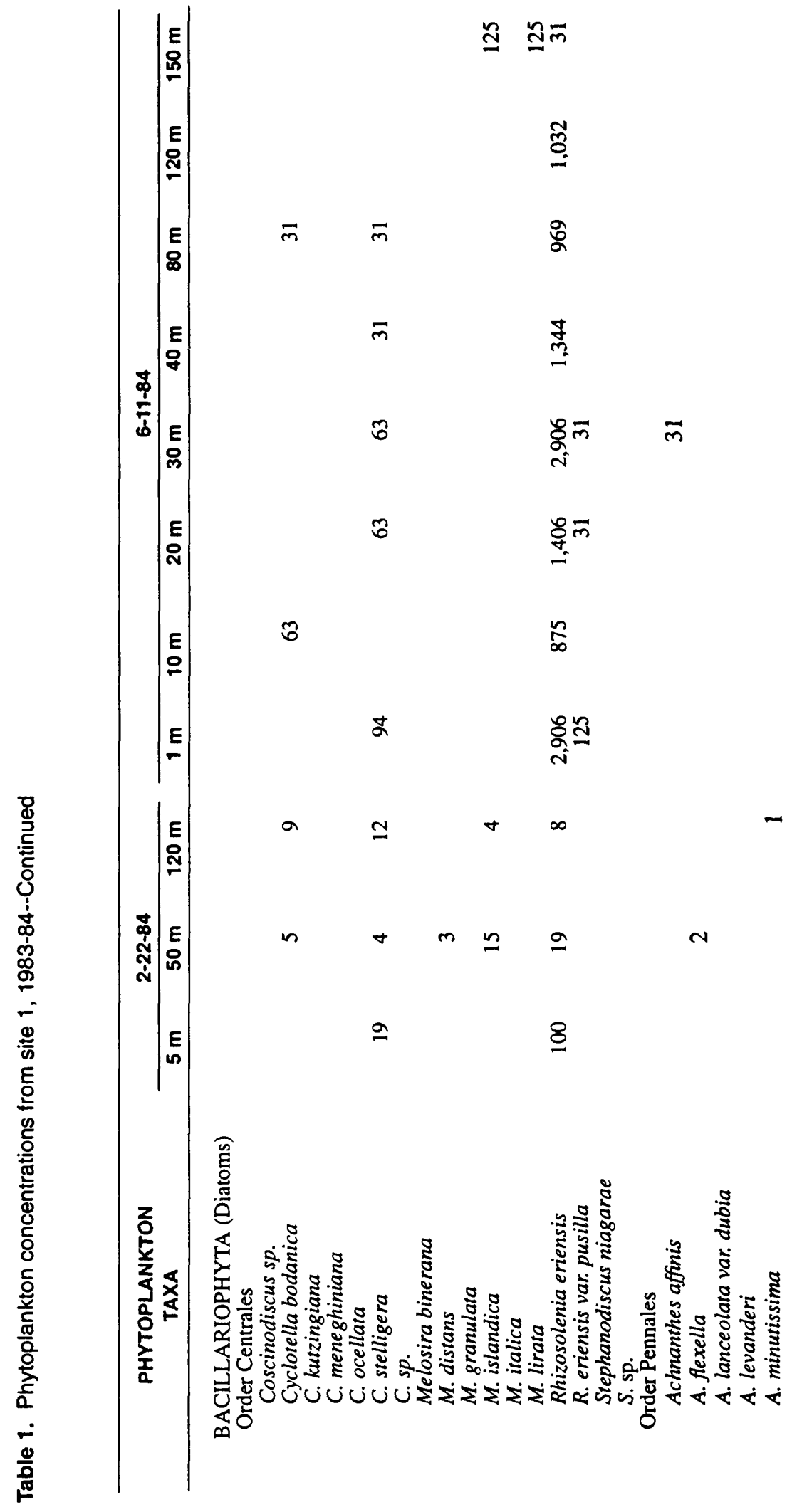




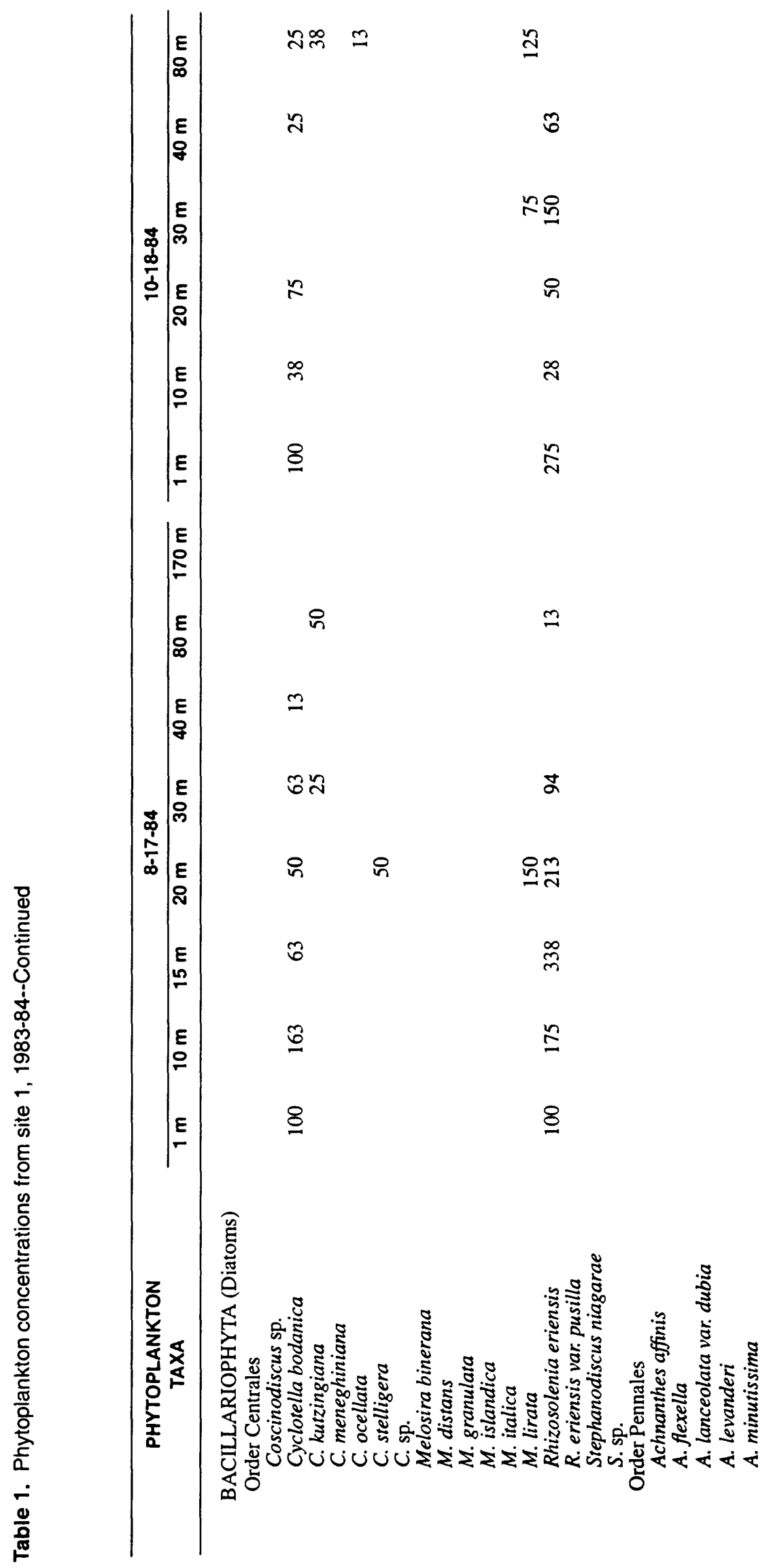




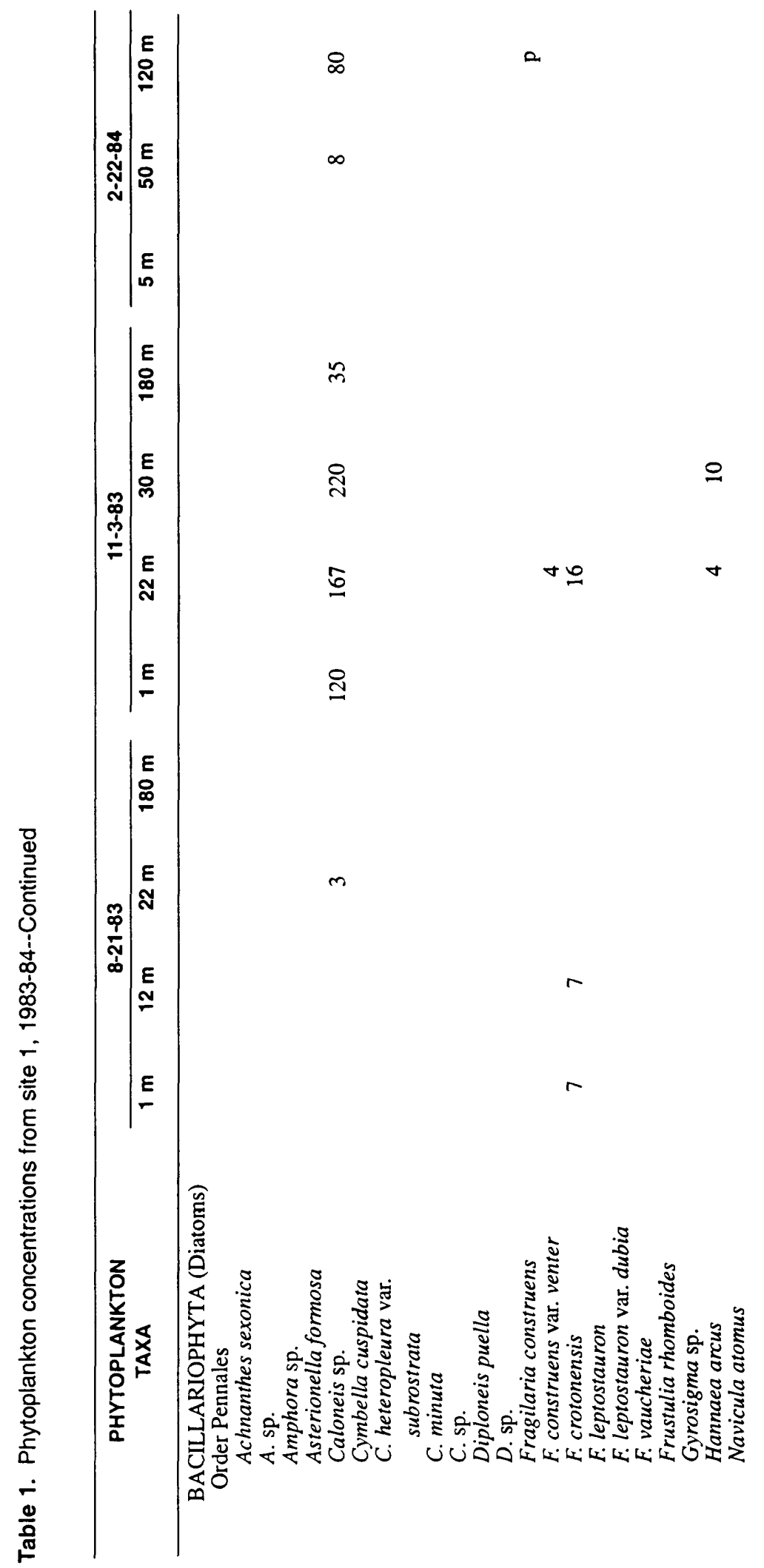




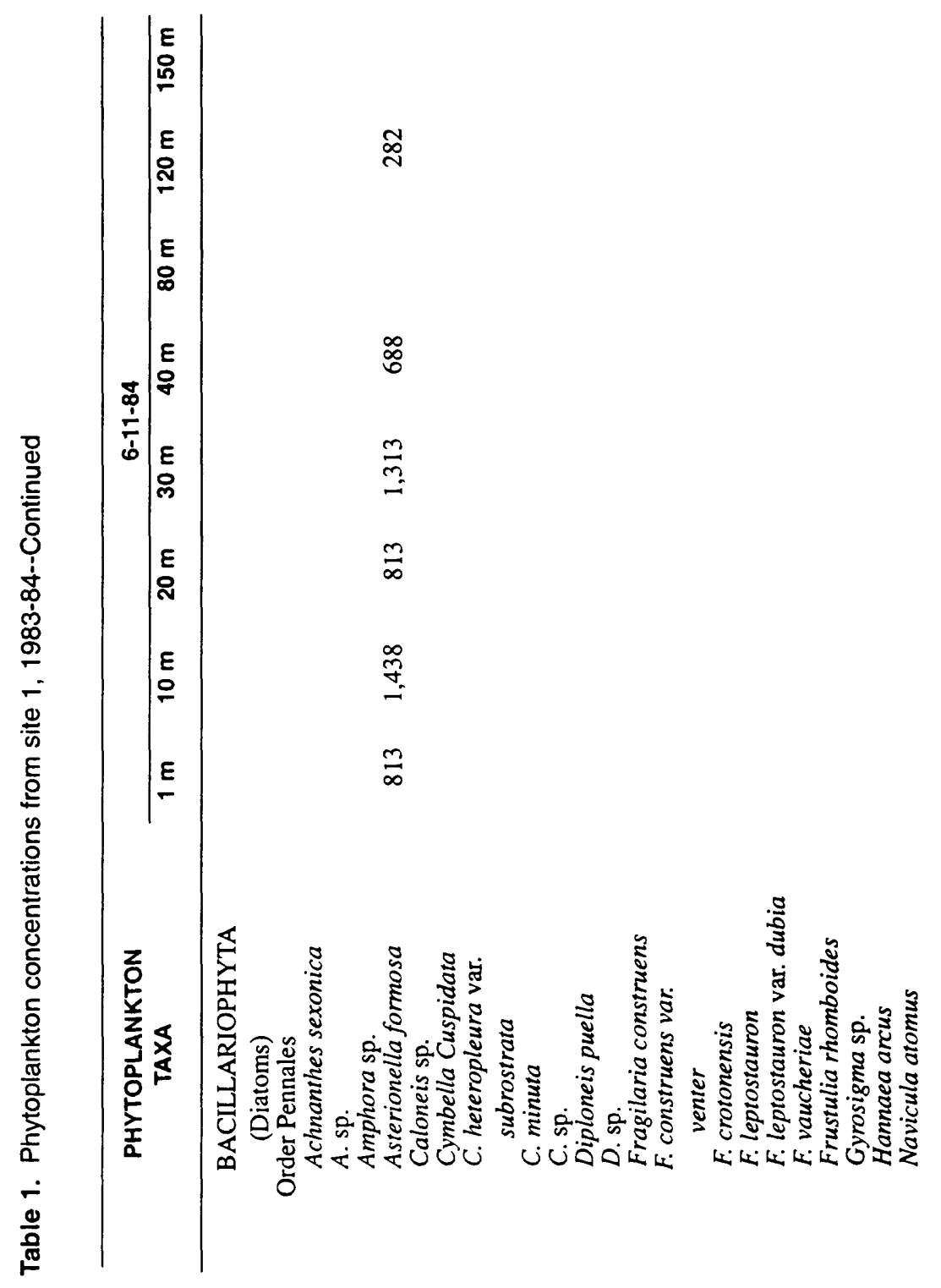




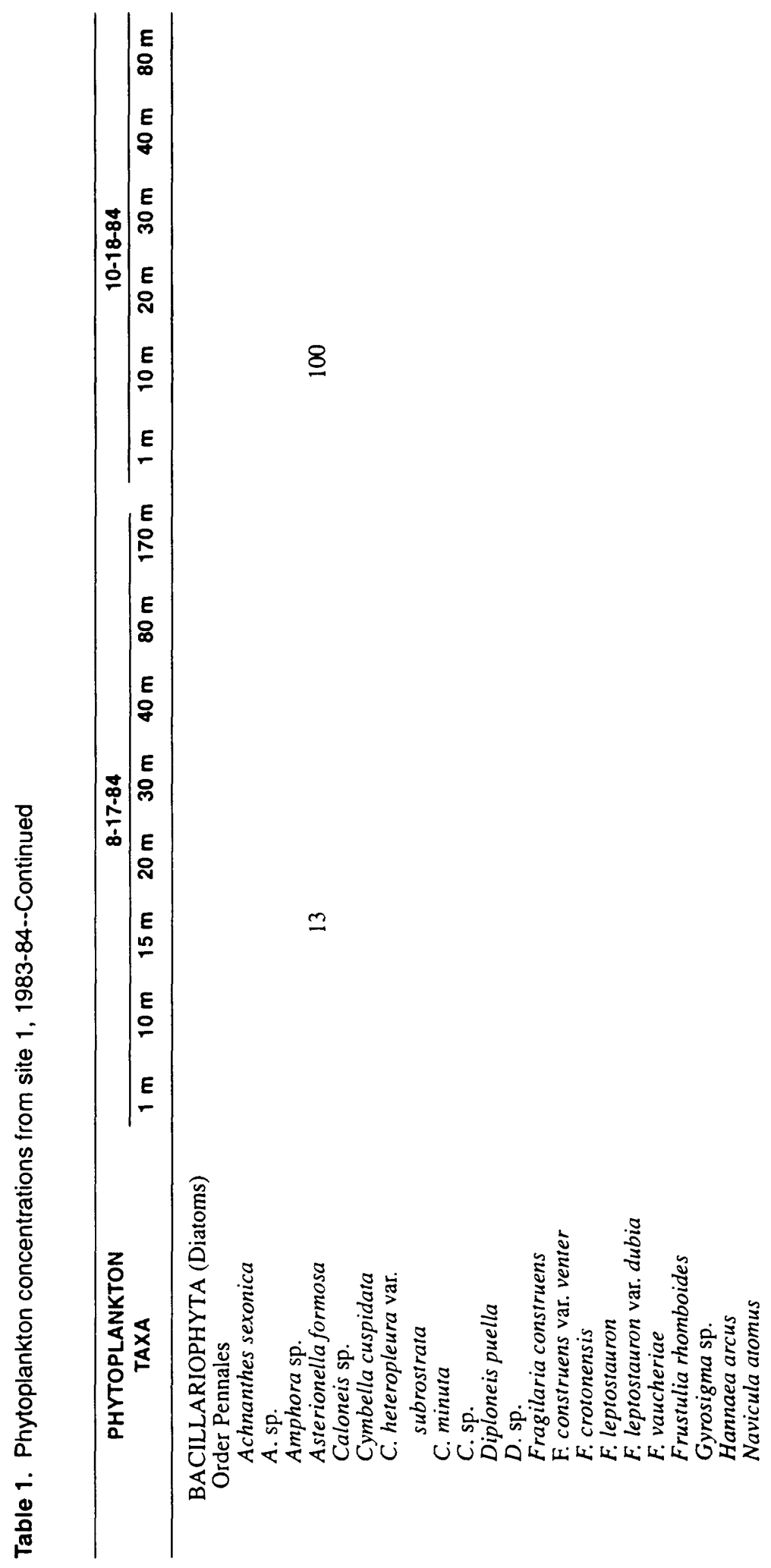




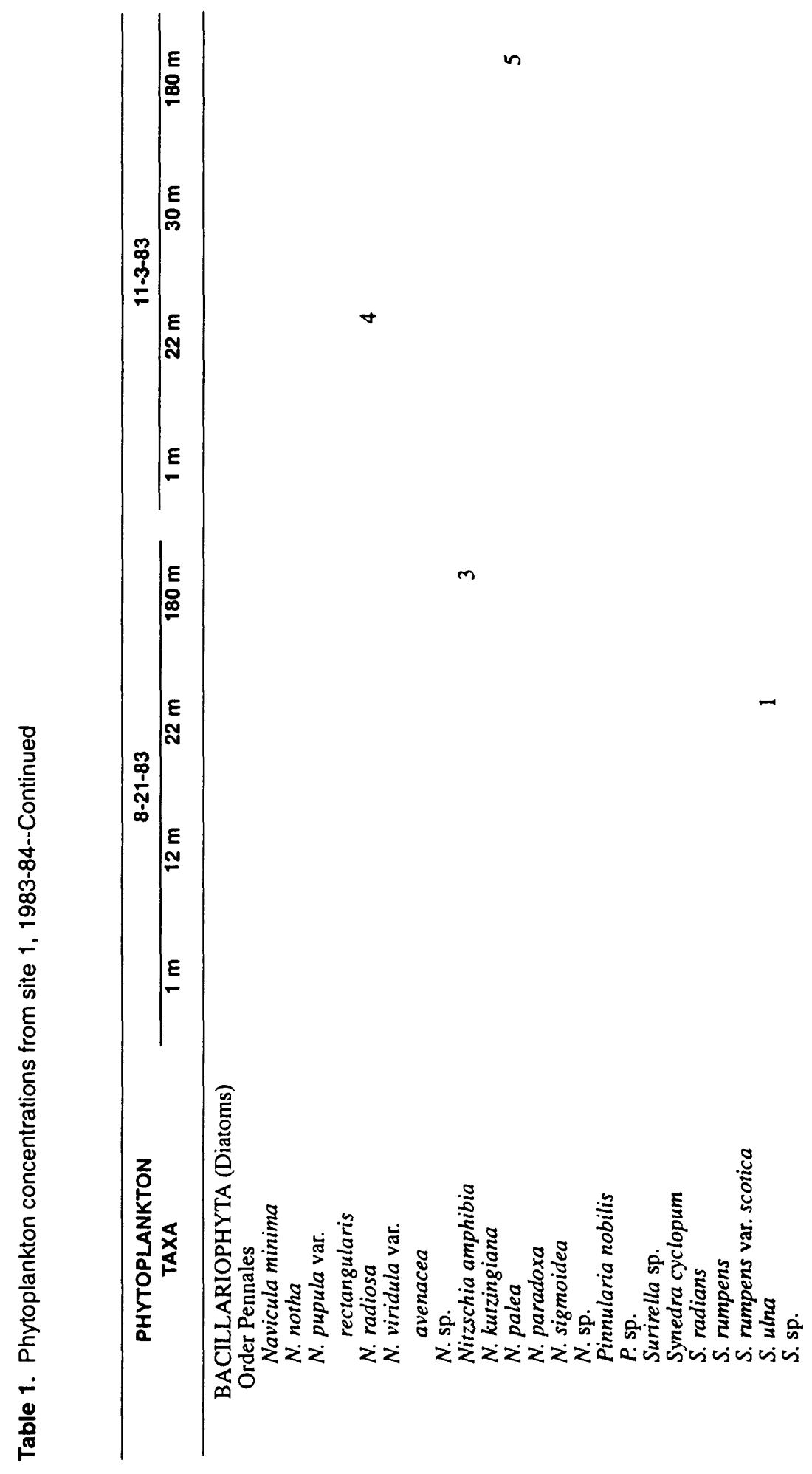




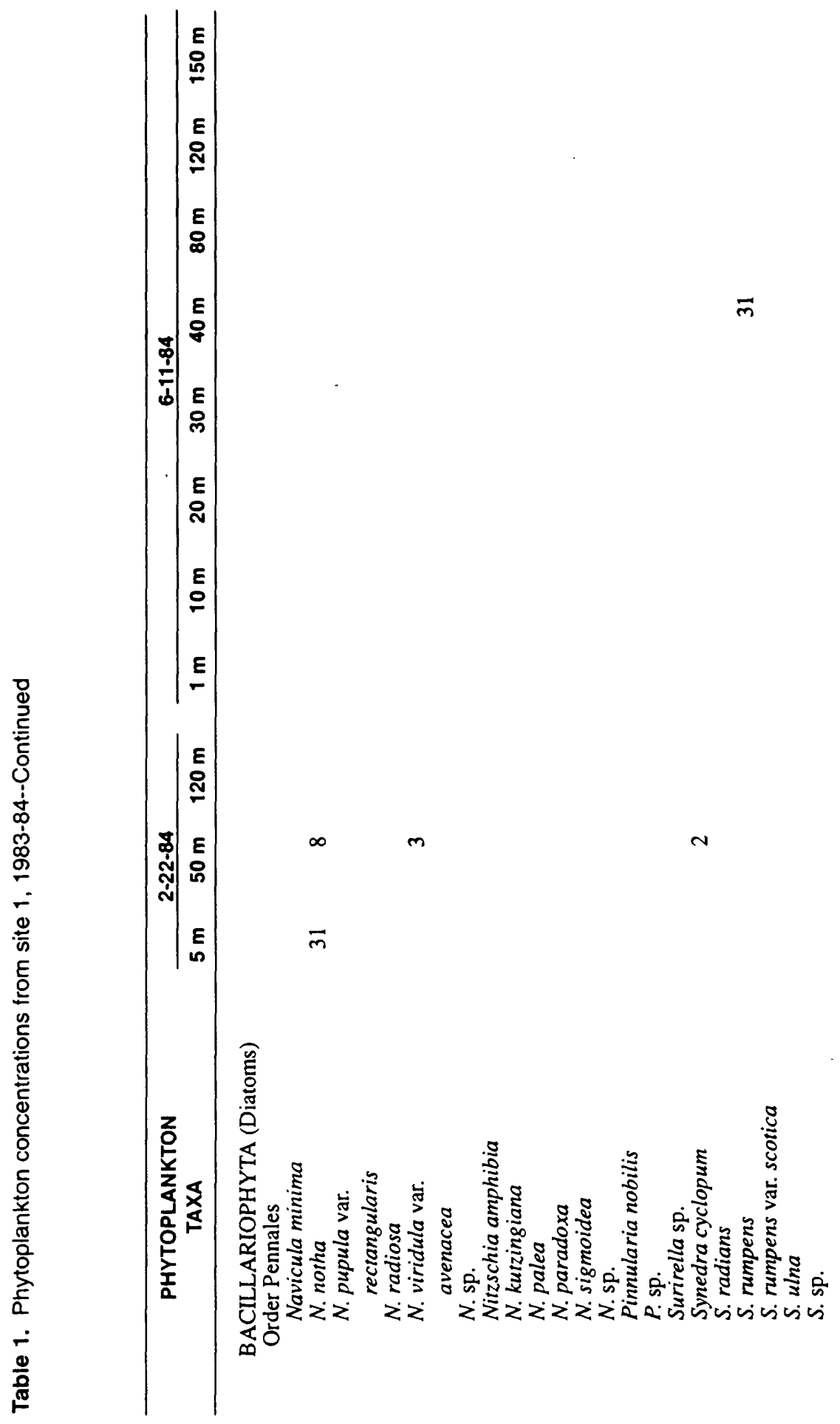




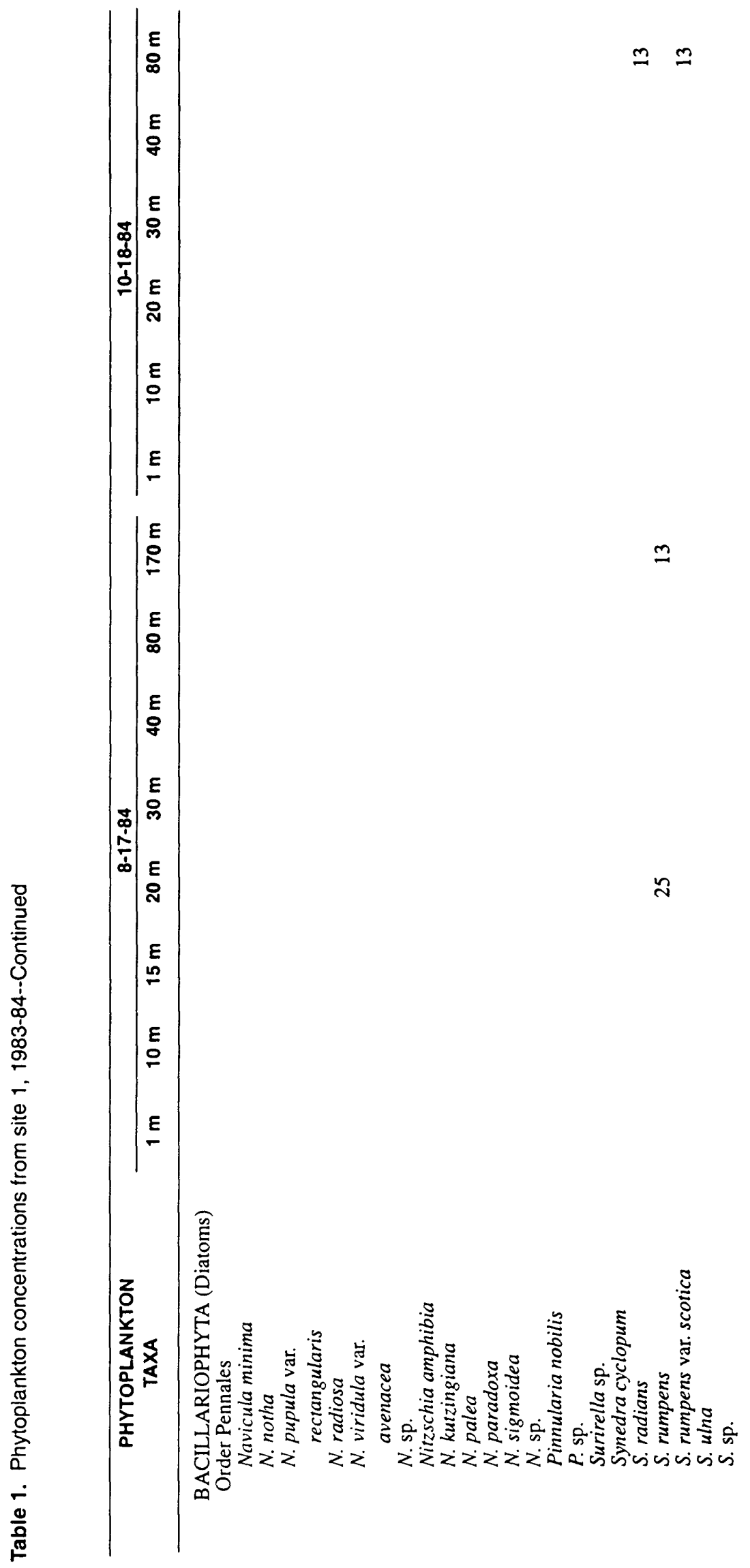




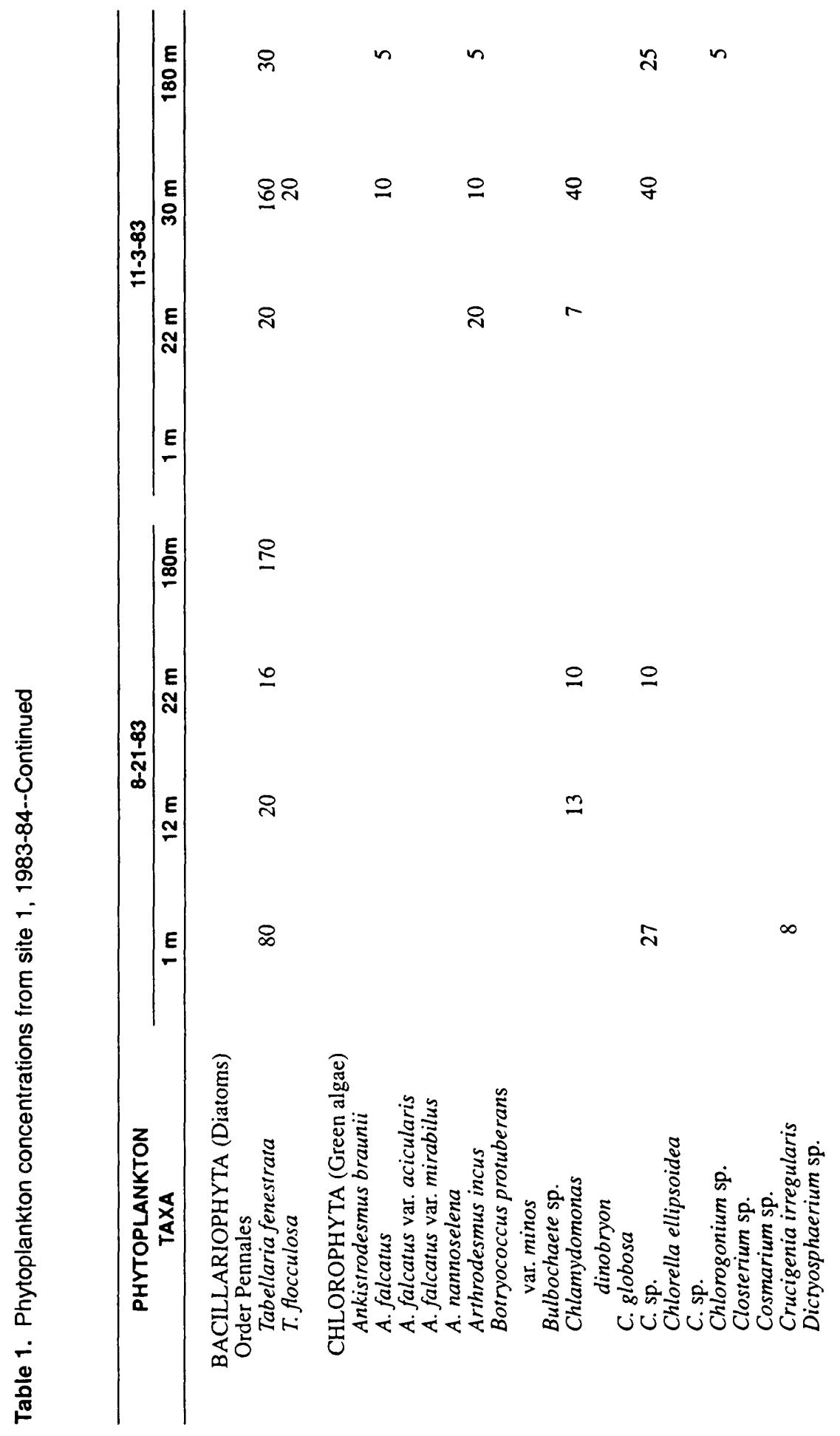




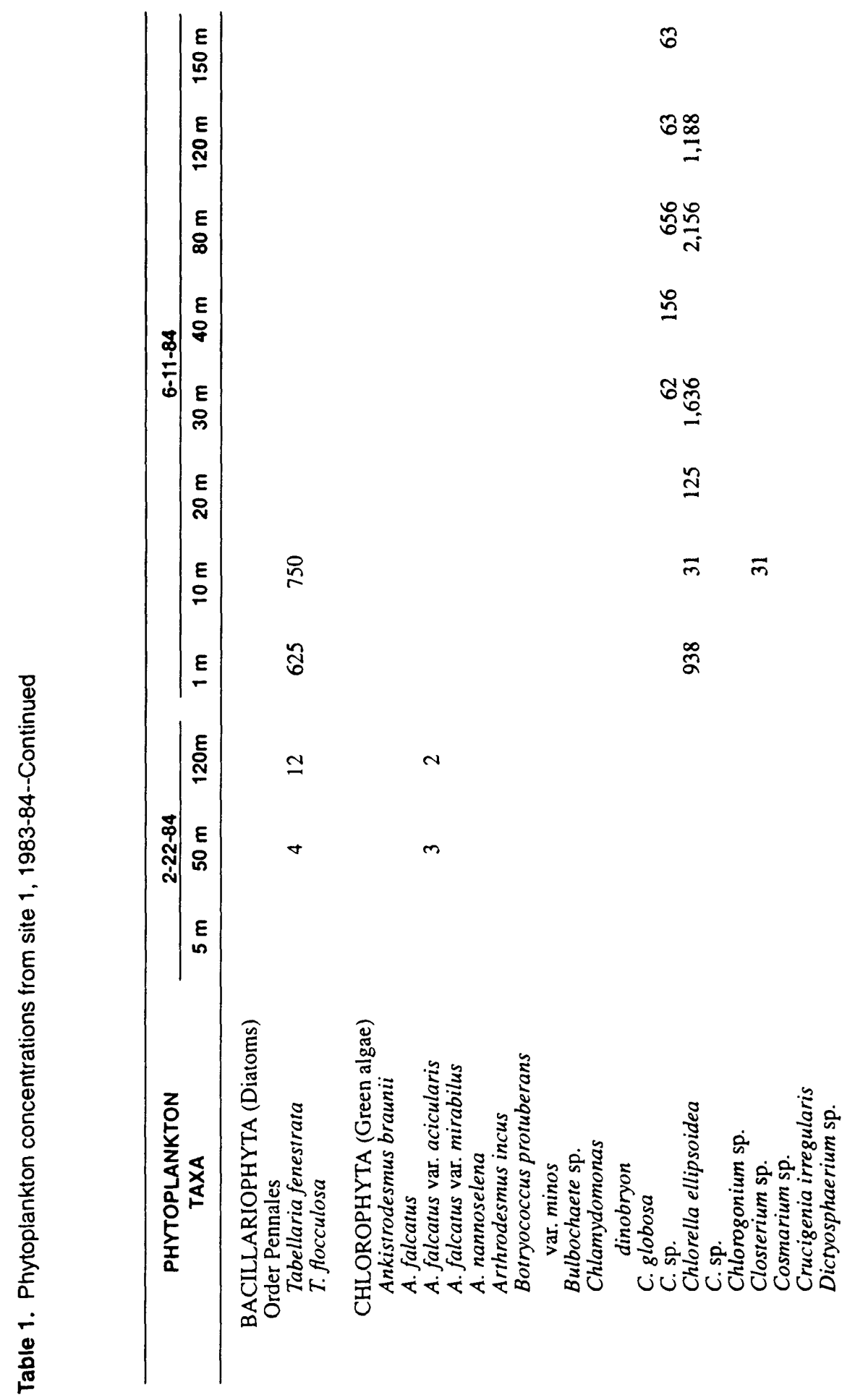




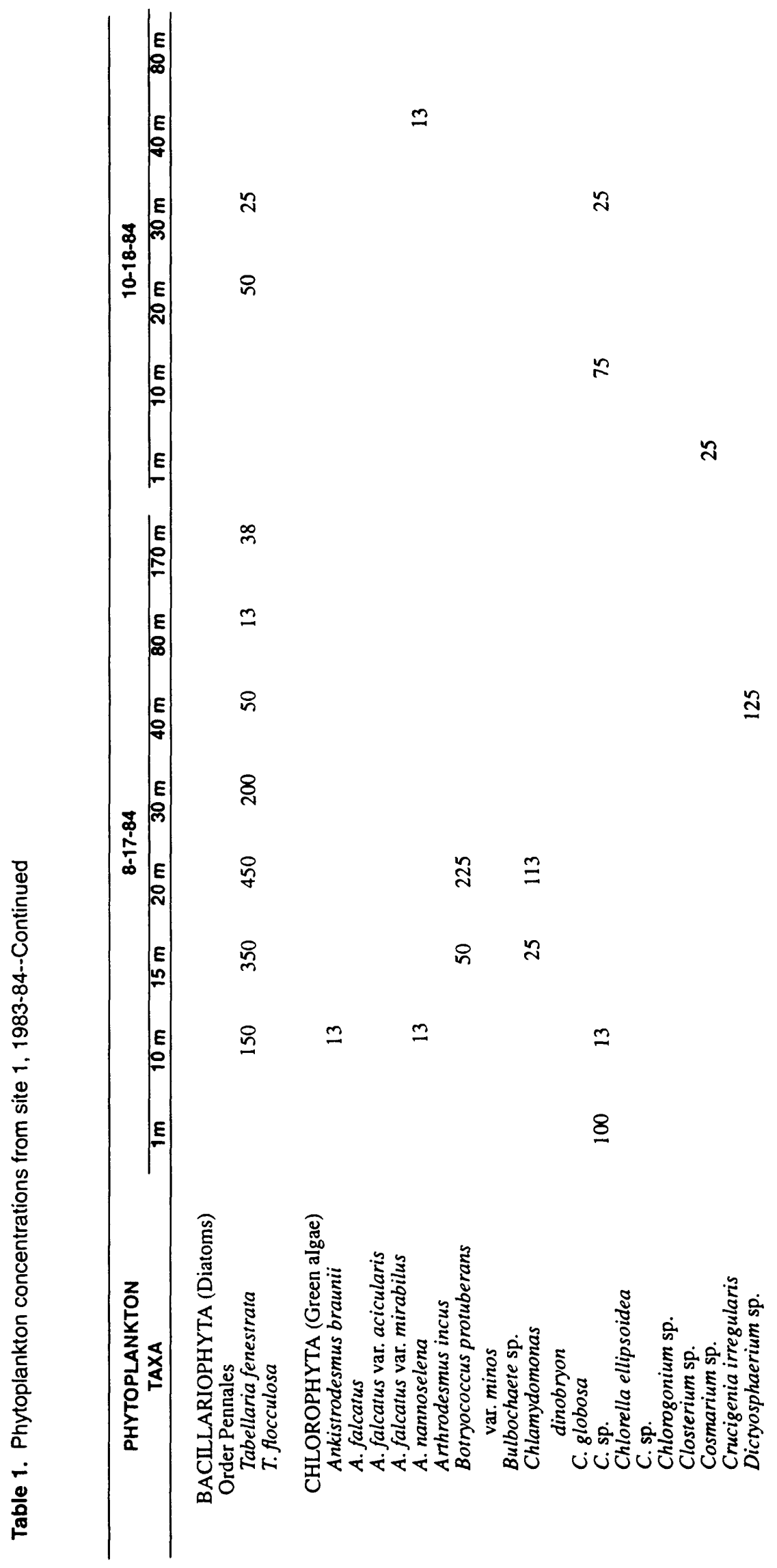




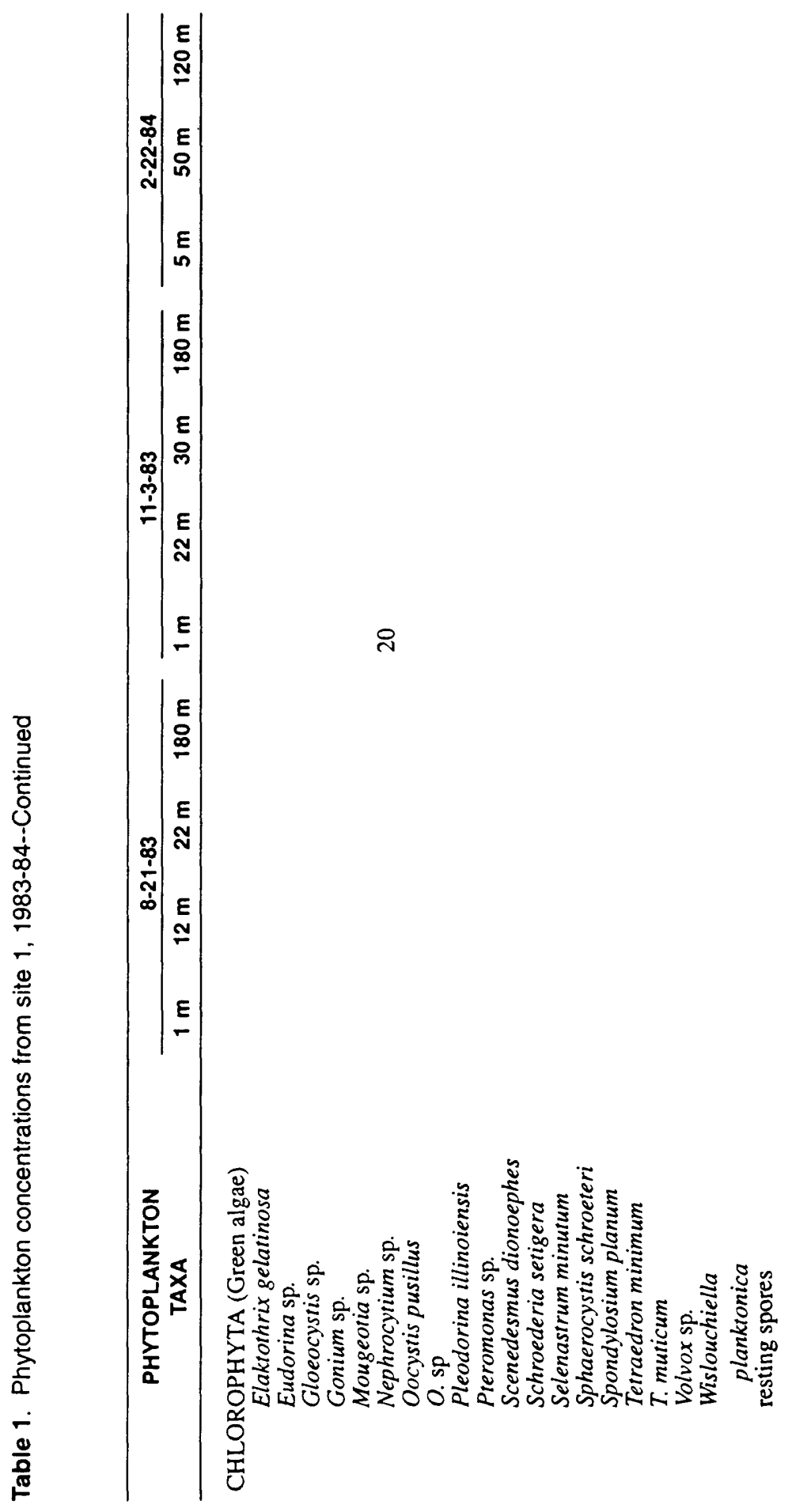




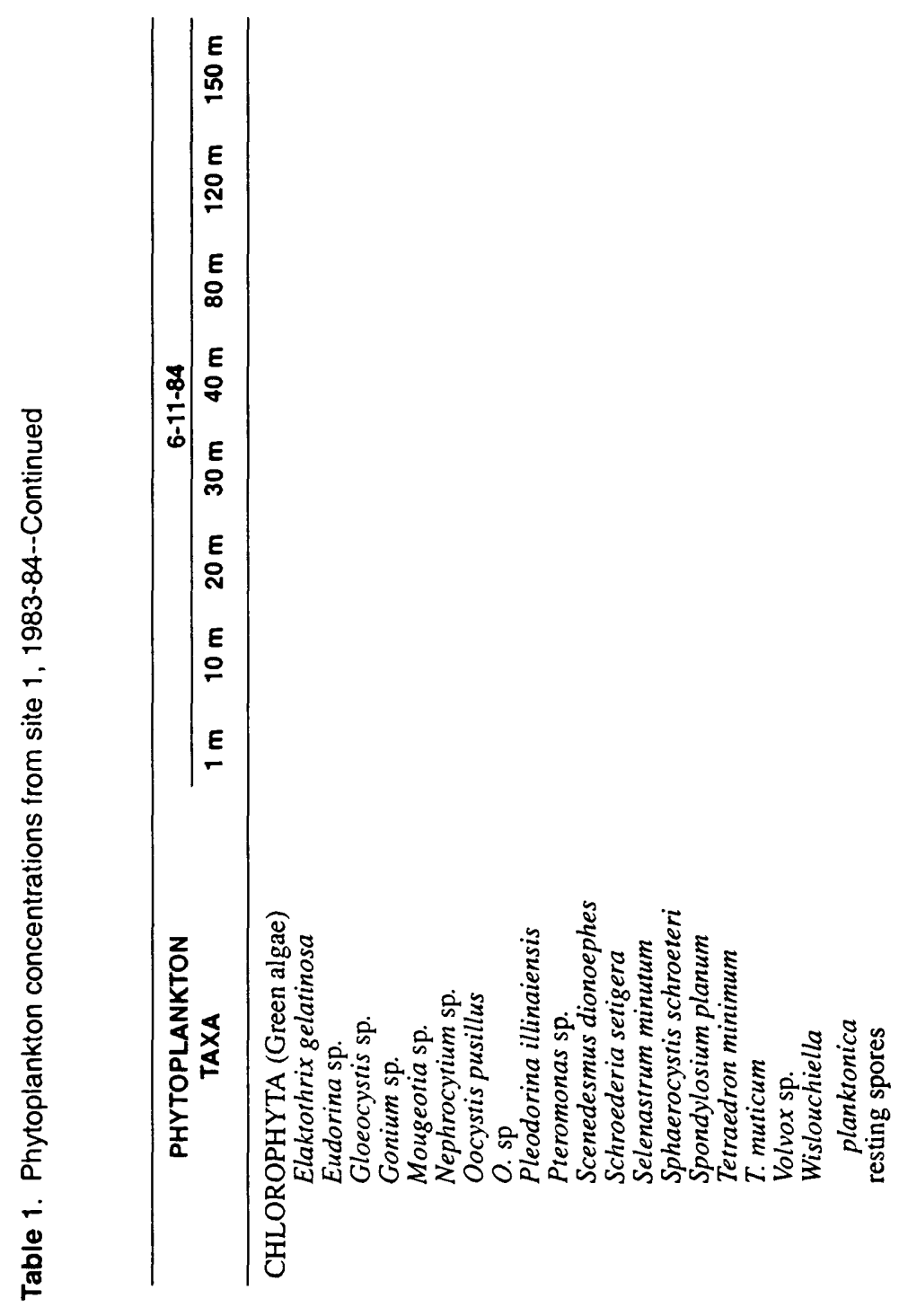




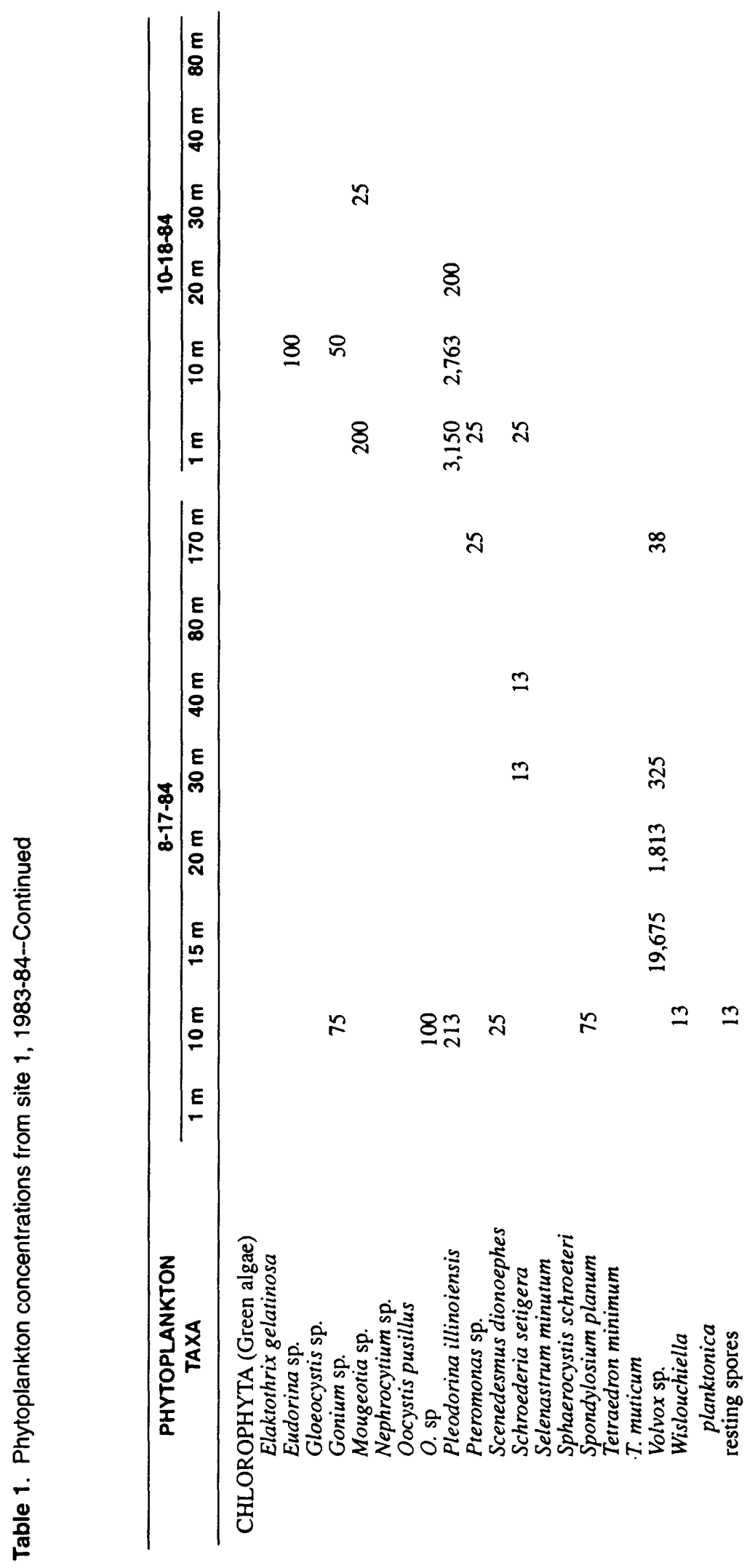




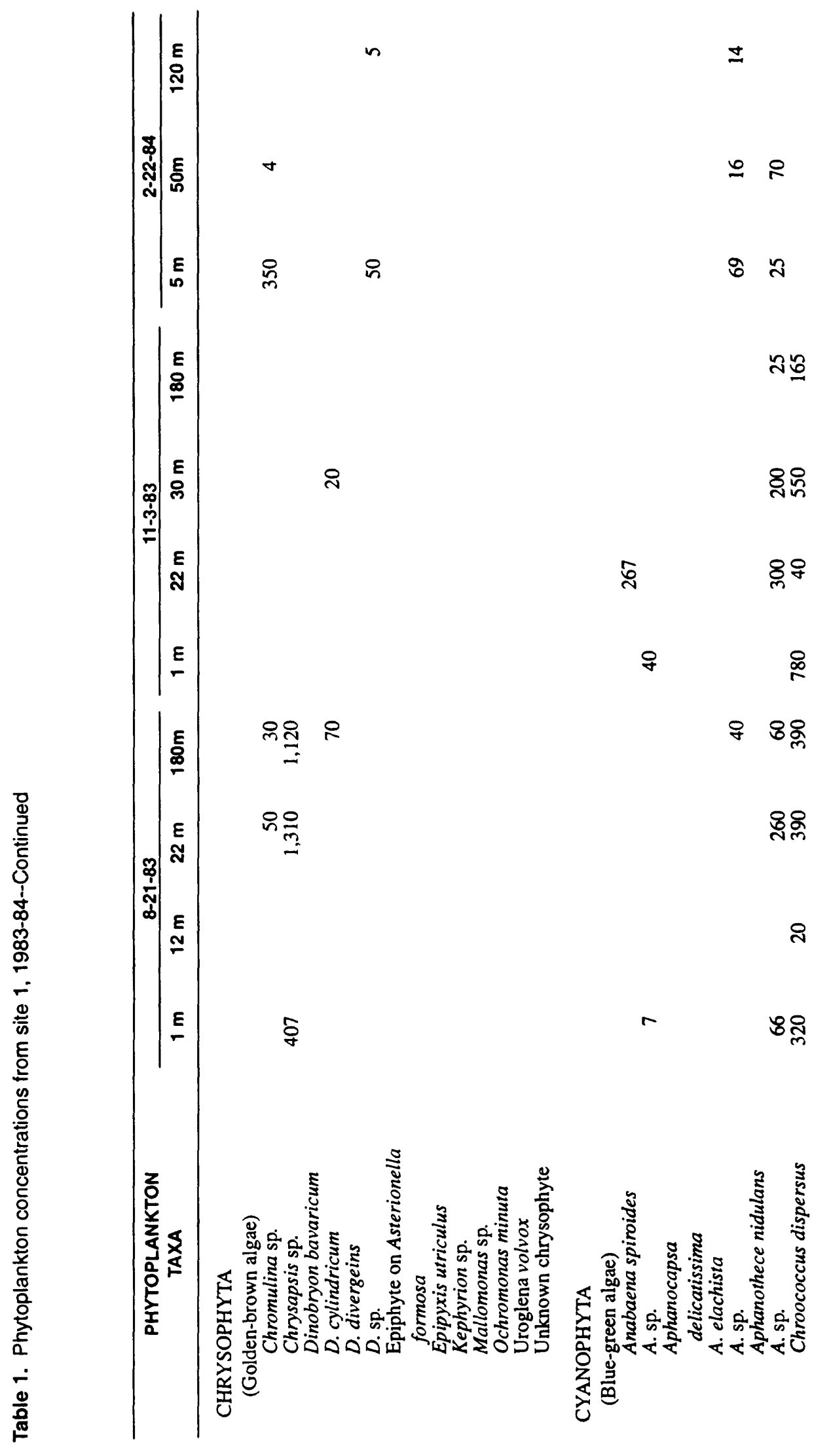




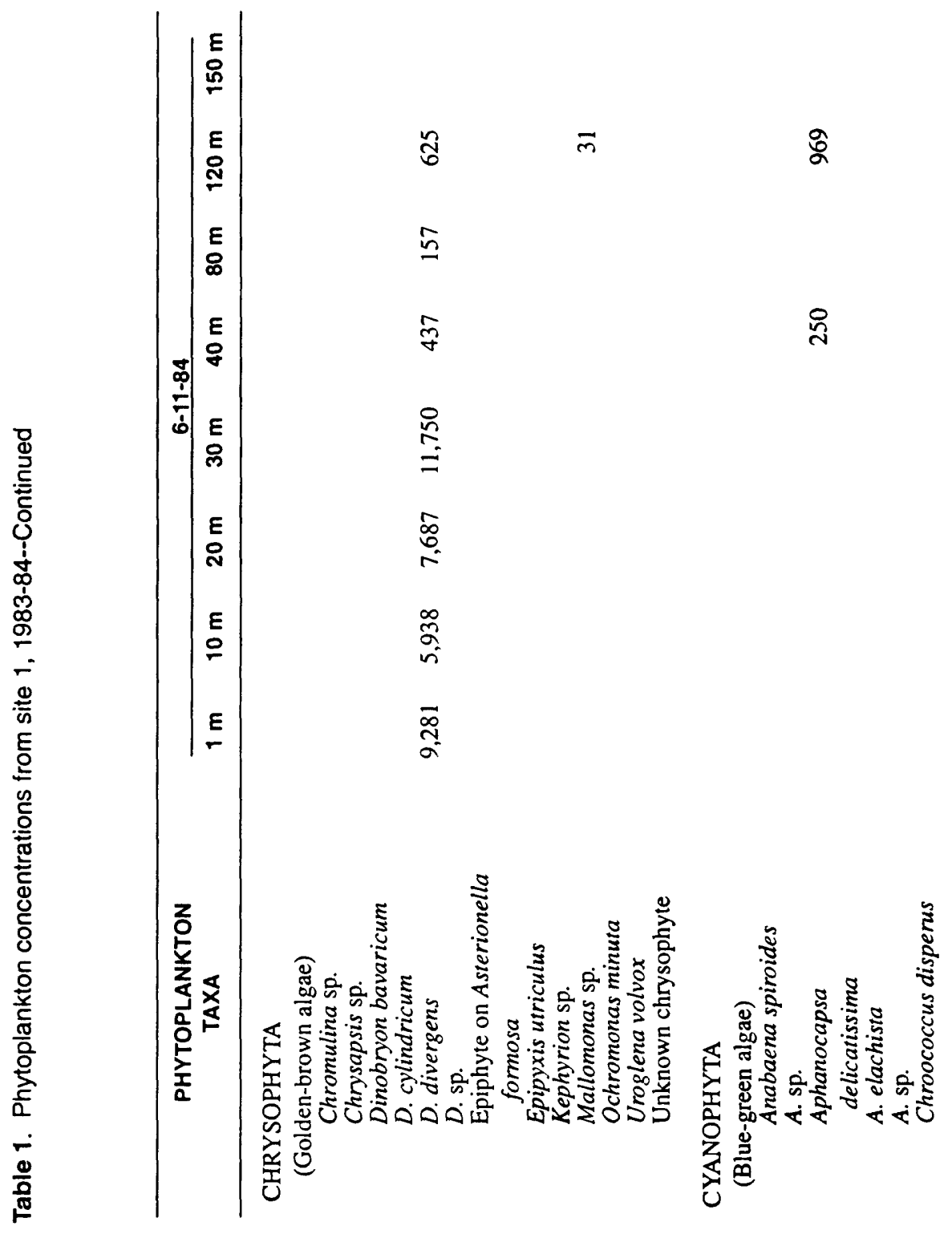




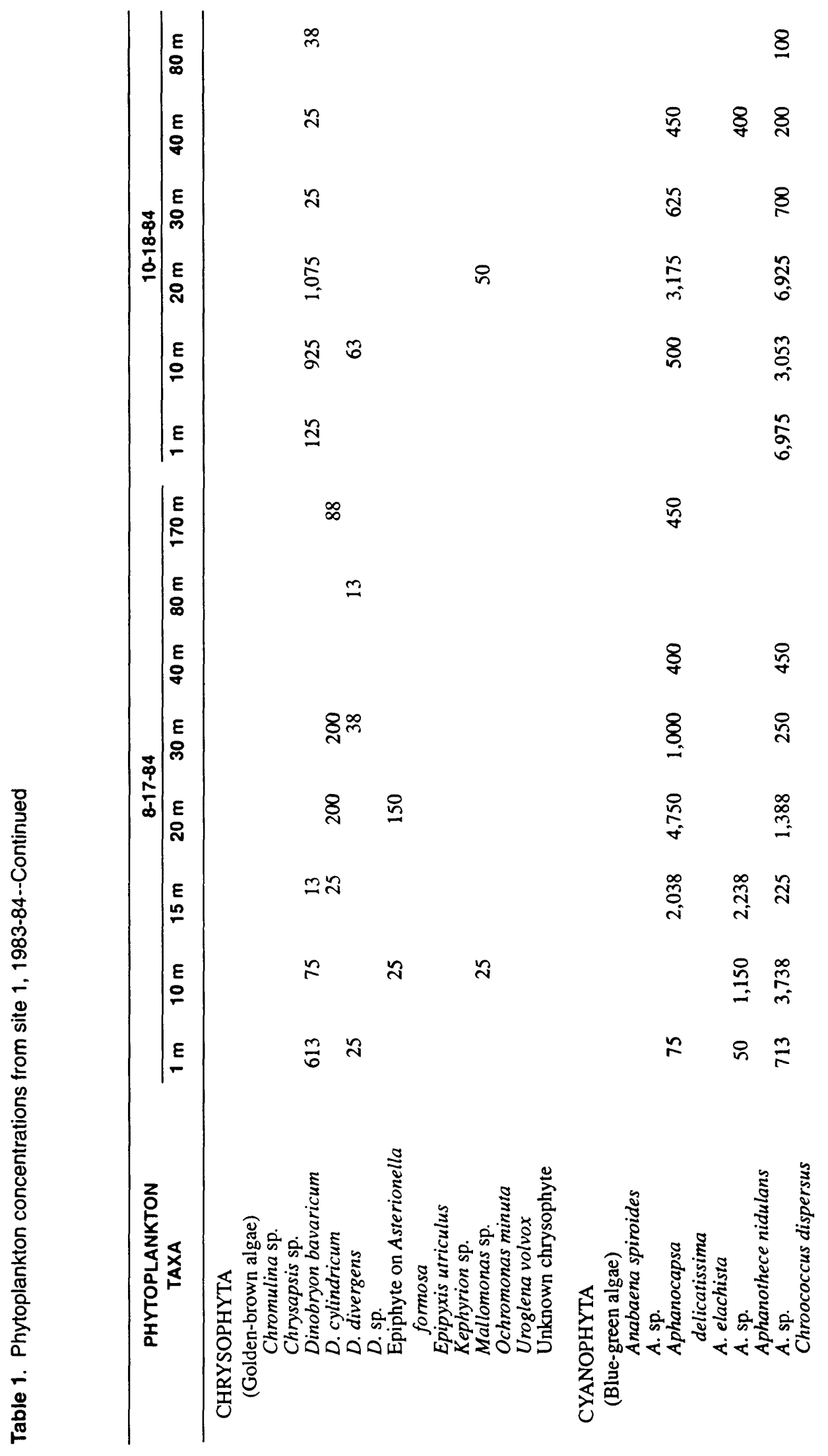




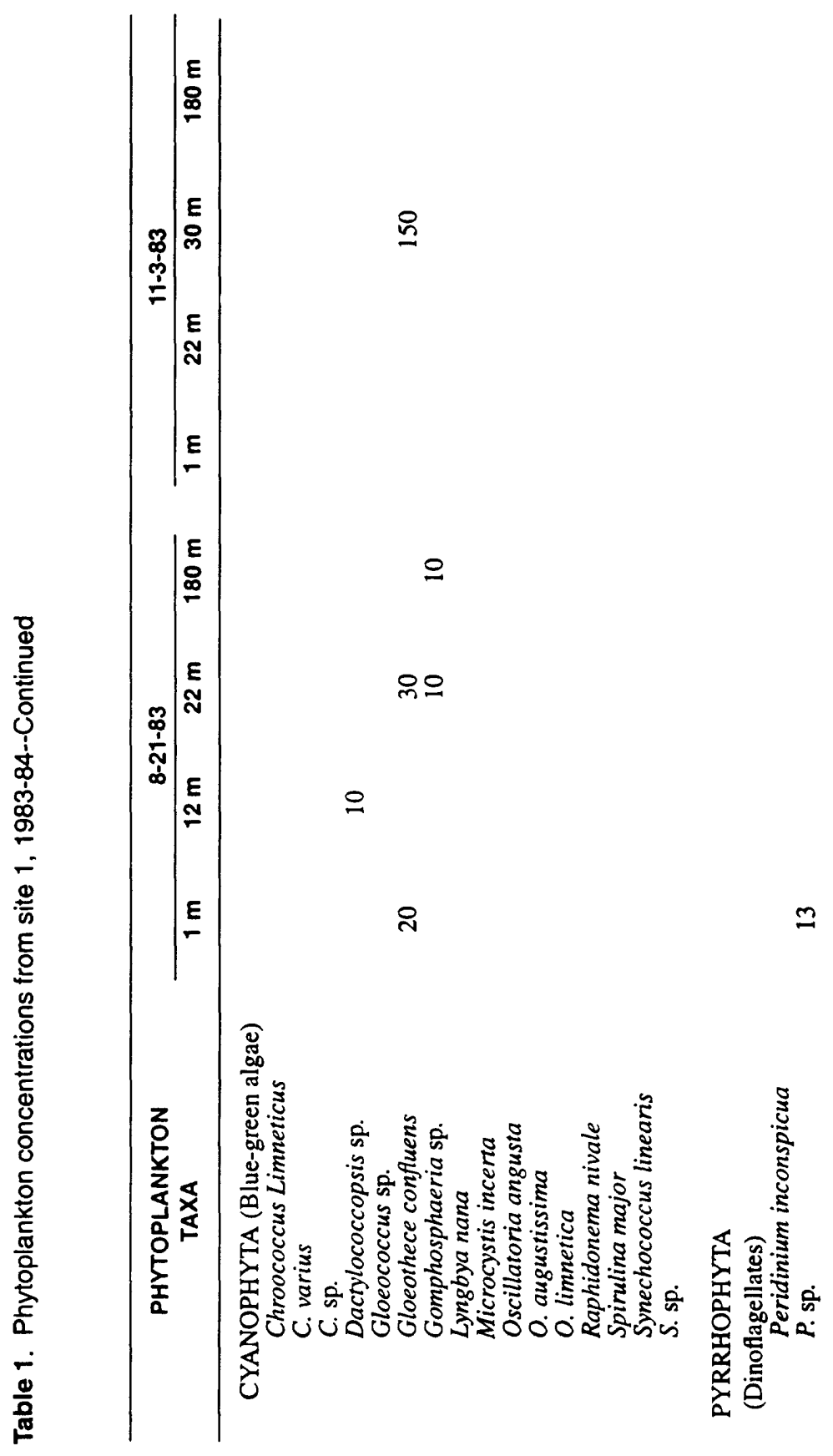




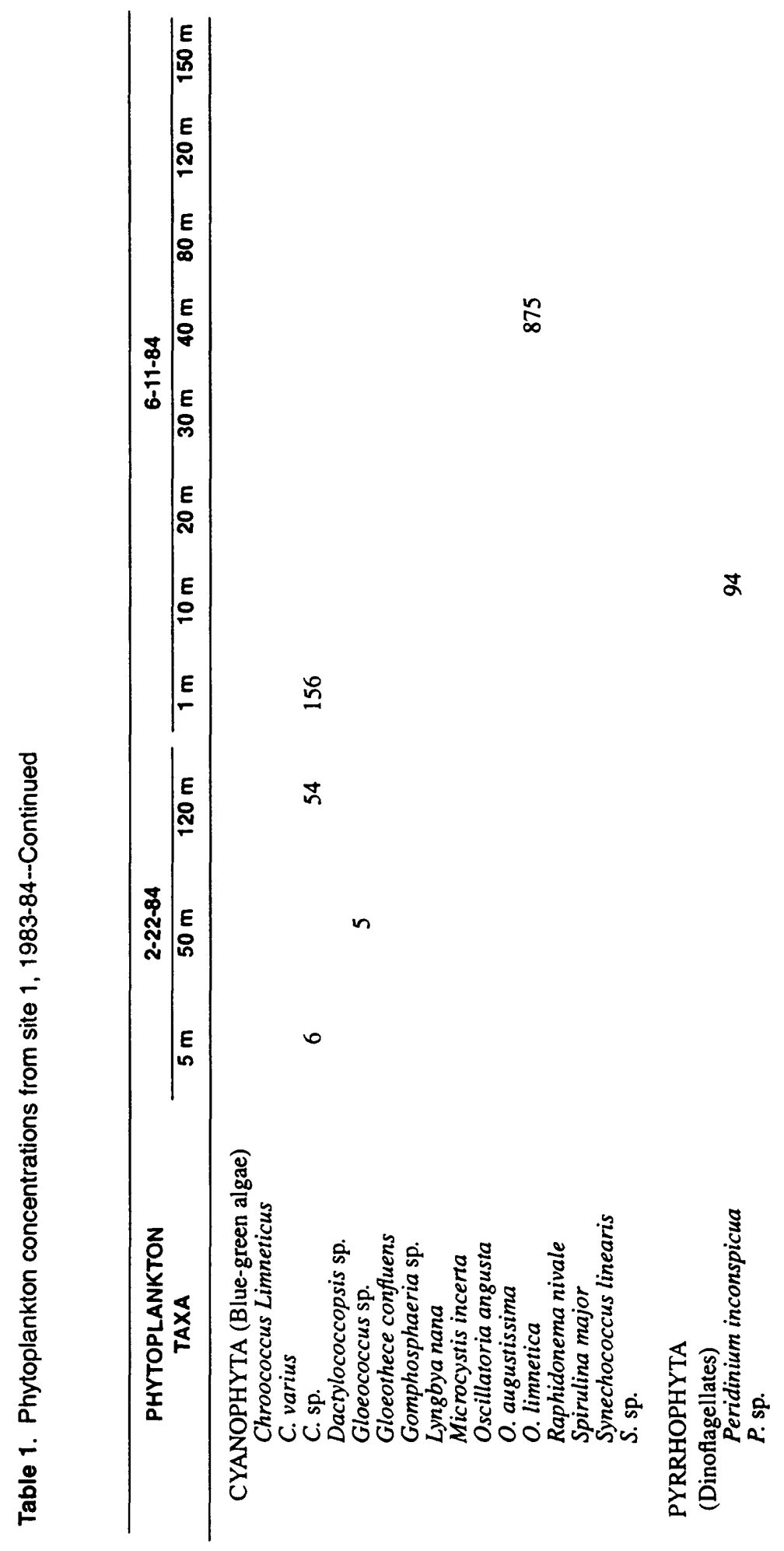




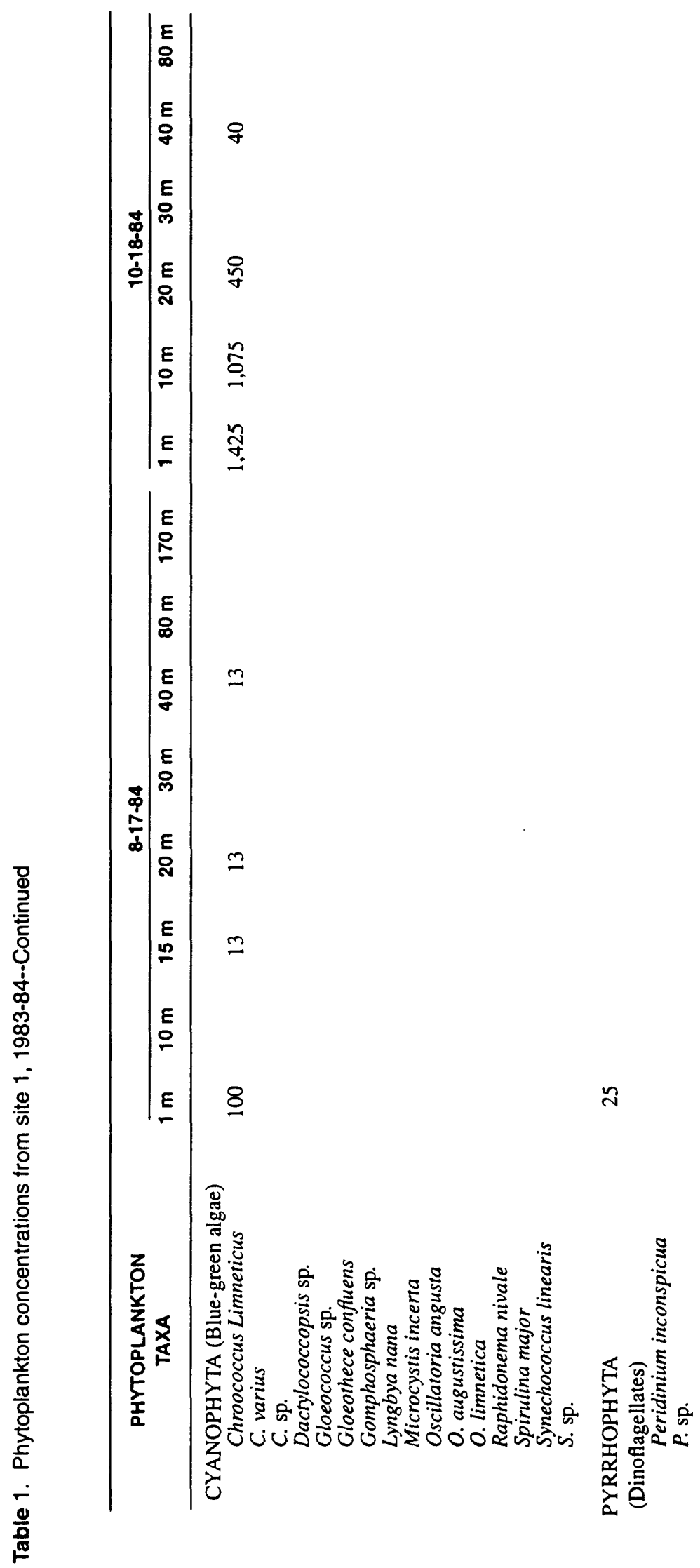



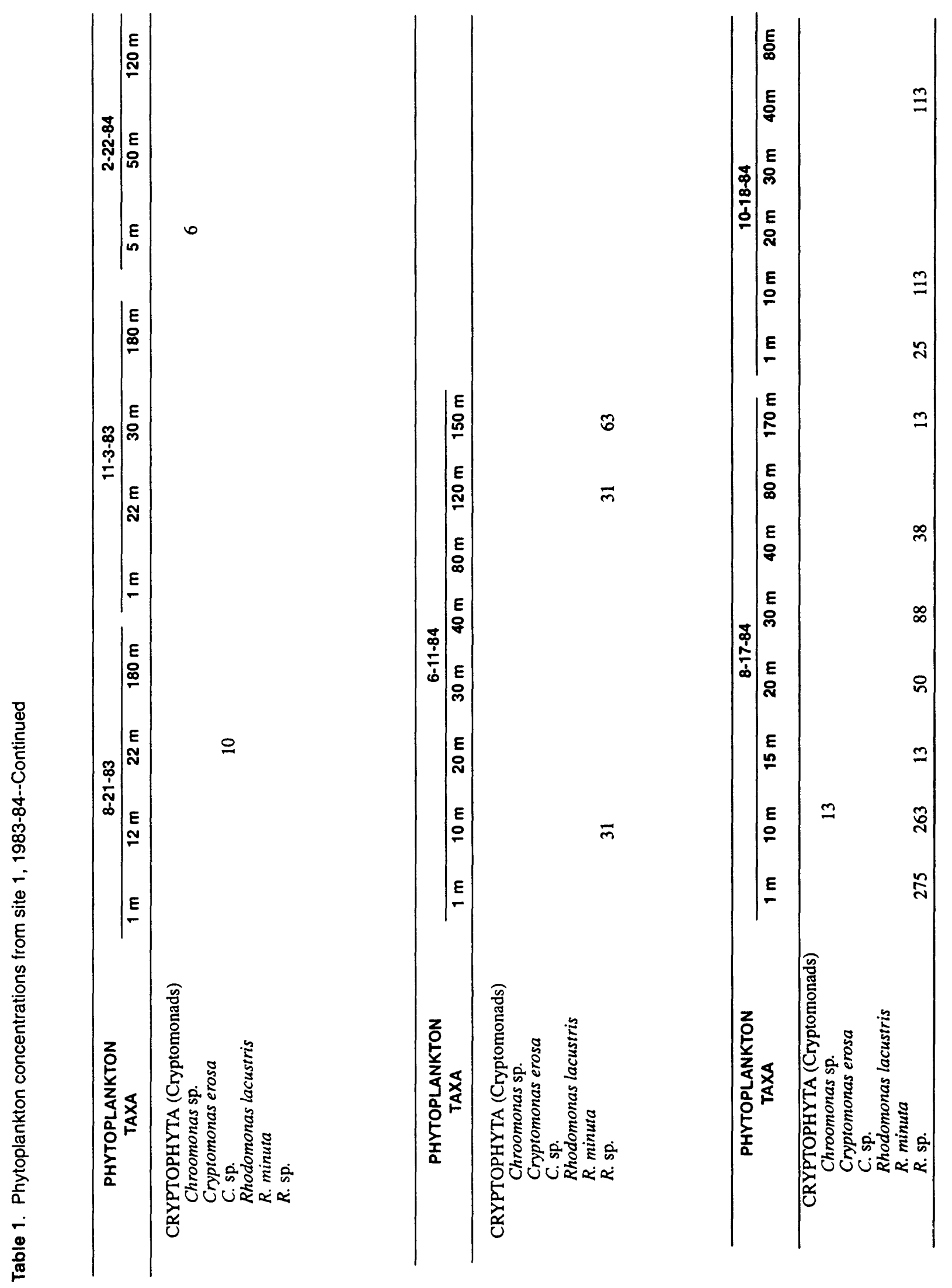


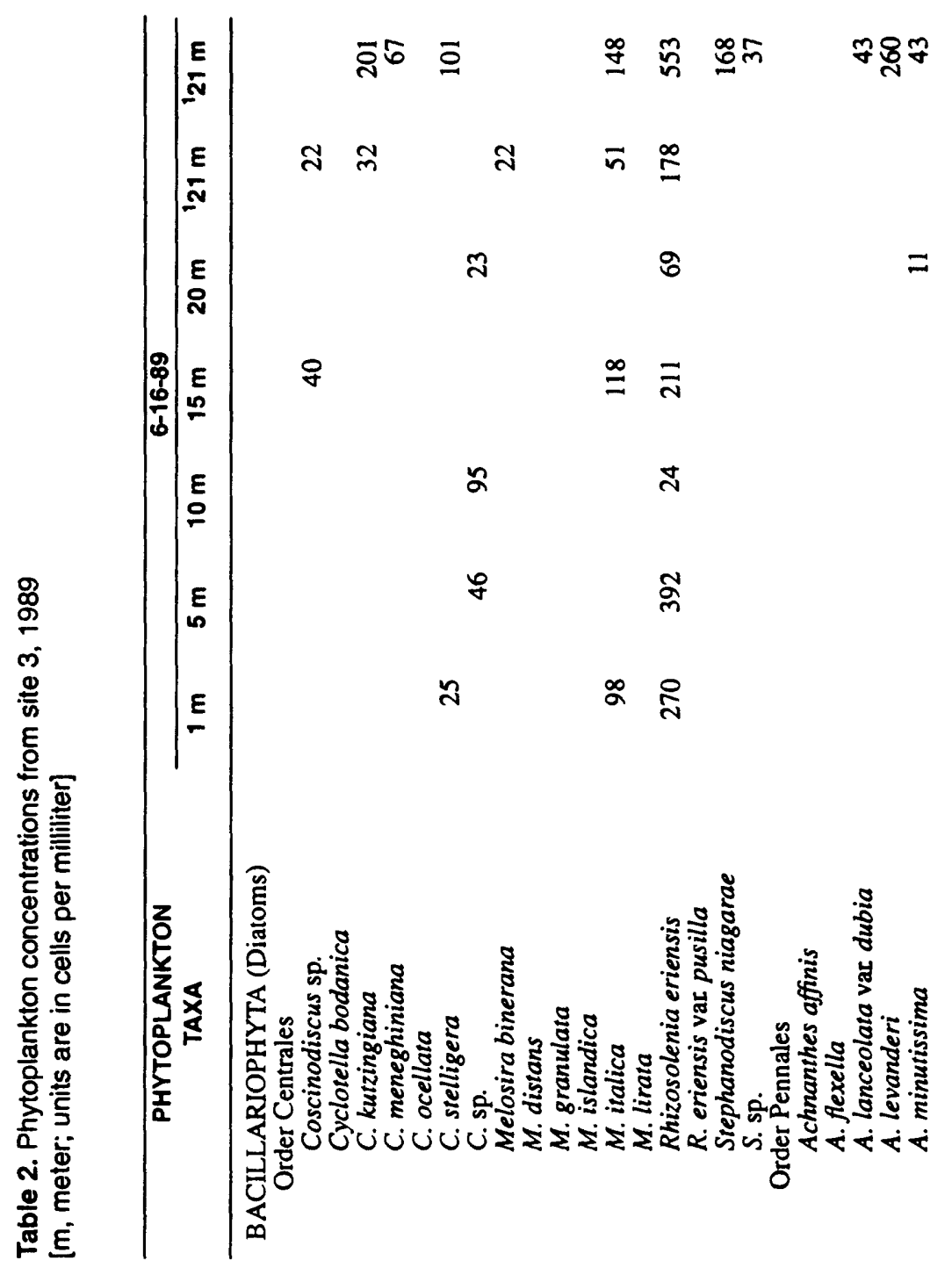




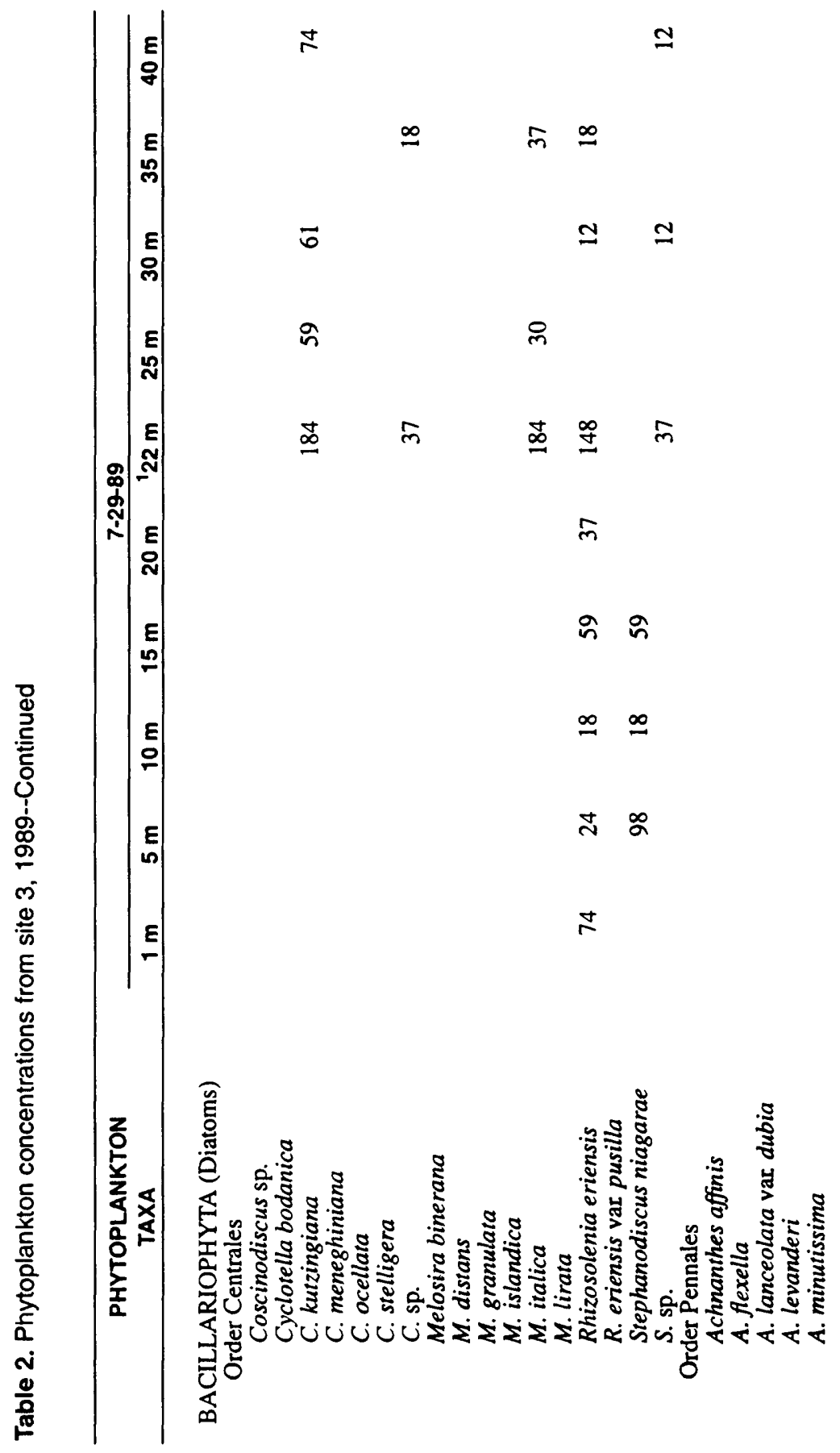




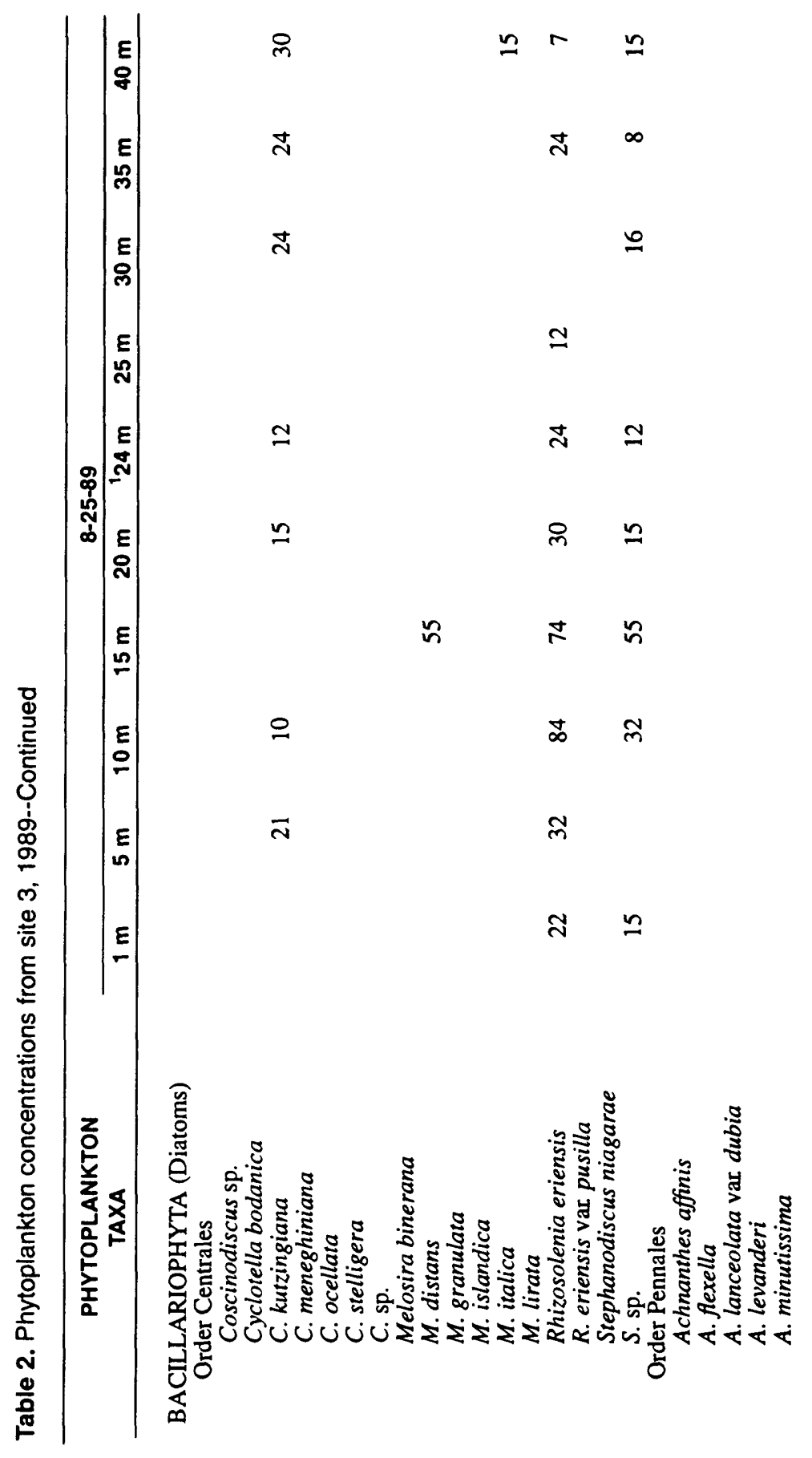




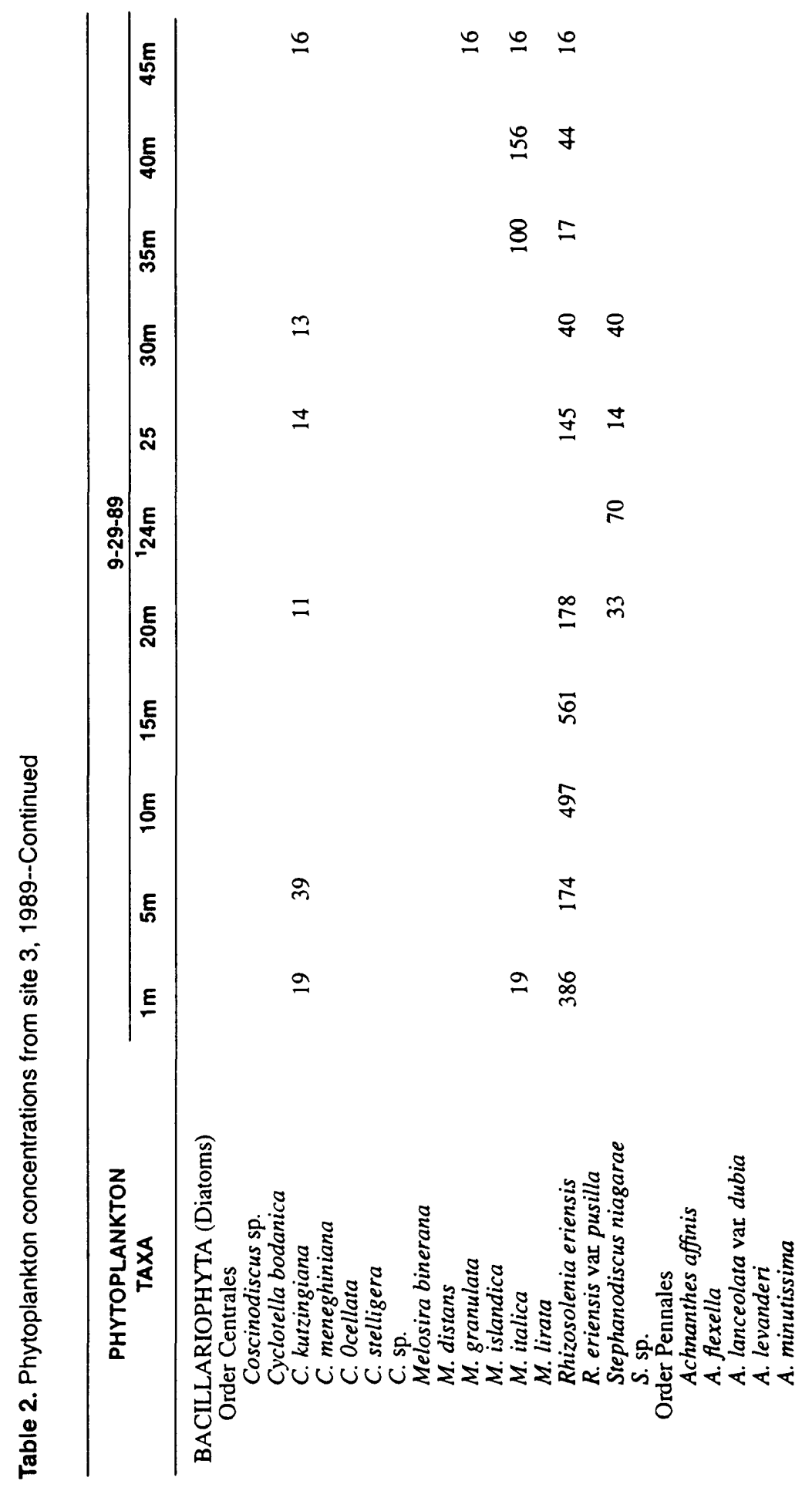




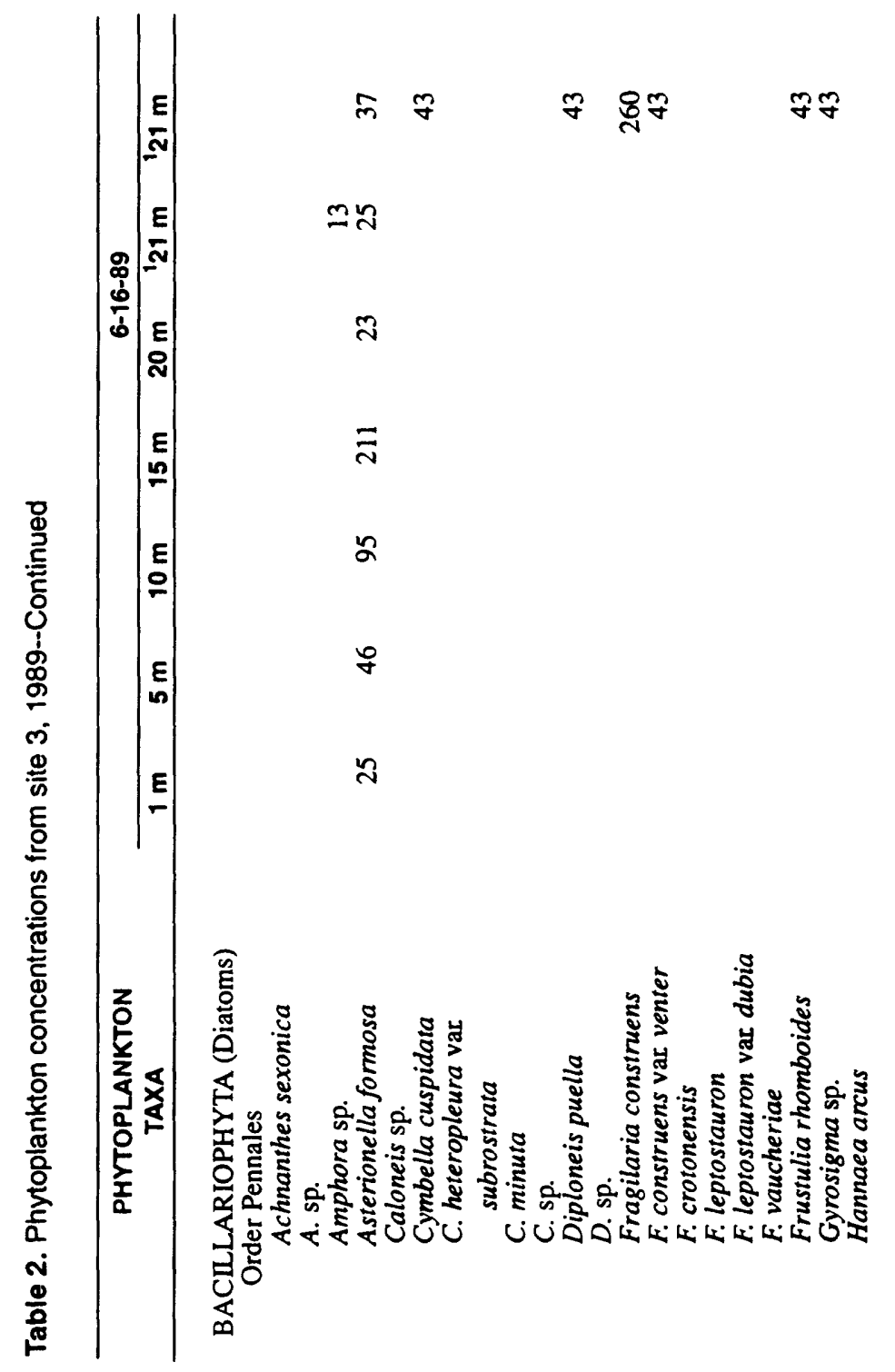




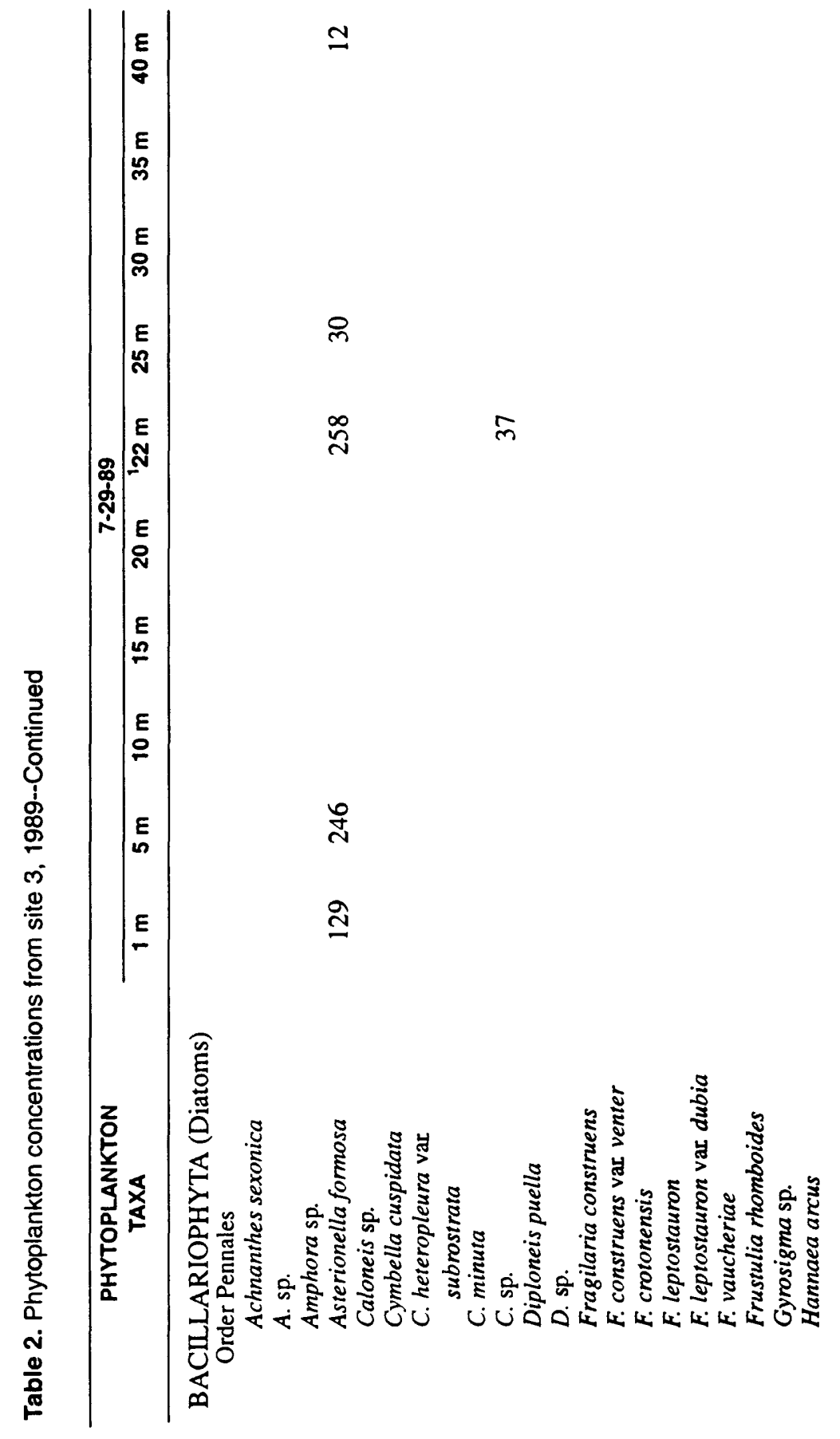




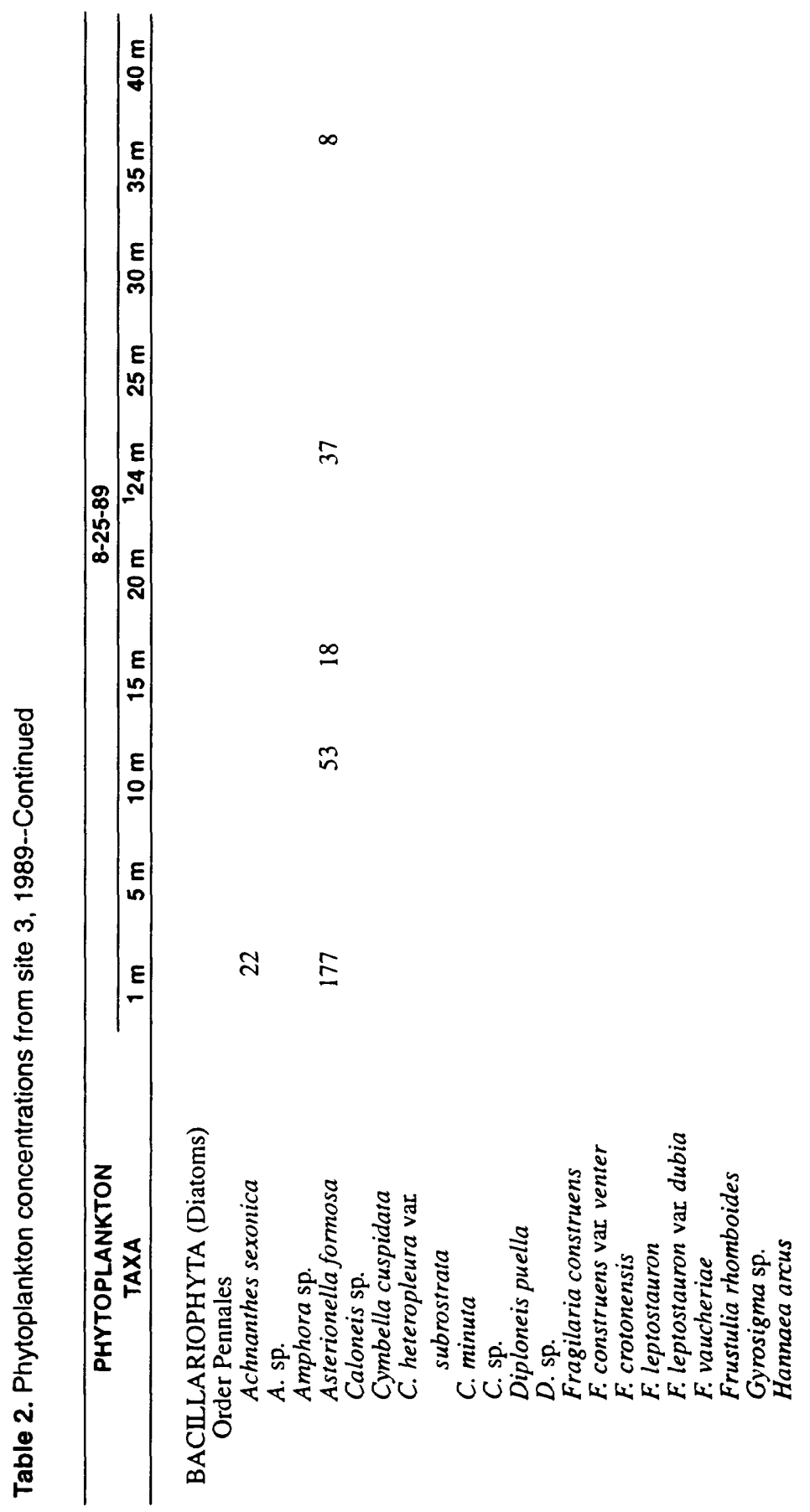




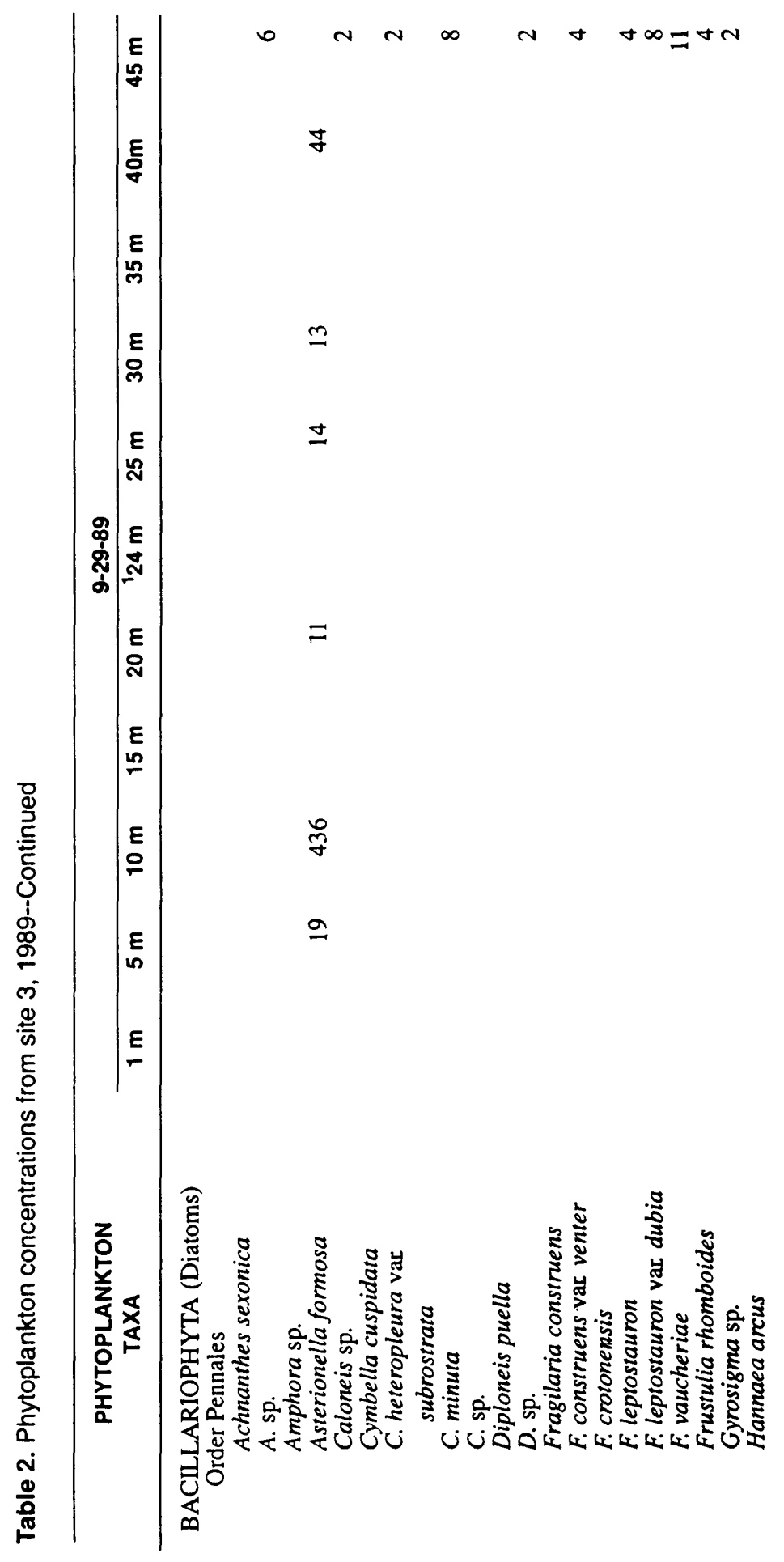




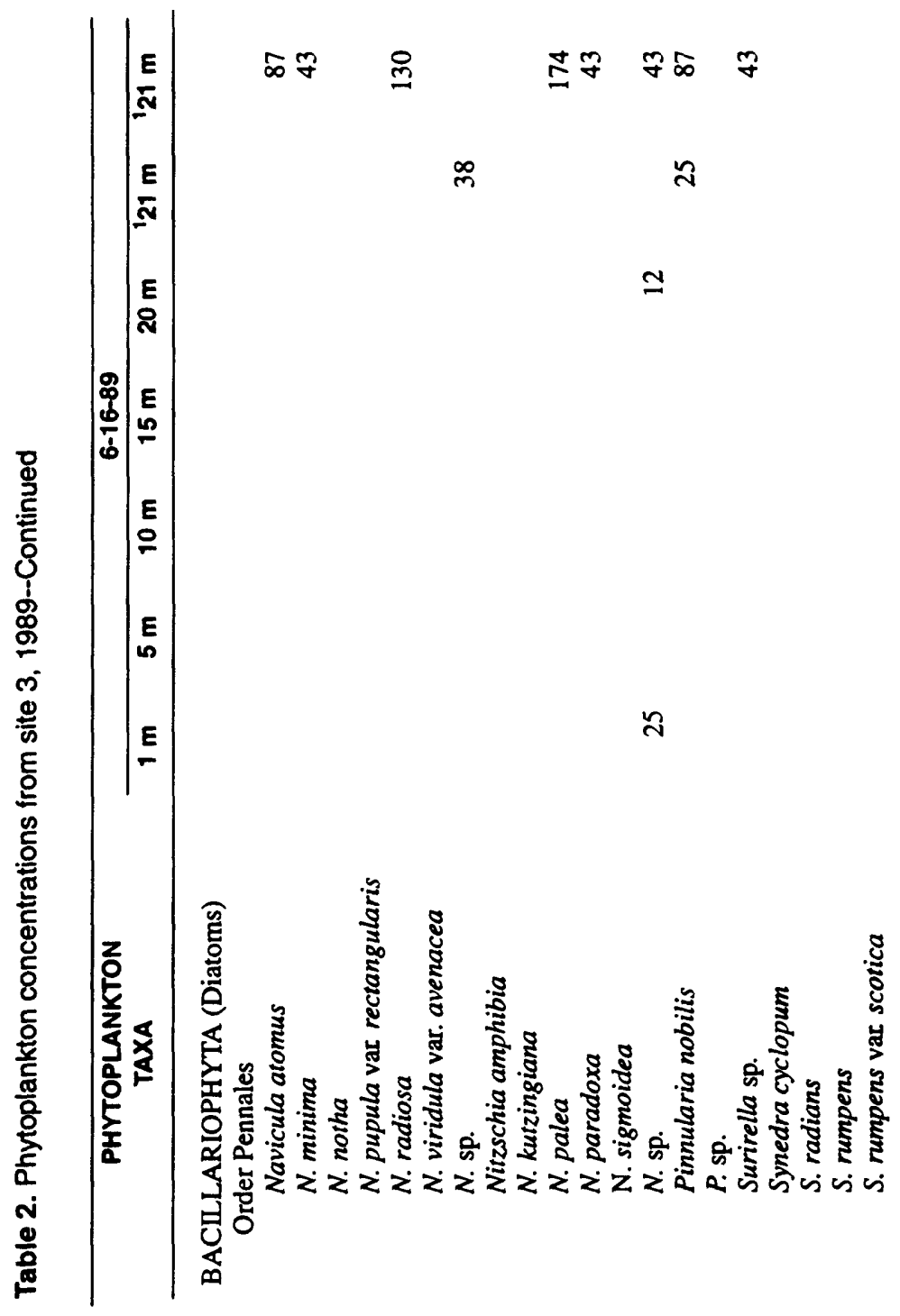




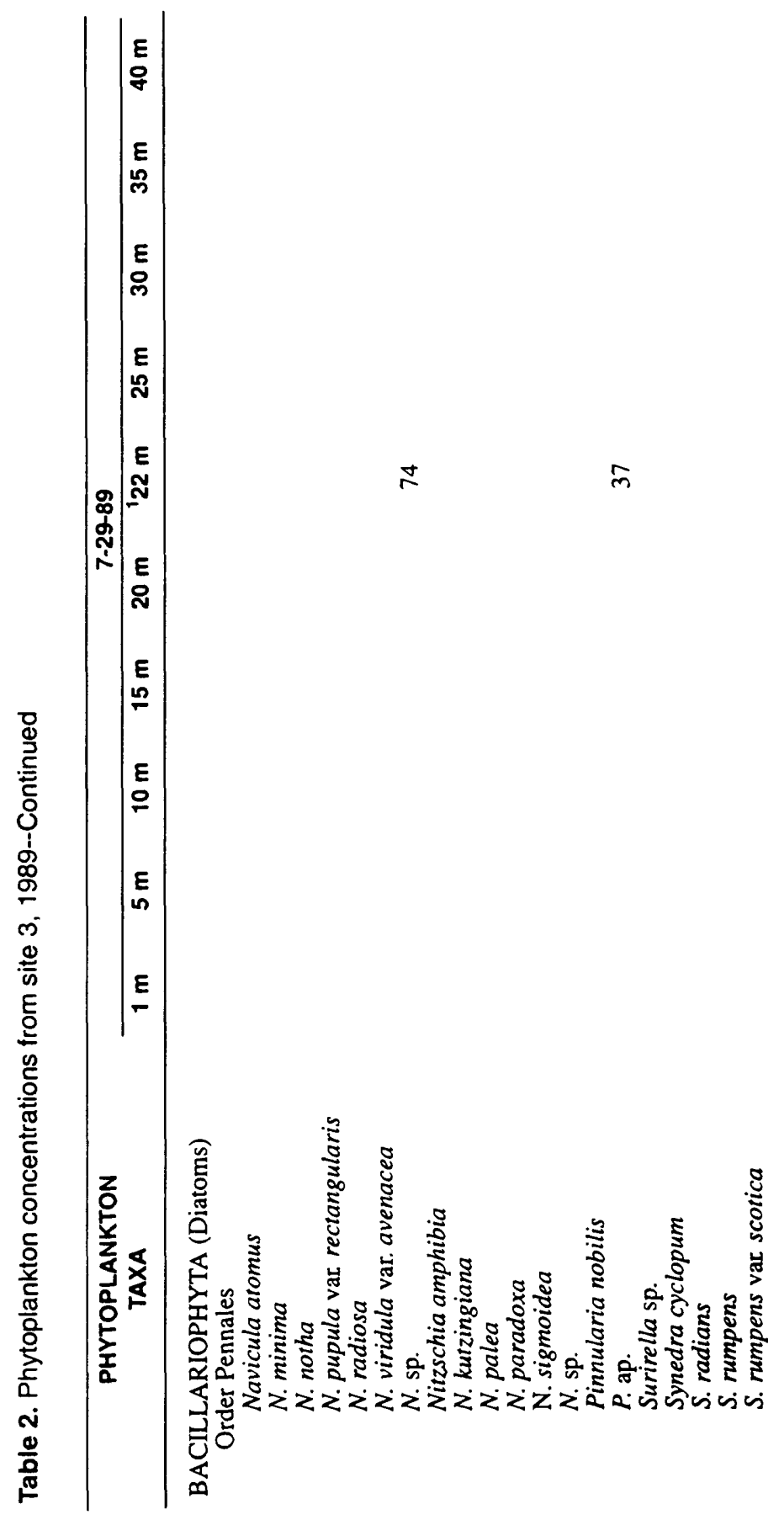




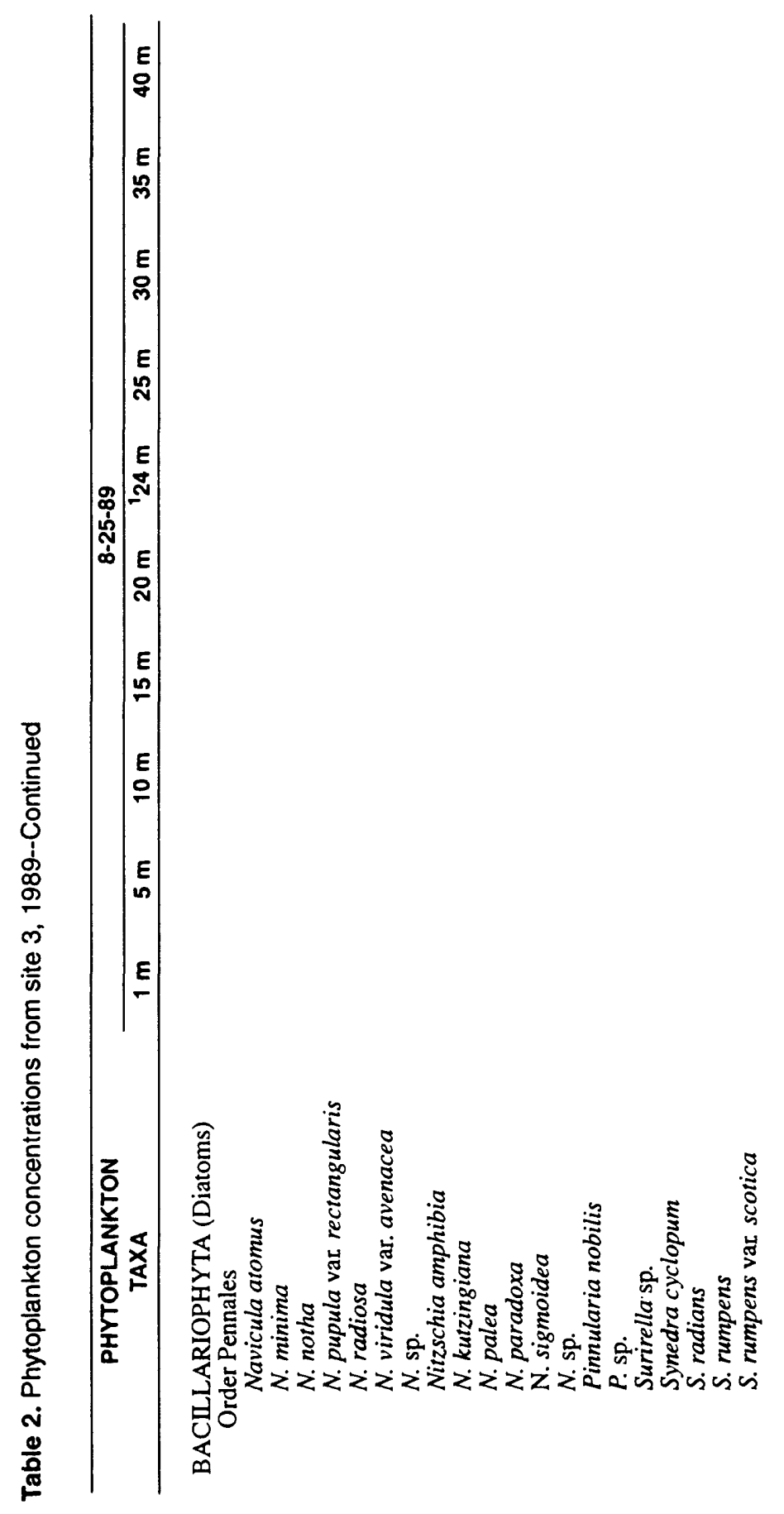




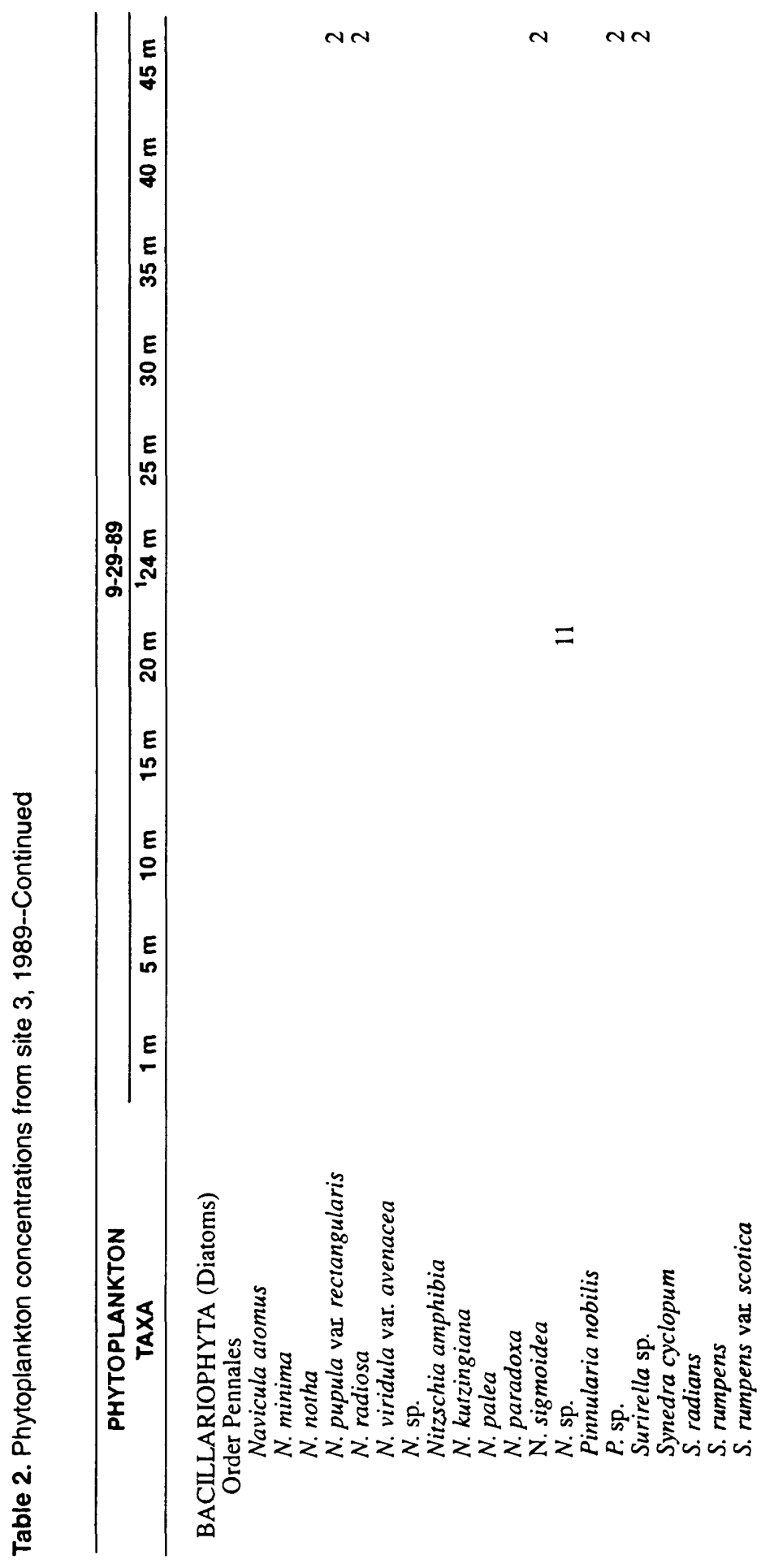




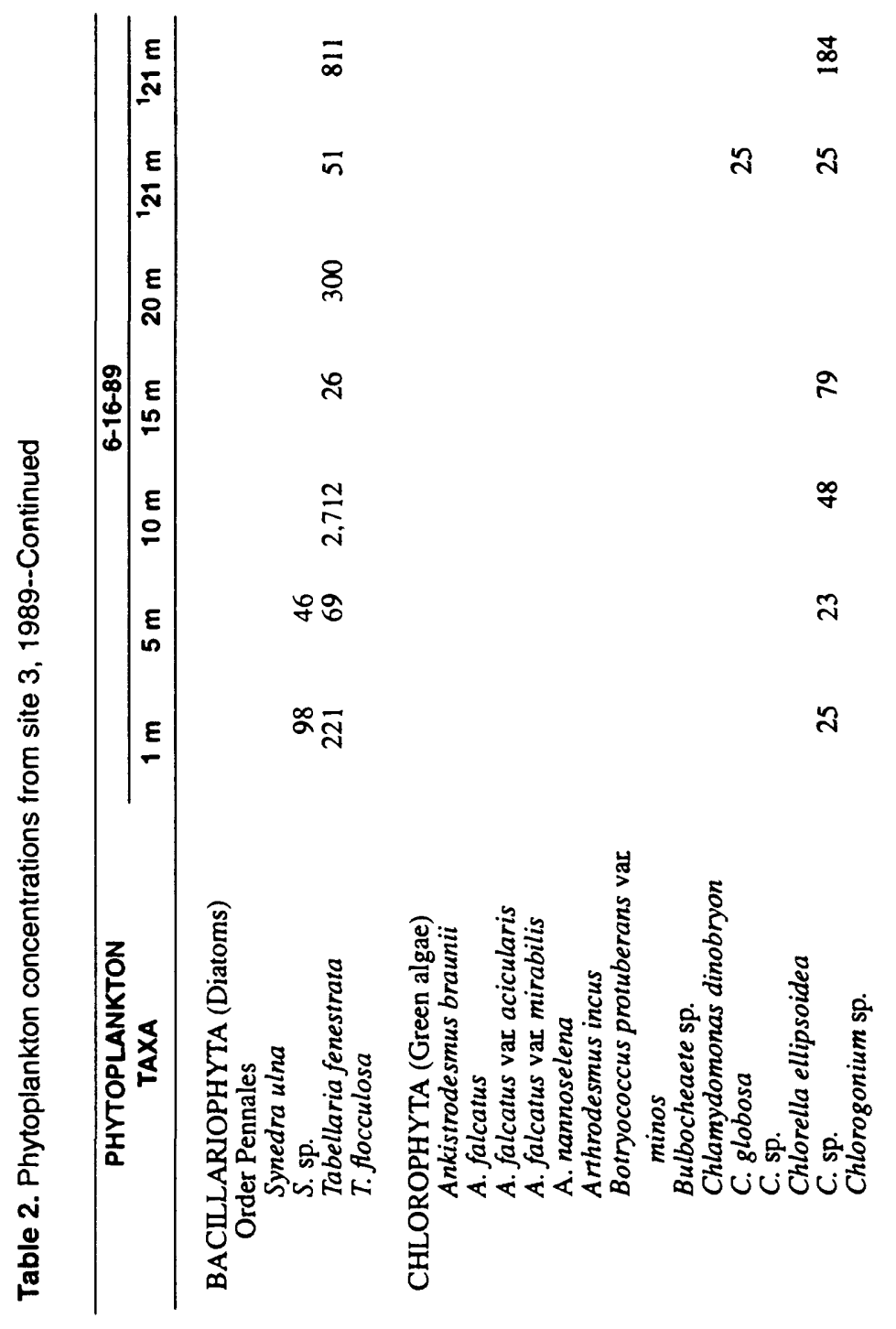




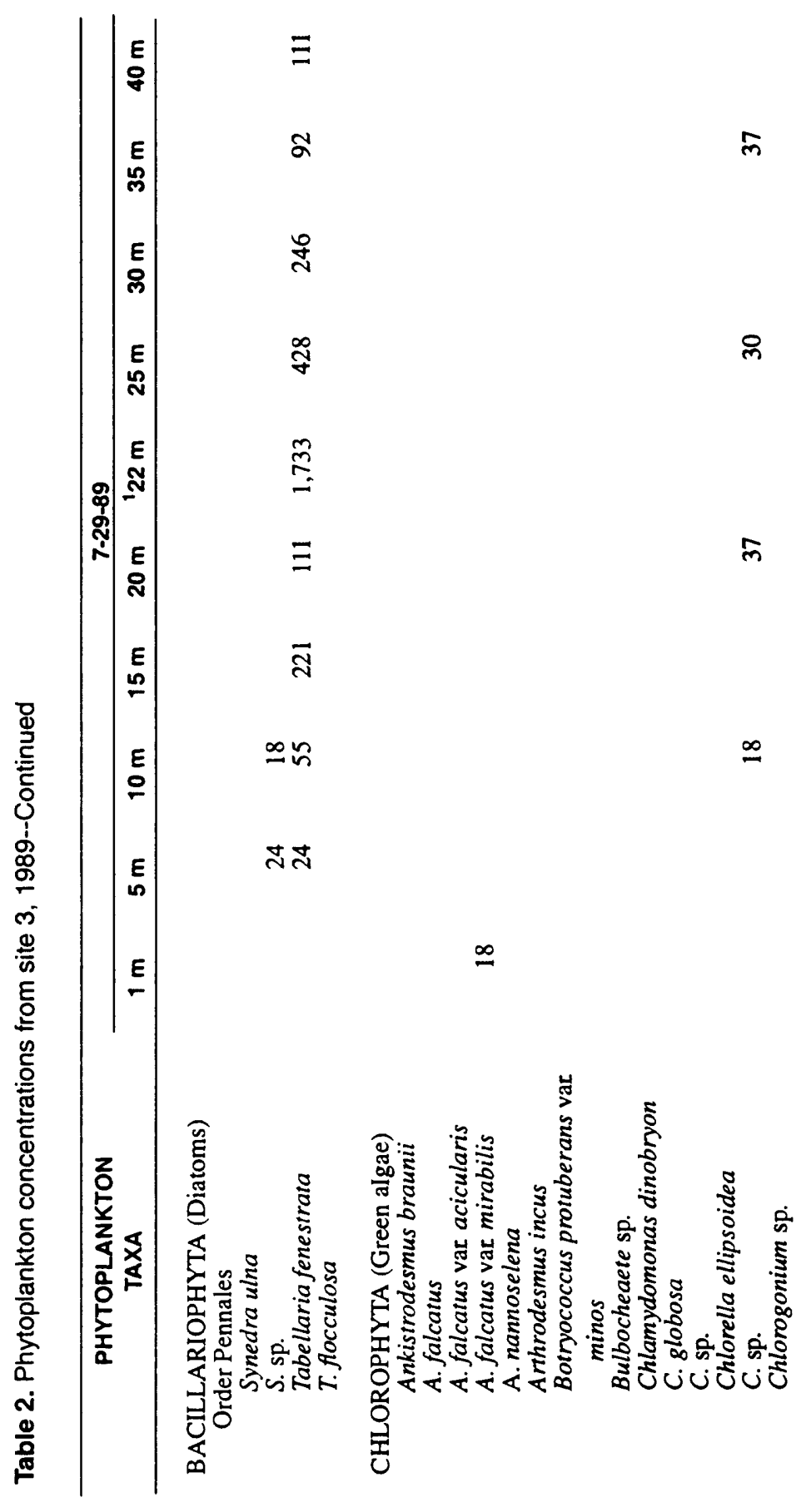




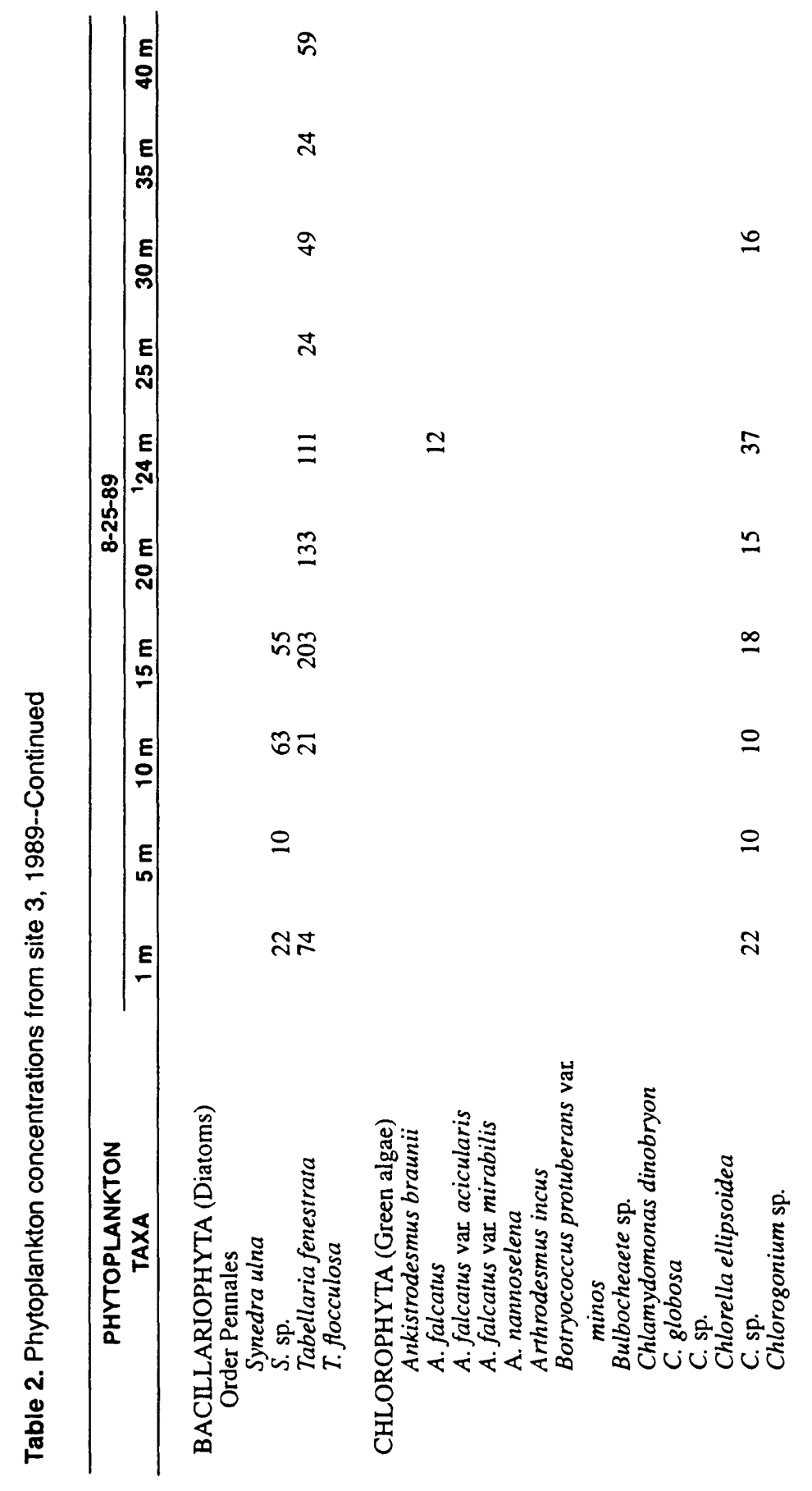




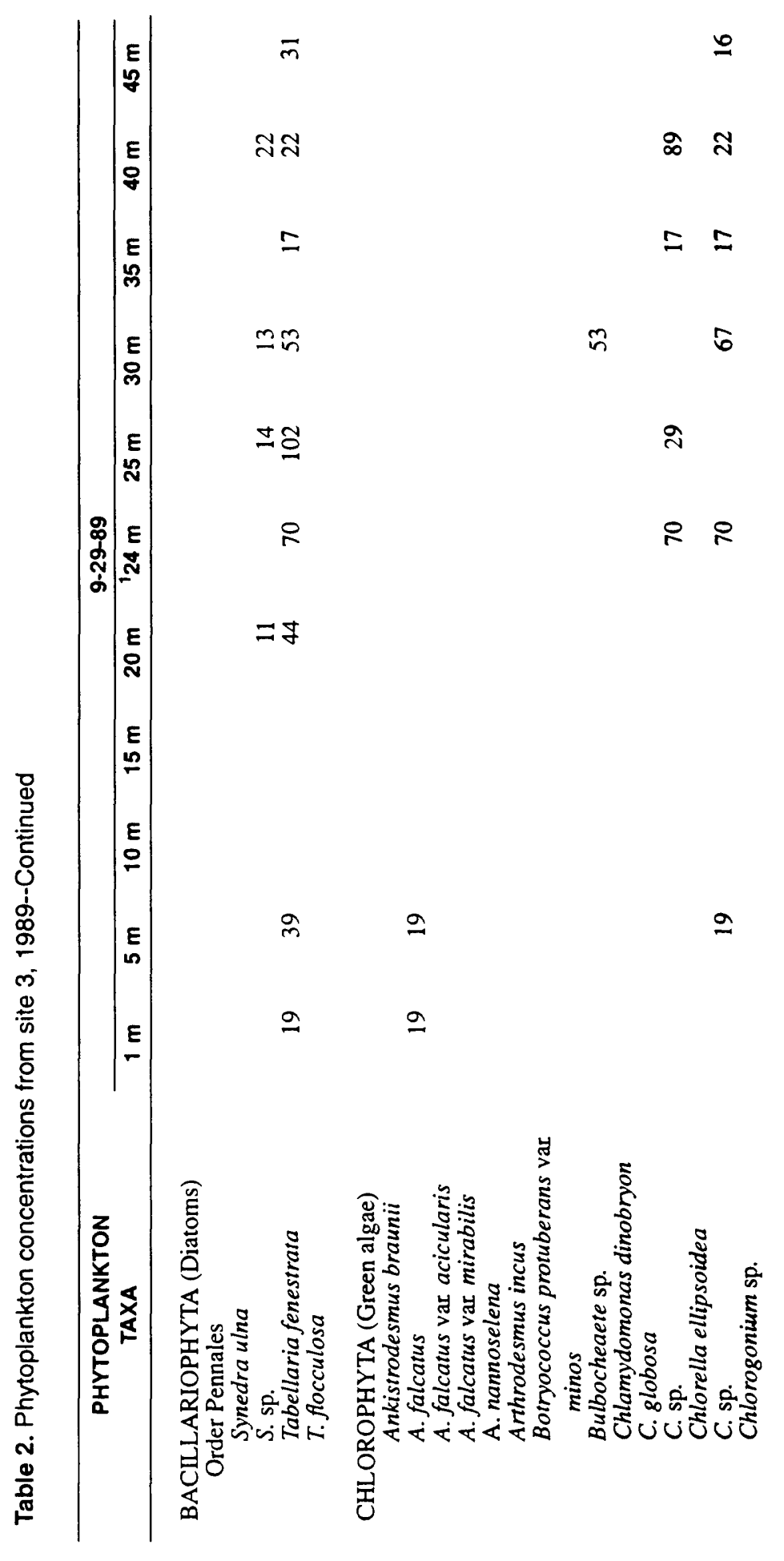




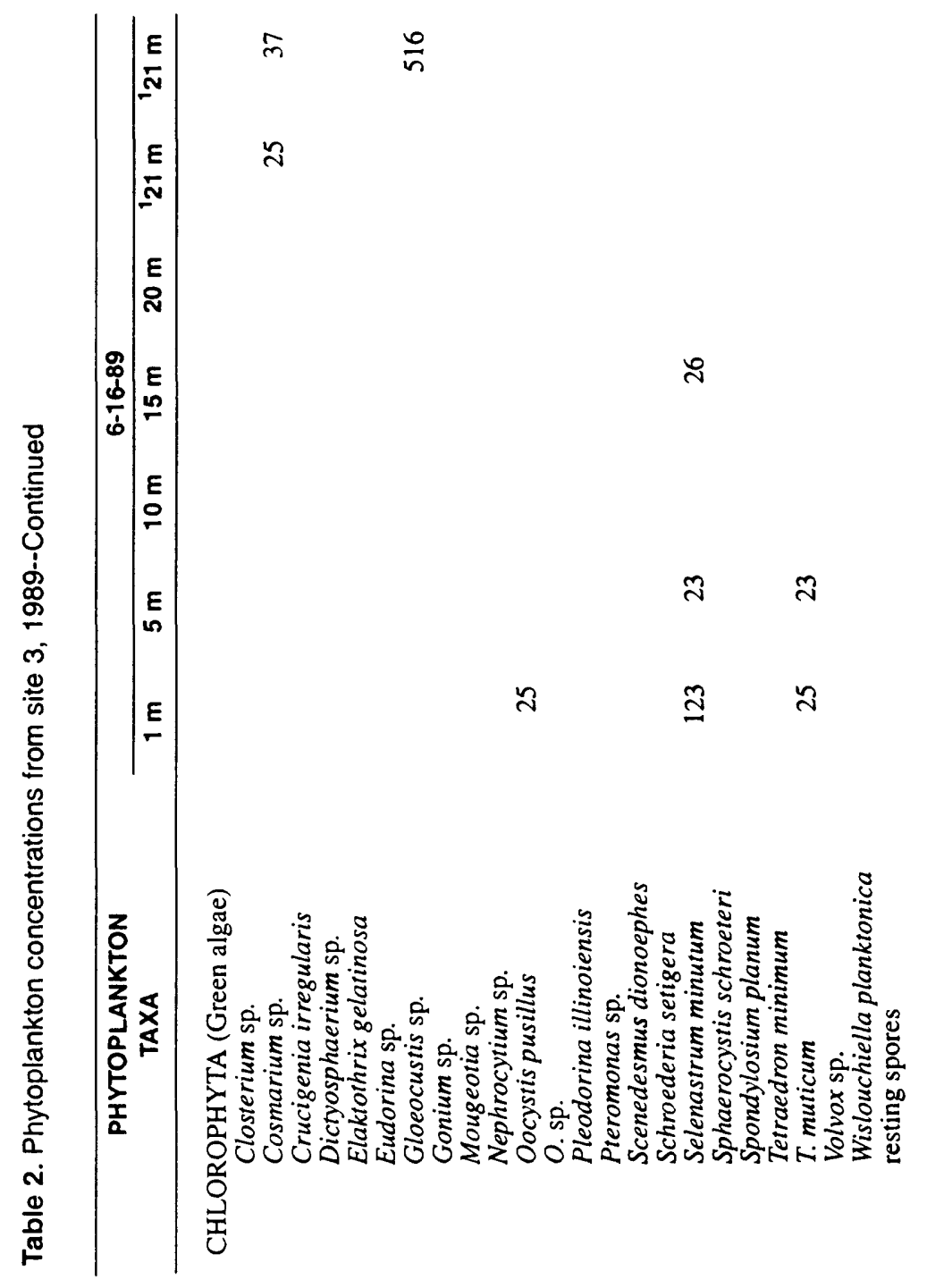




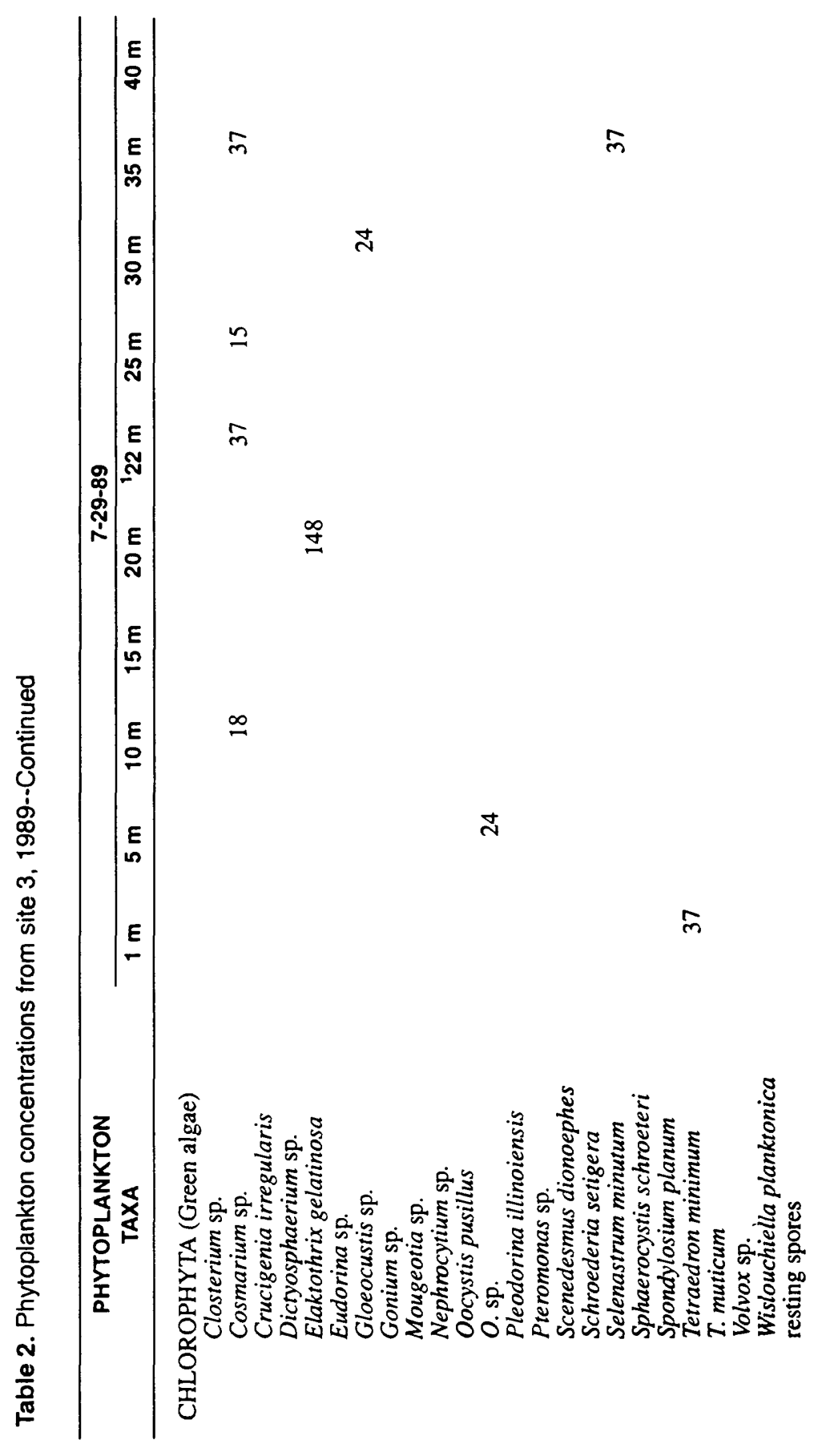




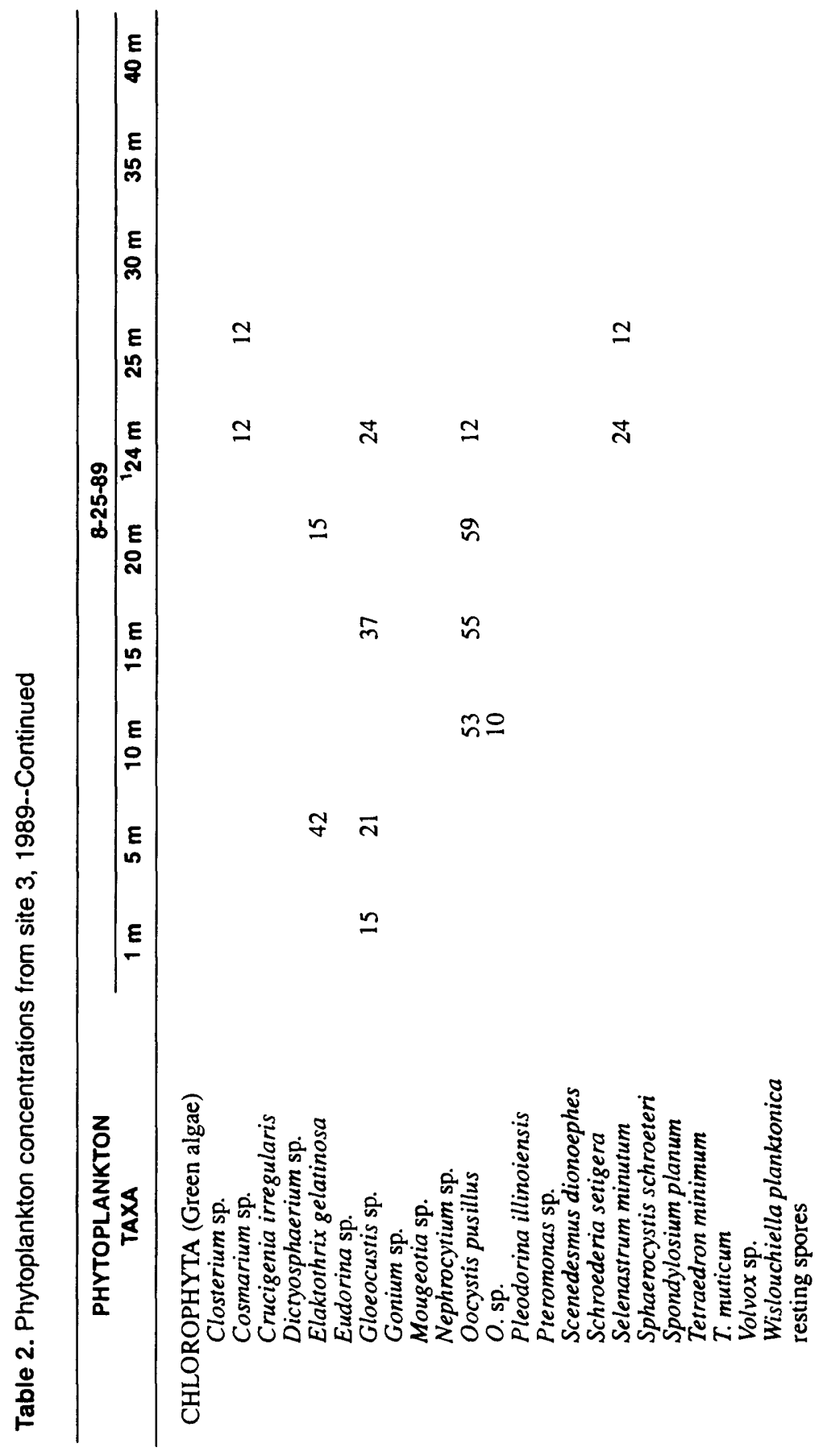




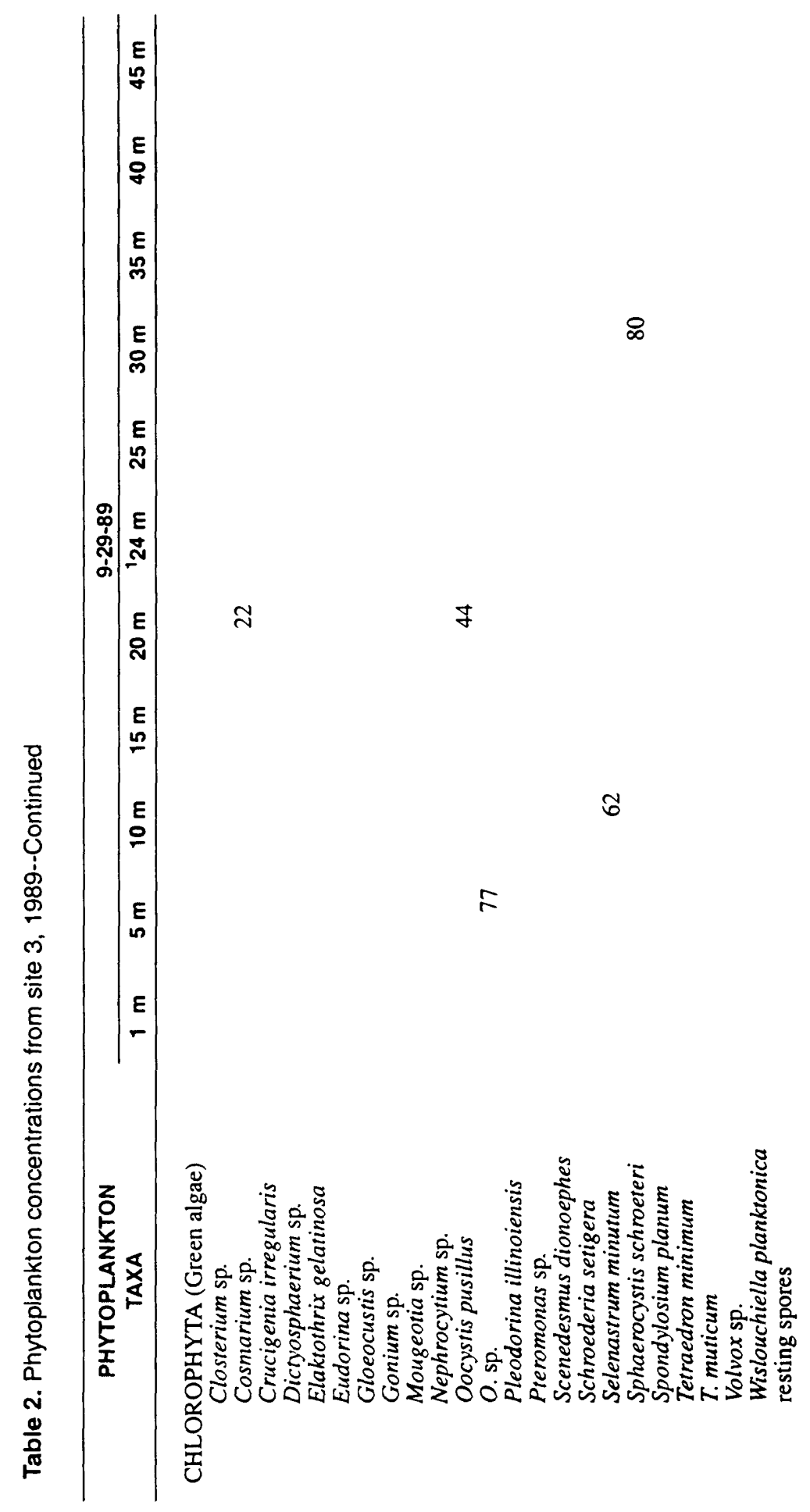




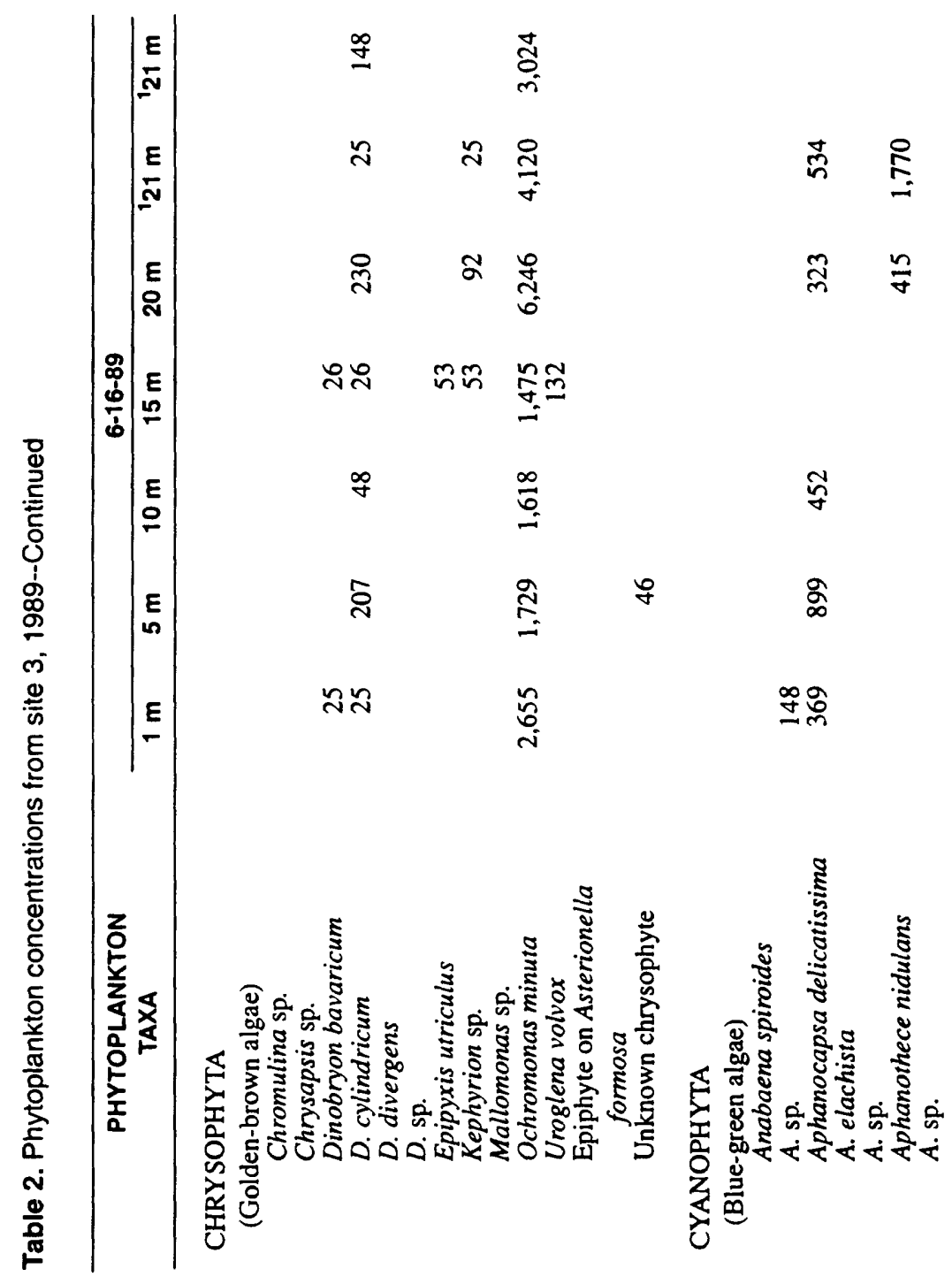




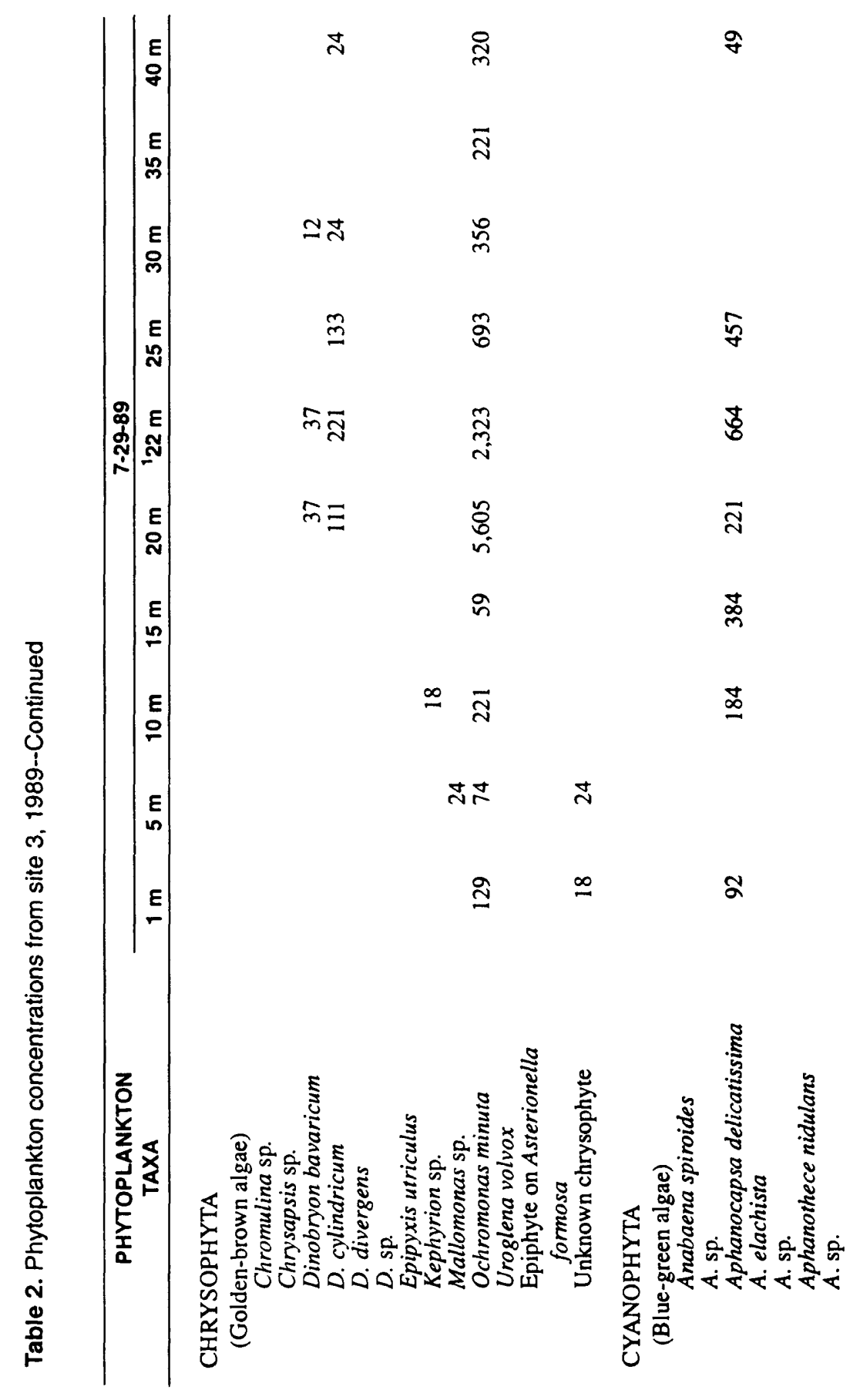




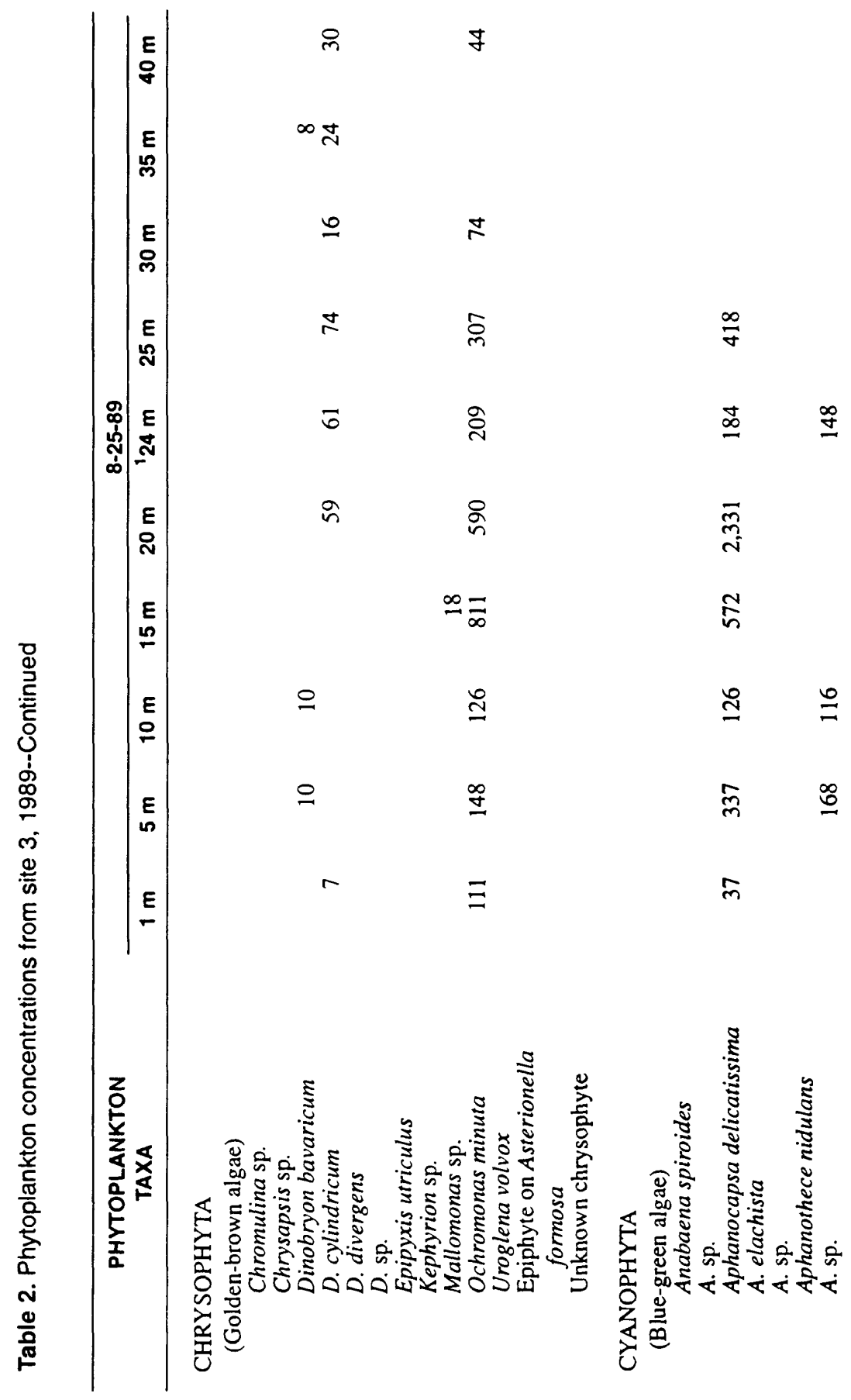




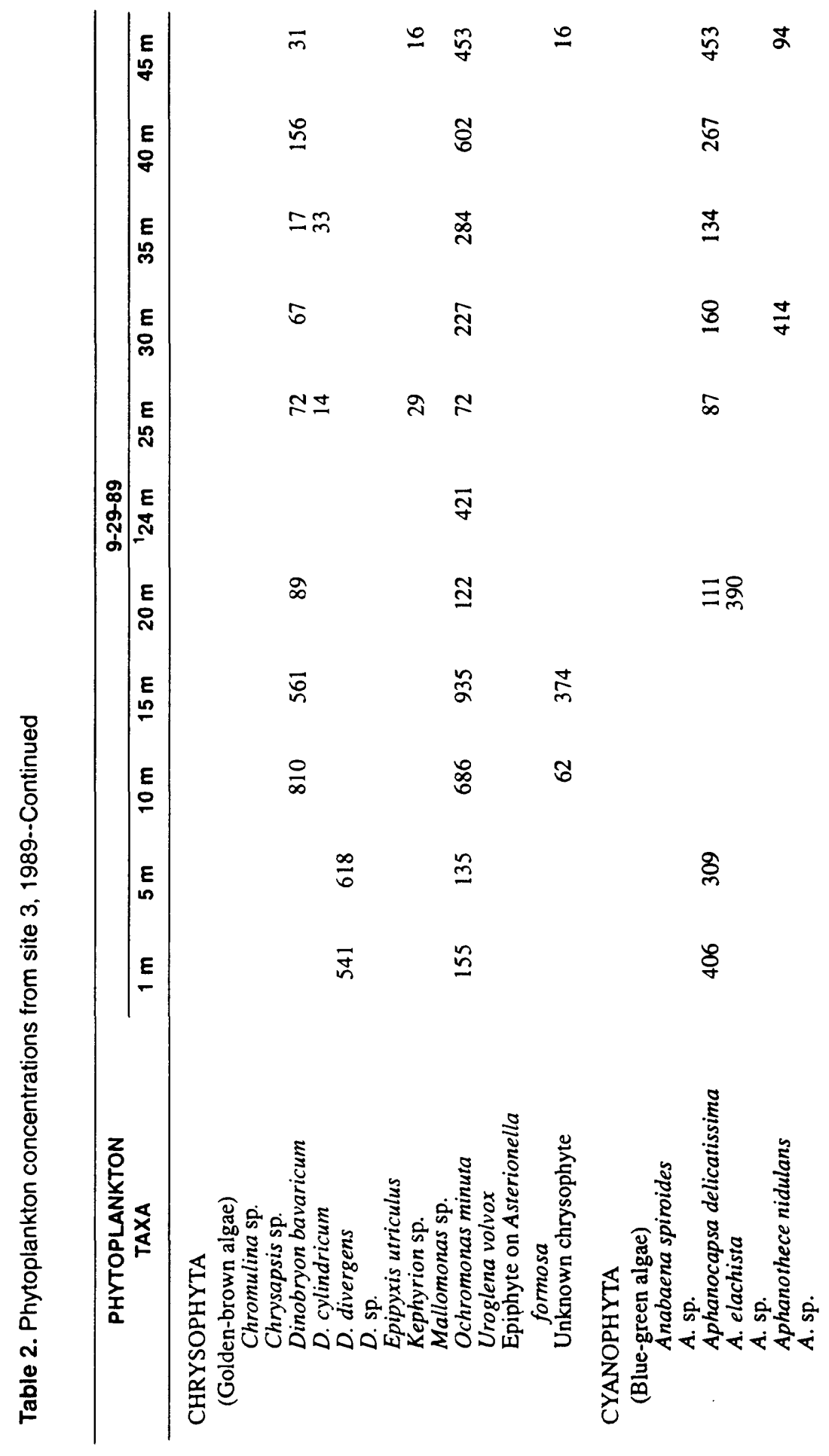




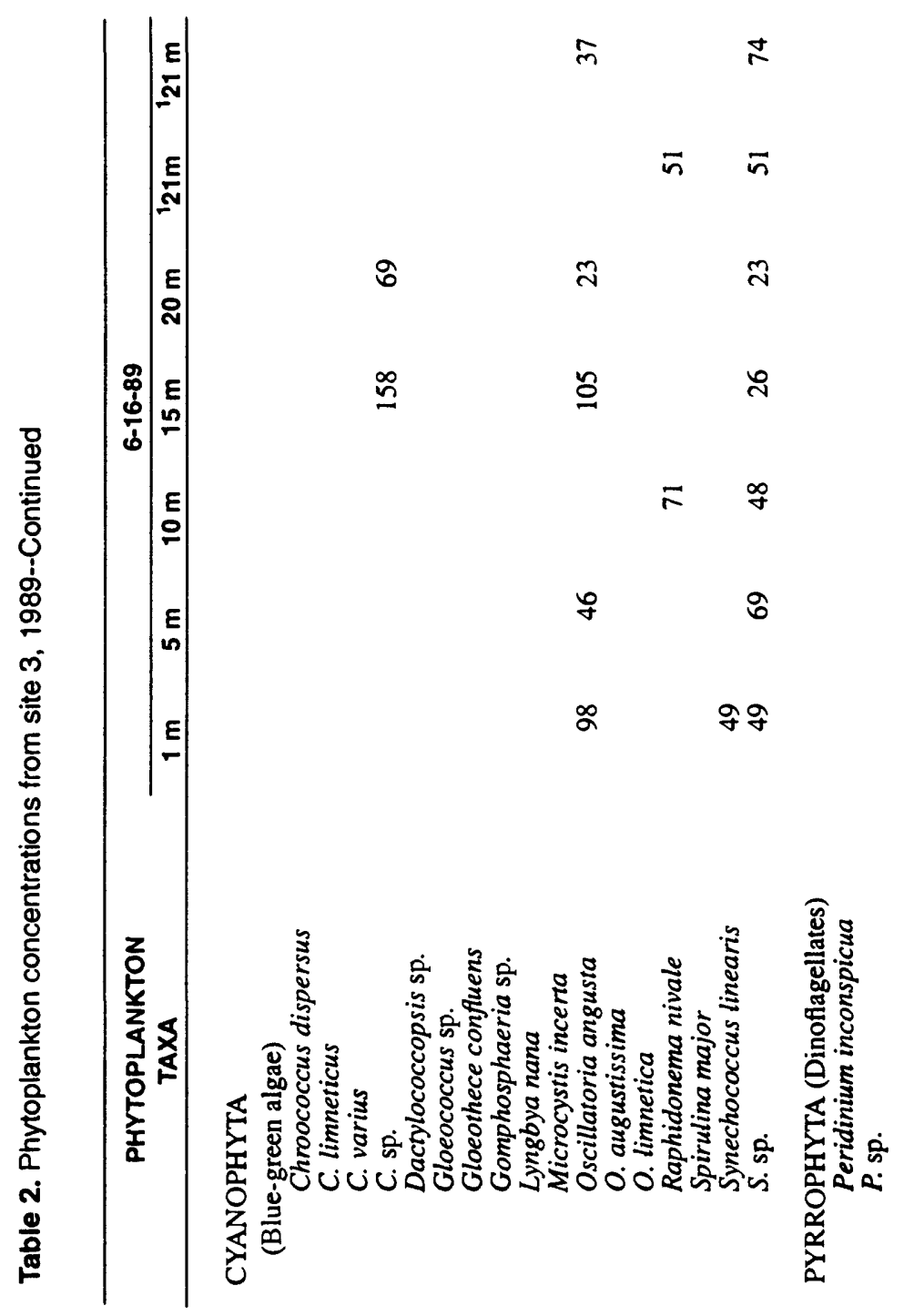




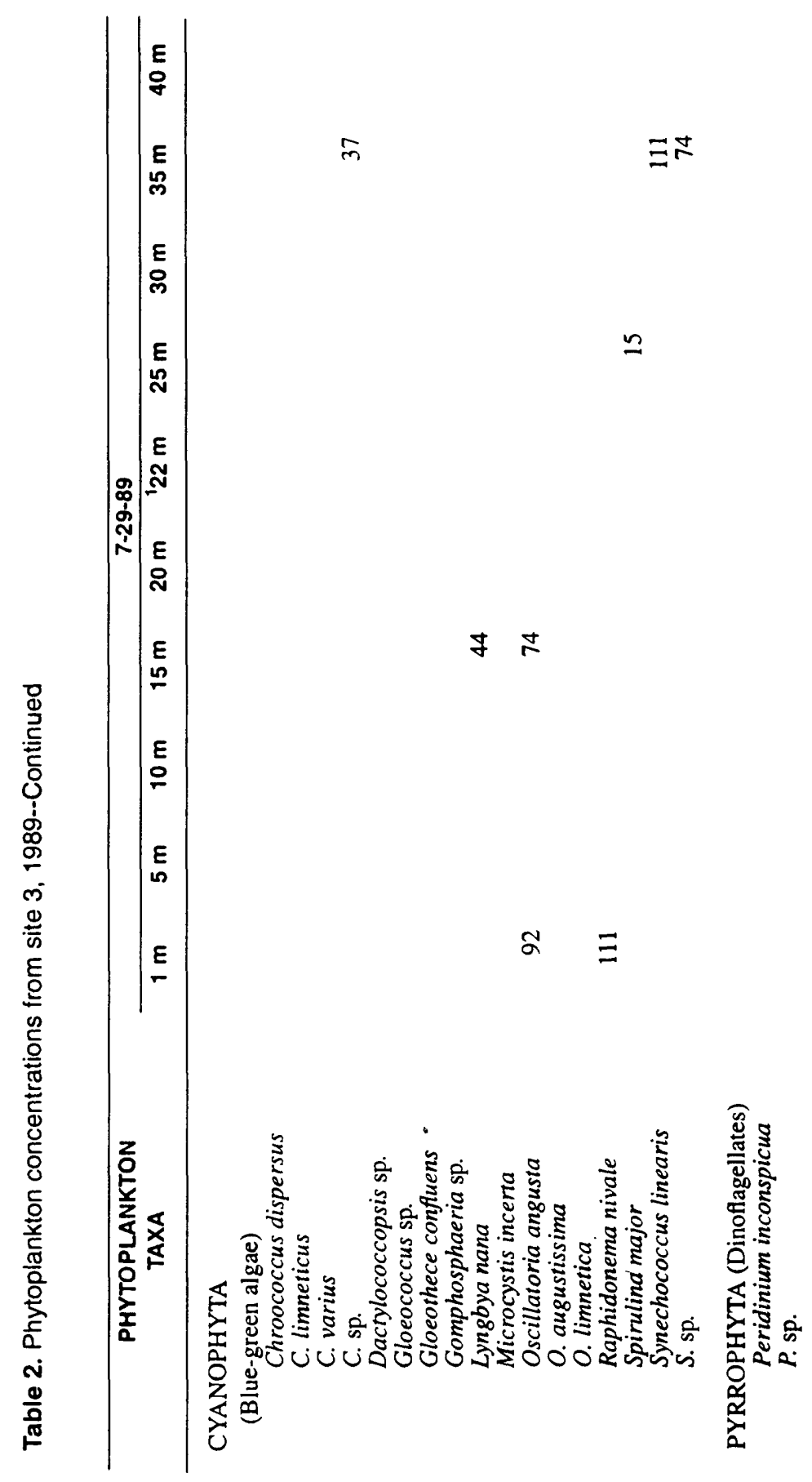

RESULTS 


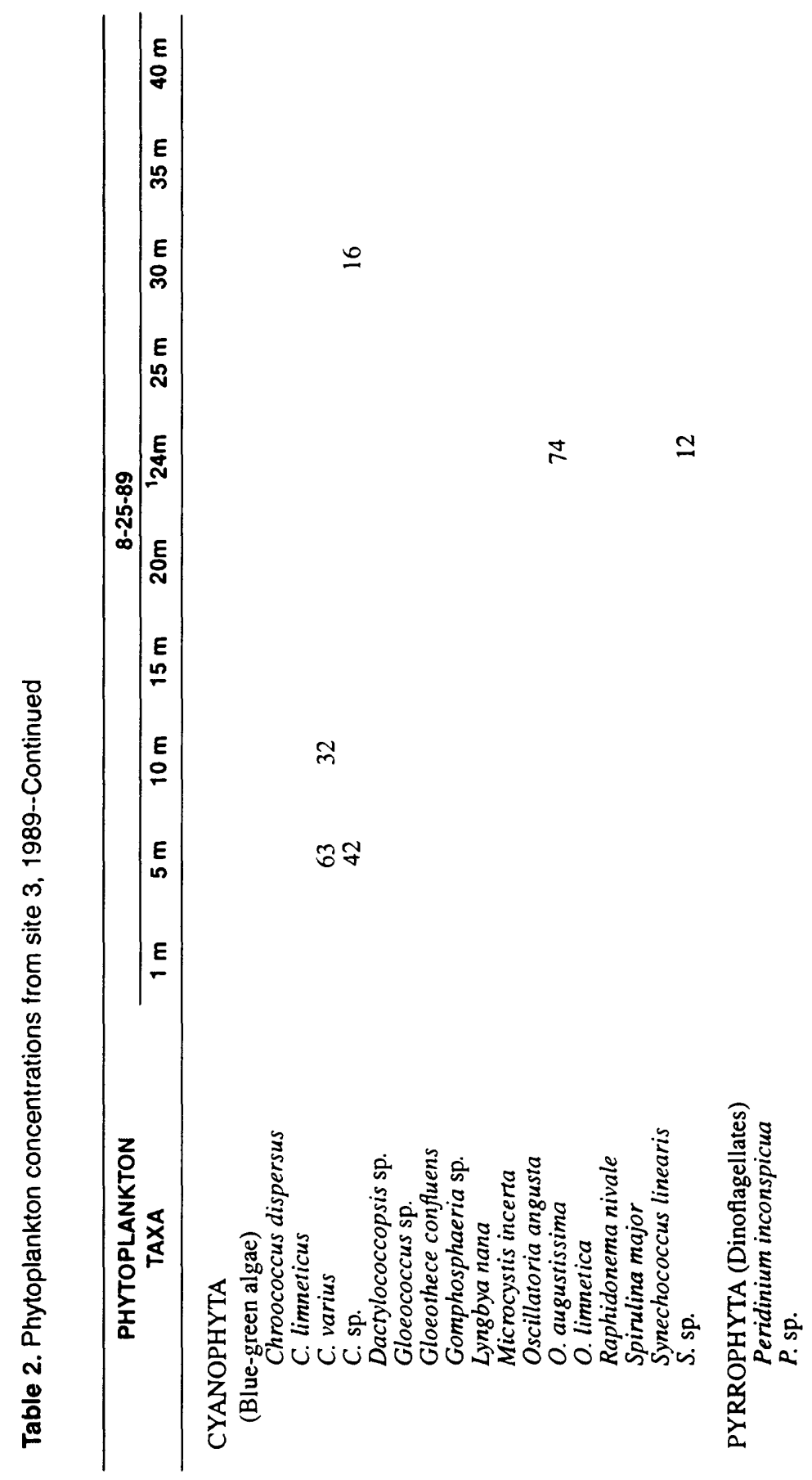




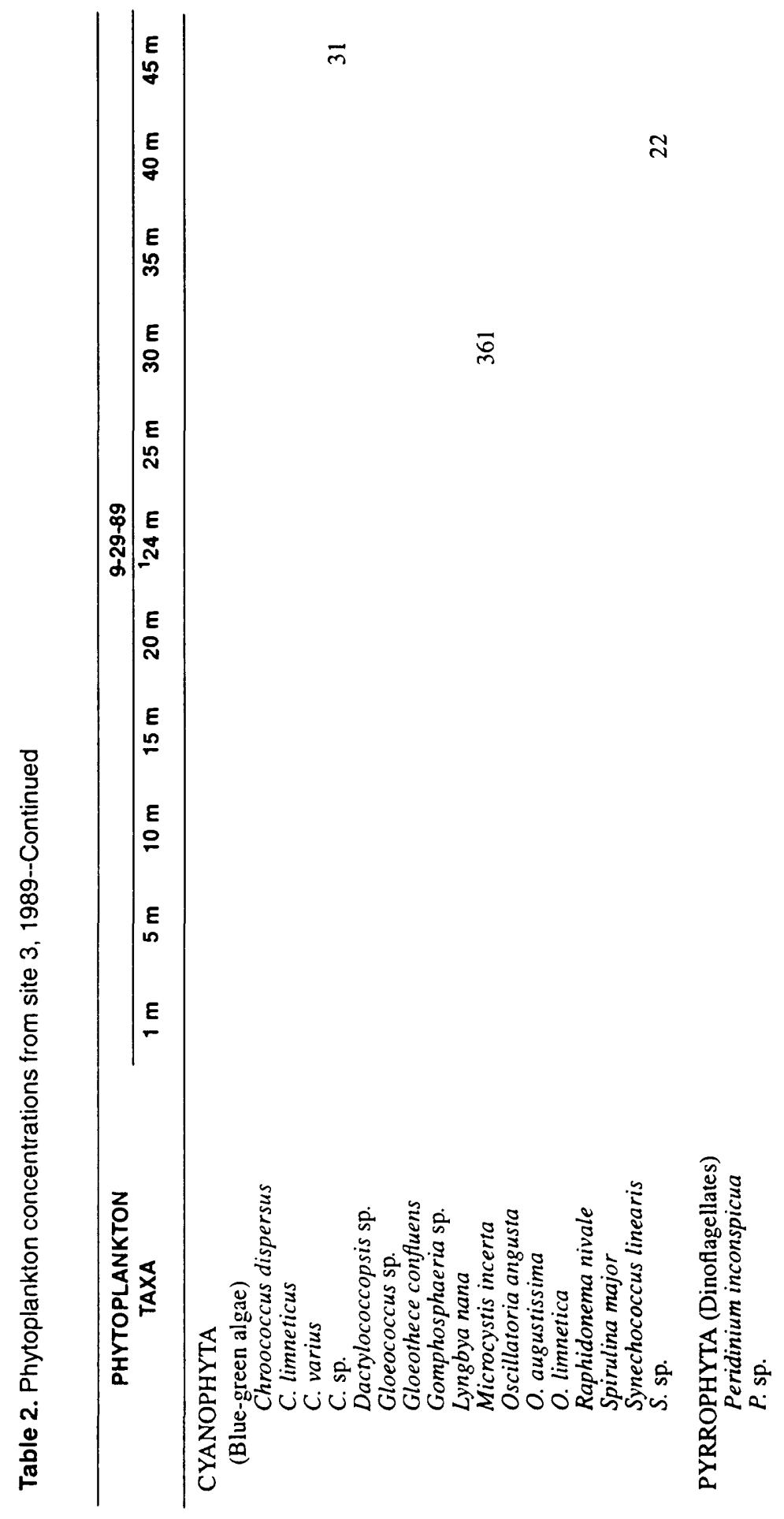



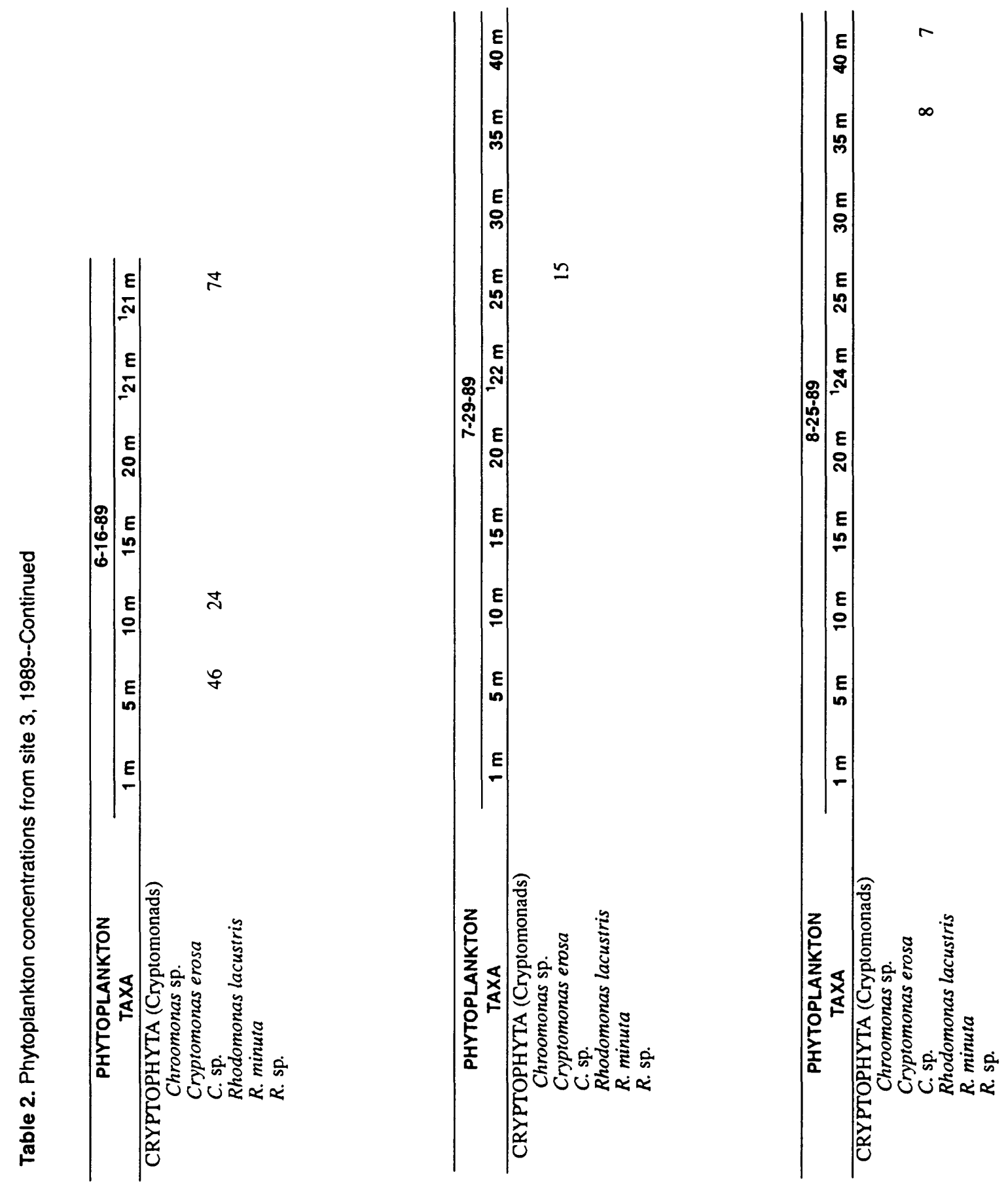


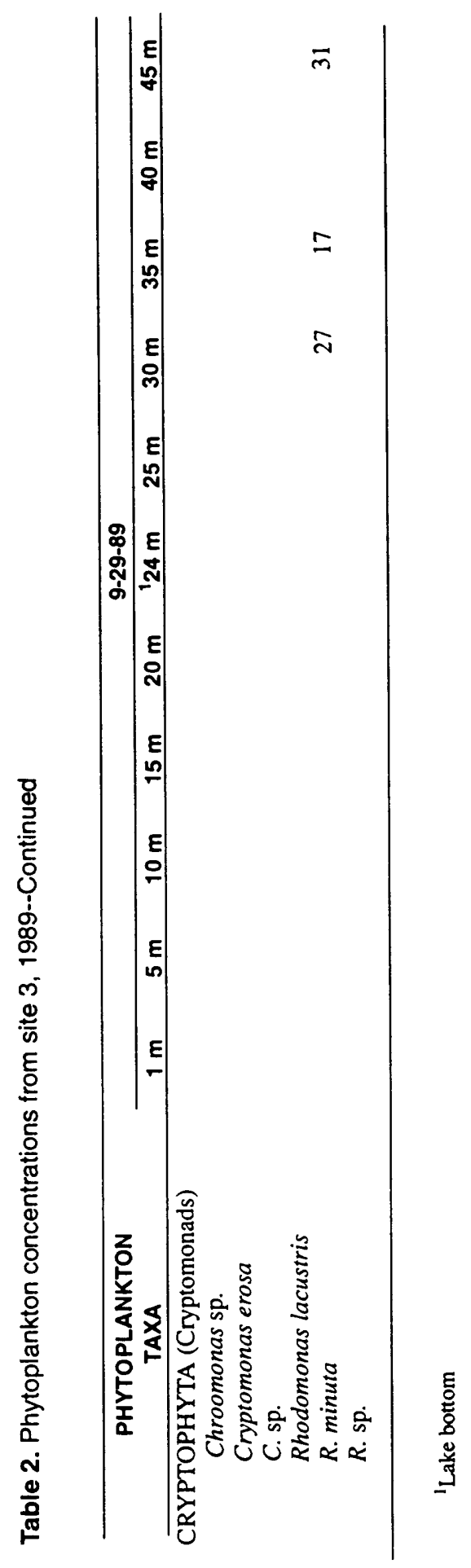

RESULTS 
ever, it never reached concentrations greater than 5,000 cells $/ \mathrm{mL}$. Other blue-green algae in Fremont Lake that cause nuisance blooms elsewhere are Oscillatoria and Microcystis, neither having the ability to fix nitrogen. While both were present in the 1989 samples, Microcystis was absent in the 1983-84 samples. The concentrations for both genera were low. The blue-green algae Aphanothece was abundant in the 1983-84 samples. Smith (1950, p. 561) reports that Aphanocapsa and Aphanothece have been considered synonyms of Anacystis, a notorious bloom-forming algae. Many blue-green algal blooms are local, responding to point sources of enrichment. Fortunately, no reports of excessive blue-green algal production have been recorded for Fremont Lake, although 13 genera were collected in this study.

A comparison of the presence or absence of phytoplankton between the 1983-84 and 1989 samples revealed that the more common and more abundant genera were present during both sampling periods (table 3 ). Twentythree genera present during 1989 were absent during 198384. Conversely, 28 genera of the 1983-84 samples were absent in the 1989 samples. These findings are not surprising, for the presence of a particular genera in the samples is a function of a number of environmental variables, such as water-column mixing, light, temperature, nutrient concentrations, relations with other algal species, and removal by zooplankton feeding. Table 3 , in juxtaposition with tables 1 and 2, will be of value to future investigators of Fremont Lake in assessing algal changes resulting from the activities of man.

Table 3. Presence or absence of phytoplankton genera, 1983-84 and 1989

[X, presence; -, absence]

\begin{tabular}{|c|c|c|}
\hline PHYTOPLANKTON GENERA & $1983-84$ & 1989 \\
\hline \multicolumn{3}{|l|}{ BACILLARIOPHYTA } \\
\hline \multicolumn{3}{|l|}{ (Diatoms) } \\
\hline Achnanthes & $\mathbf{X}$ & $\mathbf{X}$ \\
\hline Amphora & - & $\mathbf{X}$ \\
\hline Asterionella & $\mathbf{X}$ & $\mathbf{X}$ \\
\hline Caloneis & $\mathbf{X}$ & $\mathbf{X}$ \\
\hline Coscinodiscus & - & $\mathrm{X}$ \\
\hline Cyclotella & $\mathbf{X}$ & $\mathbf{X}$ \\
\hline Cymbella & - & $\mathbf{X}$ \\
\hline Diploneis & $\mathbf{X}$ & $X$ \\
\hline Fragilaria & $\mathbf{X}$ & $X$ \\
\hline Frustulia & - & $\mathrm{X}$ \\
\hline Gyrosigma & - & $\mathrm{X}$ \\
\hline Hannaea & $\mathbf{X}$ & - \\
\hline Melosira & $\mathbf{X}$ & $\mathbf{X}$ \\
\hline Navicula & $\mathbf{X}$ & $\mathbf{X}$ \\
\hline Nitzschia & $\mathbf{X}$ & $\mathbf{X}$ \\
\hline Pinnularia & $\mathbf{X}$ & $\mathbf{X}$ \\
\hline Rhizosolenia & $\mathbf{X}$ & $\mathbf{X}$ \\
\hline Stephanodiscus & - & $\mathbf{X}$ \\
\hline Surirella & - & $\mathbf{X}$ \\
\hline Synedra & $\mathbf{X}$ & $\mathbf{X}$ \\
\hline Tabellaria & $\mathbf{X}$ & $\mathbf{X}$ \\
\hline \multicolumn{3}{|l|}{ CHLOROPHYTA (Green algae) } \\
\hline Ankistrodesmus & $\mathbf{X}$ & $\mathbf{X}$ \\
\hline Arthrodesmus & $\mathbf{X}$ & - \\
\hline Botryococcus & $\mathbf{X}$ & - \\
\hline Bulbochaete & - & $\mathbf{X}$ \\
\hline
\end{tabular}

Table 3. Presence or absence of phytoplankton genera, 1983-84 and 1989--Continued

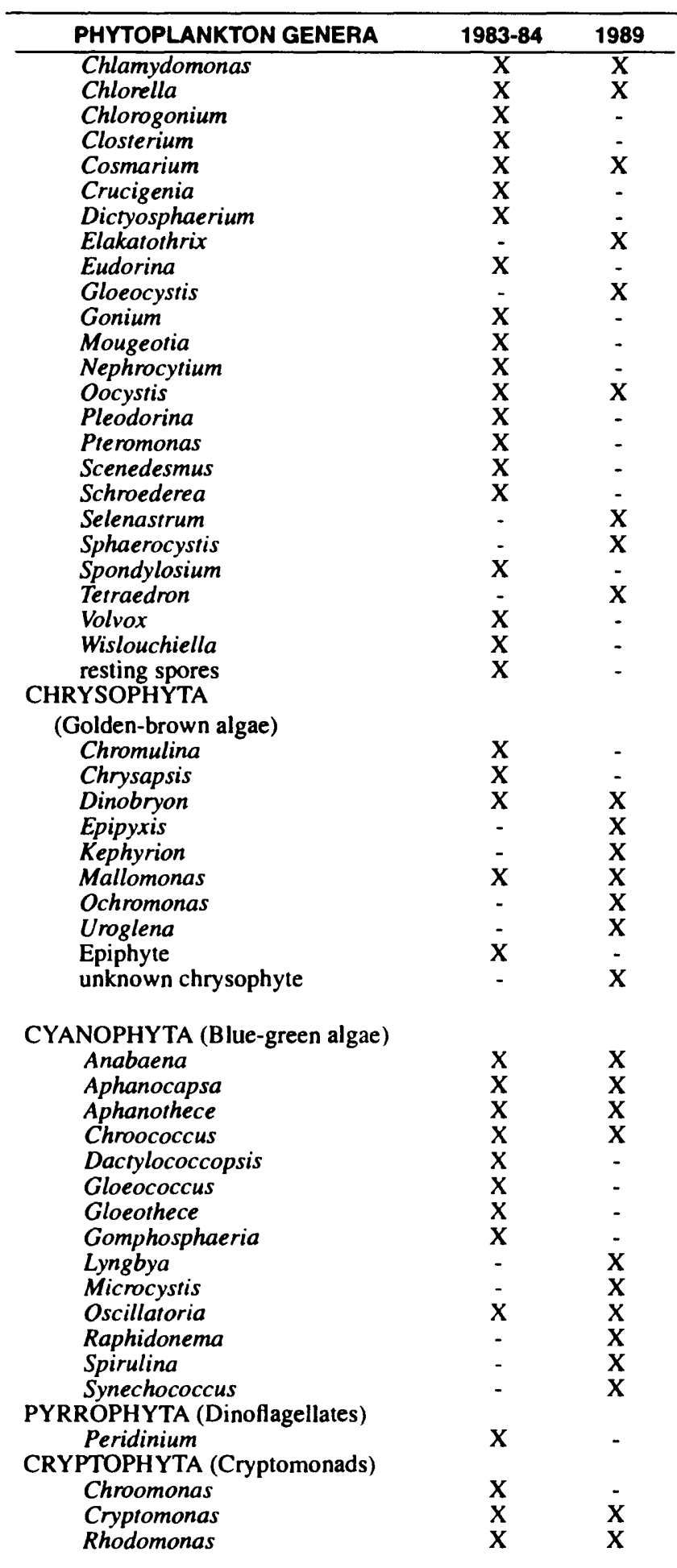

An objective of the 1989 sampling program was to determine the cause of taste and odor in the water supply of Pinedale, Wyoming. Sampling during 1989 was conducted near the water-supply intake, which is near the lake outlet (site 3 in fig. 1; see also fig. 2B). Although the depth near the 
inlet is about $24 \mathrm{~m}$, samples were collected to depths of 45 $m$ by extending the sampling site to a nearby location where the depth was $50 \mathrm{~m}$. Several genera of algae have been identified as causing severe taste and odor problems in water (Palmer, 1962; American Public Health Association and others, 1985). In Fremont Lake, 24 genera of phytoplankton were identified that have the potential of causing taste and odor (table 4). Twenty genera were identified during 1983-84 and 19 during 1989 that could cause taste and odor problems. The abundant taste and odor genera during 1984 were Tabellaria, a diatom; Volvox, a green algae; Dinobryon, a golden-brown algae; and Aphanocapsa and Aphanothece, two blue-green algae. Volvox was especially abundant during August 1984, at about 20,000 cells $/ \mathrm{mL}$. During 1989, Asterionella, Cyclotella, and Tabellaria, all diatoms, were relatively abundant, especially Tabellaria. Dinobryon (a golden brown) and Aphanocapsa (a blue green) also were relatively abundant.

We have no direct evidence of phytoplankton being responsible for the taste and odor problem in the Pinedale water supply. Our samples would indicate that by concentration alone, if any given genera were responsible during 1989 it probably would be Tabellaria, which was somewhat abundant in most samples. However the statement is not conclusive, and the taste and odor problem in Fremont Lake could be due to any of the 24 genera associated with taste and odor.

Table 4. Presence or absence of representative taste and odor phytoplankton genera, 1983-84 and 1989

[X, presence; -, absence]

\begin{tabular}{|c|c|c|}
\hline PHYTOPLANKTON GENERA & $1983-84$ & 1989 \\
\hline \multicolumn{3}{|l|}{ BACILLARIOPHYTA } \\
\hline \multicolumn{3}{|l|}{ (Diatoms) } \\
\hline Asterionella & $\mathrm{X}$ & $\mathrm{X}$ \\
\hline Cyclotella & $\mathrm{X}$ & $\mathrm{X}$ \\
\hline Fragilaria & $\mathbf{X}$ & $\mathbf{X}$ \\
\hline Stephanodiscus & - & $\mathrm{X}$ \\
\hline Synedra & $\mathrm{X}$ & $X$ \\
\hline Tabellaria & $\mathrm{x}$ & $\mathrm{x}$ \\
\hline \multicolumn{3}{|l|}{ CHLOROPHYTA (Green algae) } \\
\hline Chlamydomonas & $X$ & $\mathbf{X}$ \\
\hline Cosmarium & $\mathrm{X}$ & $\mathrm{X}$ \\
\hline Dictyosphaerium & $\mathrm{X}$ & - \\
\hline Gloeocystis & - & $\mathrm{X}$ \\
\hline Scenedesmus & $\mathrm{X}$ & - \\
\hline Volvox & $\mathrm{x}$ & - \\
\hline \multicolumn{3}{|l|}{ CHRYSOPHYTA } \\
\hline \multicolumn{3}{|l|}{ (Golden-brown algae) } \\
\hline Dinobryon & $\mathrm{X}$ & $\mathbf{X}$ \\
\hline Mallomonas & $\mathrm{X}$ & $\mathrm{X}$ \\
\hline Uroglena & - & $\mathrm{X}$ \\
\hline \multicolumn{3}{|l|}{ CYANOPHYTA } \\
\hline \multicolumn{3}{|l|}{ (Blue-green algae) } \\
\hline Anabaena & $\mathrm{X}$ & $\mathbf{X}$ \\
\hline Aphanocapsa & $\mathrm{x}$ & $\mathrm{X}$ \\
\hline Aphanothece & $\mathrm{X}$ & $\mathrm{X}$ \\
\hline Chroococcus & $\mathrm{X}$ & $X$ \\
\hline Gomphosphaeria & $\mathrm{X}$ & - \\
\hline Microcystis & - & $X$ \\
\hline
\end{tabular}

Table 4. Presence or absence of representative taste and odor phytoplankton genera, 1983-84 and 1989--Continued

\begin{tabular}{|c|c|c|}
\hline PHYTOPLANKTON GENERA & $1983-84$ & 1989 \\
\hline $\begin{array}{l}\text { Oscillatoria } \\
\text { PYRROPHYTA (Dinoflagelates) }\end{array}$ & $\mathbf{X}$ & $\overline{\mathbf{X}}$ \\
\hline $\begin{array}{l}\text { Peridinium } \\
\text { CRYPTOPHYTA (Cryptomonads) }\end{array}$ & $\mathbf{X}$ & - \\
\hline Cryptomonas & $\mathbf{X}$ & $\mathbf{X}$ \\
\hline
\end{tabular}

\section{DISCUSSION}

Fremont Lake is a large oligotrophic lake that has undergone little physical and chemical change since the study of Rickert and Leopold (1972). This study was concerned with the phytoplankton of the lake with the goal of documenting present phytoplankton species and abundance and determining if there are trends towards enrichment of the lake. An additional goal was to document taste and odor phytoplankton in the lake and to assess their impact.

Presently (1990), the phytoplankton composition of Fremont Lake consists of those species that would be expected in a high-altitude, dilute-solution lake. There is no indication of enrichment, although the blue-green algal species presently are worthy of observance. Phytoplankton concentrations generally are low, with higher concentrations of particular species occurring from time to time. Nutrient concentrations are low, but should be measured using modem analytical techniques. If phytoplankton cause the taste and odor problem in the town of Pinedale water supply, it probably is due to one or more of the genera of phytoplankton associated with taste and odor problems listed in table 4. Tabellaria was the most abundant of the taste and odor genera during the sampling periods, but other genera may have been more abundant at other times.

\section{SELECTED REFERENCES}

American Public Health Association, American Water Works Association, and Water Pollution Control Federation, 1985, Standard methods for the examination of water and wastewater (16th ed.): Washington, D.C., American Public Health Association, 1,268 p.

Britton, L.J., and Greeson, P.E., eds., 1989, Methods for collection and analysis of aquatic biological and microbiological samples: U.S. Geological Survey Techniques of WaterResources Investigations, book 5, chap. A4, 363 p.

Carlson, R.E., 1977, A trophic state index for lakes: Limnology and Oceanography, v. 22, p. 361-369.

Emmett, W.W., and Averett, R.C., 1989, Fremont Lake, Wyoming--some aspects of the inflow of water and sediment: U.S. Geological Survey Water-Resources Investigations Report 88-4021, 25 p. 
Grabowski, J.J., 1982, Evaluation of limnological parameters as related to the success of Mysis relicta introductions: Laramie, University of Wyoming, Water Resources Research Institute Series No. 85, 164 p.

Horne, A.J., 1977, Nitrogen fixation--a review of the phenomenon as a polluting process: Progress in Water Technology, v. 8, p. 357-372.

Leopold, L.B., 1980, Bathymetry and temperature of some glacial lakes in Wyoming: Proceedings of the National Academy of Sciences, v. 77, no. 4, p. 1754-1758.

Lund, J.W.G., 1965, The ecology of freshwater plankton: Biological Review, v. 40, p. 231-293.

1972, Eutrophication: Proceedings of the Royal Society of London, Series B, v. 1809, p. 371-382.

Palmer, C.M., 1962, Algae in water supplies: U.S. Department of Health, Education and Welfare, Public Health Service, publication No. 657, $88 \mathrm{p}$.
Peterson, D.A., Averett, R.C., and Mora, K.L., 1987, Water quality of Fremont and New Fork Lakes, western Wyoming--a progress report: U.S. Geological Survey Water-Resources Investigations Report 86-4016, 55 p.

Prescott, G.W., 1974, How to know the freshwater algae: Dubuque, lowa, Wm. C. Brown Company, 348 p.

Reid, G.K., and Wood, R.D., 1976, Ecology of inland waters and estuaries ( $2 \mathrm{~d}$ ed.): New York, Van Nostrand Co., $485 \mathrm{p}$.

Rickert, D.A., and Leopold, L.B., 1972, Fremont Lake Wyoming--preliminary survey of a large mountain lake: U.S. Geological Survey Professional Paper 800-D, p. D173-D188.

Smith, G.M., 1950, The freshwater algae of the United States: New York, McGraw-Hill, 719 p.

Trainor, F.R., 1978, Introductory phycology: New York, John Wiley and Sons, $525 \mathrm{p}$.

Wetzel, R.G., 1983, Limnology (2d ed.): New York, Saunders College Publishing, 767 p. (plus references). 